\title{
SURVEY OF PILEDRIVER RESULTS \\ AND PRELIMINARY INTERPRETATION OF THREE \\ POSTSHOT CORES IN AND NEAR THE CAVITY
}

I. Y. Borg

April 29, 1970

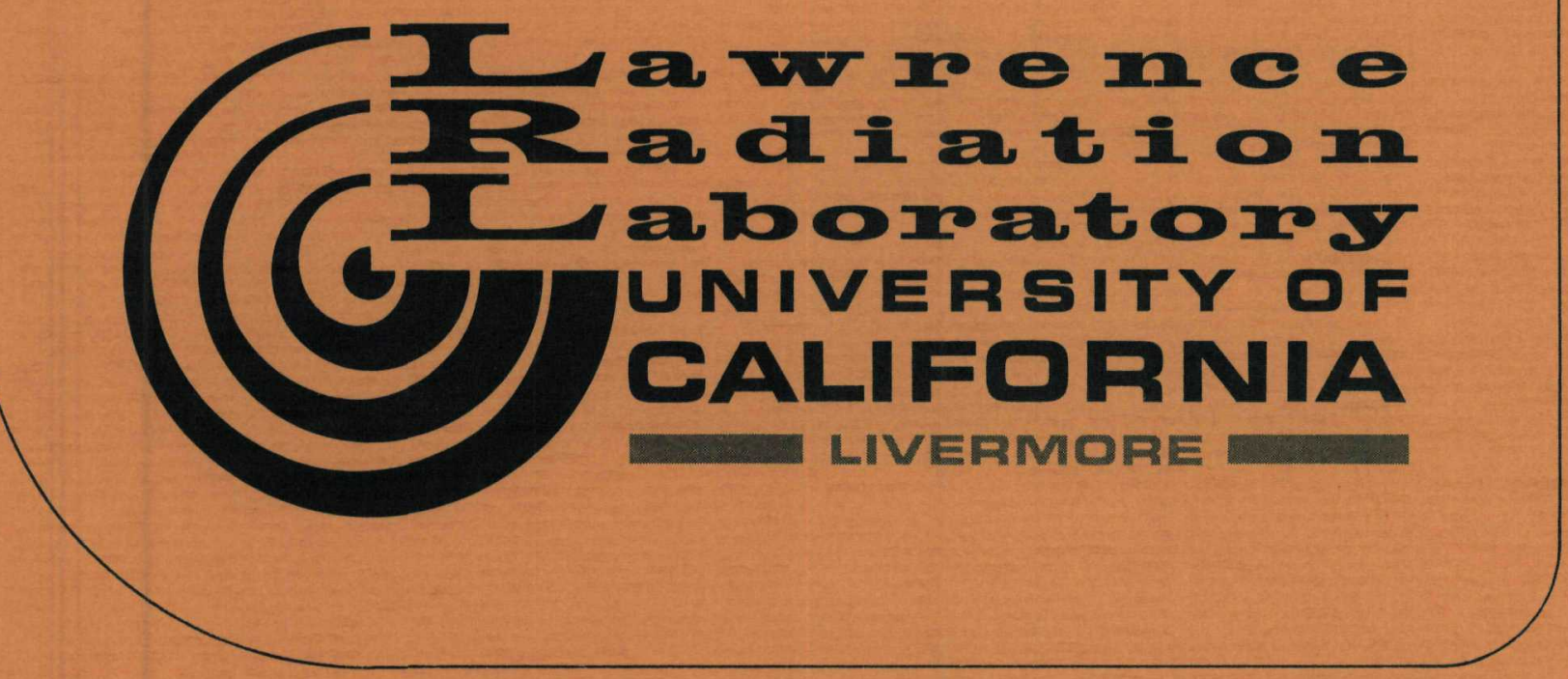

THIS DOCUMENT CONFIRMED AS

UNCLASSIFIED

DIVISION OF CLASSIFICATION

\begin{tabular}{l} 
BY QHKafum \\
DATE $\quad$ \% $/ 27 / 70$ \\
\hline
\end{tabular} 


\section{DISCLAIMER}

This report was prepared as an account of work sponsored by an agency of the United States Government. Neither the United States Government nor any agency Thereof, nor any of their employees, makes any warranty, express or implied, or assumes any legal liability or responsibility for the accuracy, completeness, or usefulness of any information, apparatus, product, or process disclosed, or represents that its use would not infringe privately owned rights. Reference herein to any specific commercial product, process, or service by trade name, trademark, manufacturer, or otherwise does not necessarily constitute or imply its endorsement, recommendation, or favoring by the United States Government or any agency thereof. The views and opinions of authors expressed herein do not necessarily state or reflect those of the United States Government or any agency thereof. 


\section{DISCLAIMER}

Portions of this document may be illegible in electronic image products. Images are produced from the best available original document. 
TID-4500, UC-35

Nuclear Explosions -

Peaceful Applications

Lawionce Fadiation Iaboratory

UNIVERSITY OF CALIFORNIA

LIVERMORE

UCRL- 50865

\section{SURVEY OF PILEDRIVER RESULTS \\ AND PRELIMINARY INTERPRETATION OF THREE POSTSHOT CORES IN AND NEAR THE CAVITY}

I. Y. Borg

LEGAL NOTICE

This report was prepared as an account of work sponsored by the United States Government. Neither the United States nor the United States Atomic Energy Commission, nor any of their employees, nor any of their contractors, subcontractors, or their employees, makes any warranty, express or implied, or assumes any

legal liability or responsibility for the accuracy, com-

pleteness or usefulness of any information, apparatus, product or process disclosed, or represents that its use would not infringe privately owned rights. 
•

. 
Abstract

Introduction

Description of the Piledriver Site In Situ Stress Measurements

Displacements

Cavity Size Measurements and Predictions

Preexisting Joints and Fractures

Orientation

Influence on Chimney Shape

Fracturing Produced by the Explosion

Postshot Core Drilling to Study Fracturing . . . . . . . . . $\quad 15$

Amount of Macroscopic Fracturing in the Cores $\quad$ • . . . . . $\quad$ • 21

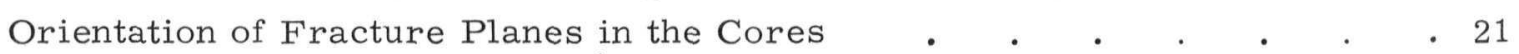

Implications of Observed Orientations of Fracture Planes $\quad$ • $\quad . \quad$ • 29

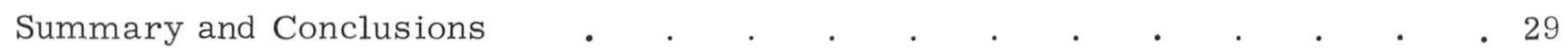

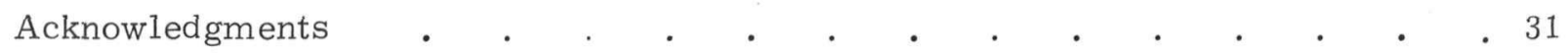

Appendix 1. Summary of Projects Included in Piledriver Event . . $\quad$. 32

Appendix 2. Chemical Analyses of Samples from Climax Stock . • . . 34

Appendix 3. Modal Analyses of Mineral Content of Samples from Climax Stock . 36

Appendix 4. Porosity, Density, Water Content, and Sonic Velocity

of Samples from Climax Stock at Various Depths. . . . . . . 37

Appendix 5. Stress Measurements from Piledriver Event . . . . . 39

Appendix 6. Strikes and Dips of Preexisting Joint Sets in the CR Drift . • 40

Appendix 7. Photographs of Cores from Hole U-15.01 PS-1 • . . . . 42

Appendix 8. Photographs of Cores from Hole U-15.01 PS-2 . . . . . 53

Appendix 9. Photographs of Cores from Hole U-15.01 PS-3 . . . . . . 58

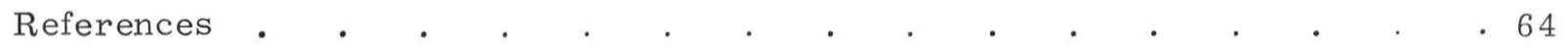




\title{
SURVEY OF PILEDRIVER RESULTS AND PRELIMINARY INTERPRETATION OF THREE POSTSHOT CORES IN AND NEAR THE CAVITY
}

\begin{abstract}
A summary of measured data collected by numerous agencies cooperating in the Piledriver event $(61 \pm 10 \mathrm{kt}$ in granodiorite, June 2, 1966) is presented together with calculations based on empirical relations deduced from past events in comparable media. Highlights include the following: peak measured radial pressure experienced by surviving rock was $250-270 \mathrm{~kb}$; at $350 \mathrm{~m}$ from the present cavity edge the radial pressure was $<1 \mathrm{~kb}$; radius of the spherical mass of rock vaporized and melted is $15.6 \mathrm{~m}$; the displacement ("heave") is at a maximum at the cavity edge, $24.5 \mathrm{~m}$, and is less than $0.3 \mathrm{~m}$ at $305 \mathrm{~m}$ from the shot point; measured cavity radius is $40.1 \mathrm{~m}$. Of nine relations that have been proposed to predict cavity radius, five result in radii accurate to $\varangle 3.5 \%$. The remainder are off by about $10-18 \%$.

The shape of the Piledriver chimney is known to depart from that of a cylinder with semihemispherical ends. The $13^{\circ}$ cant measured on the SW wall is probably due to collapse and shearing along preexisting planes of weakness which are part of a regional pattern. By analogy with information from the Hardhat chimney exploration in the same igneous body, the Piledriver chimney may in fact have nearly vertical walls on the unexplored NE side

and thus be axially asymmetric. It is possible that further exploration in the Hardhat chimney would reveal a similar asymmetry.

Three postshot recovered cores (U-15.01 PS-1, -2, -3) have been examined on a gross scale prior to extensive detailed sampling for laboratory tests. The positions of injected glass seams, radioactivity, and shear zones were recorded. The orientation of several thousand core fractures was measured with respect to the core axes and distance from the shot point. Although cores and the fractures they contain cannot be uniquely oriented in space, it can be demonstrated that the fractures are not randomly oriented with respect to the shot point and that they have attitudes consistent with failure along the four major and several minor preexisting fracture and/or joint sets. In general their positions are not consistent with radial or tangential fracturing. The test for shear failure cannot be applied satisfactorily to the data at hand. Taking all observations into account, phenomena related to failure of rock in the Piledriver event are closely related to preexisting weaknesses and inhomogeneities.
\end{abstract}




\section{Introduction}

The Piledriver event in 1966 was a 61-kt contained nuclear shot in granodiorite. Of interest to the Plowshare program were the effects produced in the medium by the explosion - for example, cavity size, chimney shape and dimensions, displacements, pressures, and so forth. Table 1 summarizes these aspects of the experiment and the principal results obtained to date.

The purpose of this report is twofold: (1) to compile information pertinent to the study of the effects of the Piledriver nuclear explosion in granodiorite, and (2) to describe macroscopic phenomena observed in three recovered postshot cores.

The compiled information constitutes background material for further study of permeability, compressibility, phase transformations, micro-deformational features, etc. It derives from technical letters and reports of various agencies that have been involved in both the Hardhat and Piledriver experiments: e.g., USGS, NTS, DASA, U.S. Army Corp of Engineers, and their subcontractors. The data are presented in abbreviated form, primarily as appendices. Because the number of reports covering Piledriver effects is already quite large and because they infrequently refer to each other, it was decided to cite all sources. In this way it is hoped that this summary will be useful to the various groups working on postshot effects. Interested parties can thus readily locate additional information or details if desired.

The second aim was to retrieve as much information as possible from the cores before they were subjected to

Table 1. Summary of principal data on Piledriver event.

\begin{tabular}{|c|c|}
\hline Date shot & June 2, 1966. \\
\hline Yield & $\begin{array}{l}61 \pm 10 \mathrm{kt} \text {, based on LASL determination on injected glass } \\
\text { encountered in reentry tunnel } 300 \mathrm{ft} \text { from shot point, } 14 \text { months } \\
\text { after shot. } 1,2\end{array}$ \\
\hline Shot depth & $1518 \mathrm{ft}(462.8 \mathrm{~m})$ below surface (3572 ft above MSL). \\
\hline Cavity radius & $\begin{array}{l}131.5 \mathrm{ft}(40.1 \mathrm{~m}) \text {, measured in drill hole which inter sected } \\
\text { cavity wall at a point } 34 \mathrm{ft}(10.4 \mathrm{~m}) \text { below shot level. }\end{array}$ \\
\hline Chimney height & $910 \mathrm{ft}(277.4 \mathrm{~m})$ above shot level. ${ }^{2}$ \\
\hline Chimney width & $\begin{array}{l}160 \mathrm{ft}(48.8 \mathrm{~m}) \text {, measured in reentry tunnel at a point } 103 \mathrm{ft} \\
(31.4 \mathrm{~m}) \text { above shot level. }\end{array}$ \\
\hline Chimney volume & $6.69 \times 10^{7} \mathrm{ft}^{3}\left(19.0 \times 10^{5} \mathrm{~m}^{3}\right)$, or $>29.4 \mathrm{r}^{3}$ \\
\hline $\begin{array}{l}\text { Pressure of over- } \\
\text { burden at shot point }\end{array}$ & $\begin{array}{l}1751 \mathrm{psi}(121 \mathrm{bars}) \text {, calculated on basis of average density of } \\
2.66 \mathrm{~g} / \mathrm{cc} \text {. }\end{array}$ \\
\hline Apical voida & $2 \mathrm{ft}$ high. ${ }^{2}$ \\
\hline $\begin{array}{l}\text { Time of cavity } \\
\text { collapse }\end{array}$ & Within 14 sec after the shot. ${ }^{1}$ \\
\hline $\begin{array}{l}\text { Maximum vertical } \\
\text { extent of increased } \\
\text { permeability }\end{array}$ & $1032 \pm 36 \mathrm{ft}(314.6 \pm 11.0 \mathrm{~m})^{2}$ above shot level. \\
\hline
\end{tabular}

\footnotetext{
${ }^{a}$ Empty space between top of chimney fill material and chimney ceiling.
} 
extensive sampling. To this end all three cores were photographed in their entirety and the photographs are reproduced here. The attitudes of all throughgoing fractures in the cores $(>2000)$ were determined with respect to the core axes. Positions of radioactive glasses, shear zones, and petrological discontinuities were noted.

\section{Description of the Piledriver Site}

Both the Hardhat and Piledriver experiments were carried out within the granitic Climax stock of Area 15, NTS (Figs. 1 and 2). In both instances a heavily in- strumented underground tunnel/drift complex was designed to monitor shock phenomena. Names of the projects, outside cooperating agencies, principal

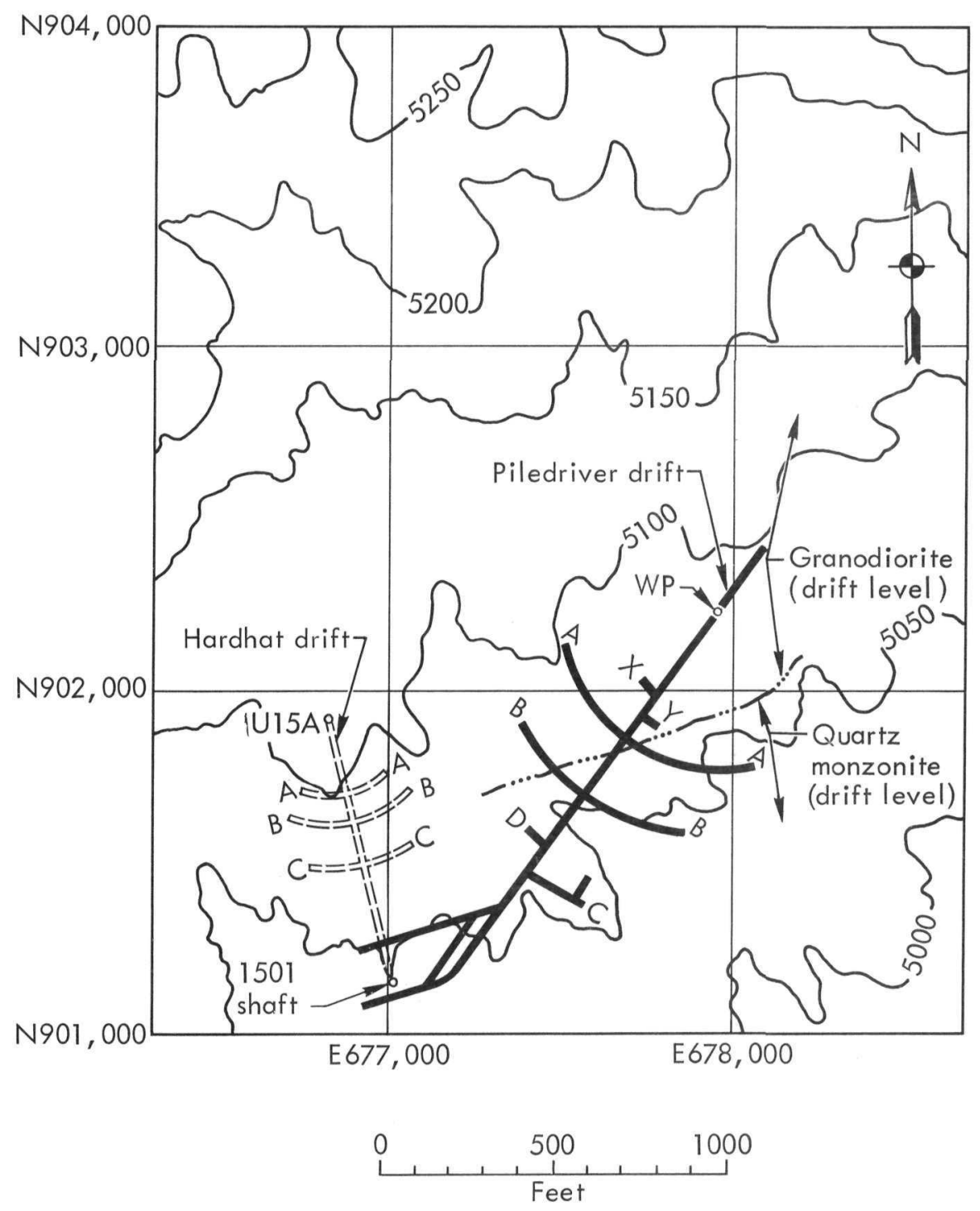

Fig. 1. Piledriver and Hardhat sites in Area 15, NTS. ${ }^{4}$ Contours show surface elevation in feet above sea level. WP marks shot point. 


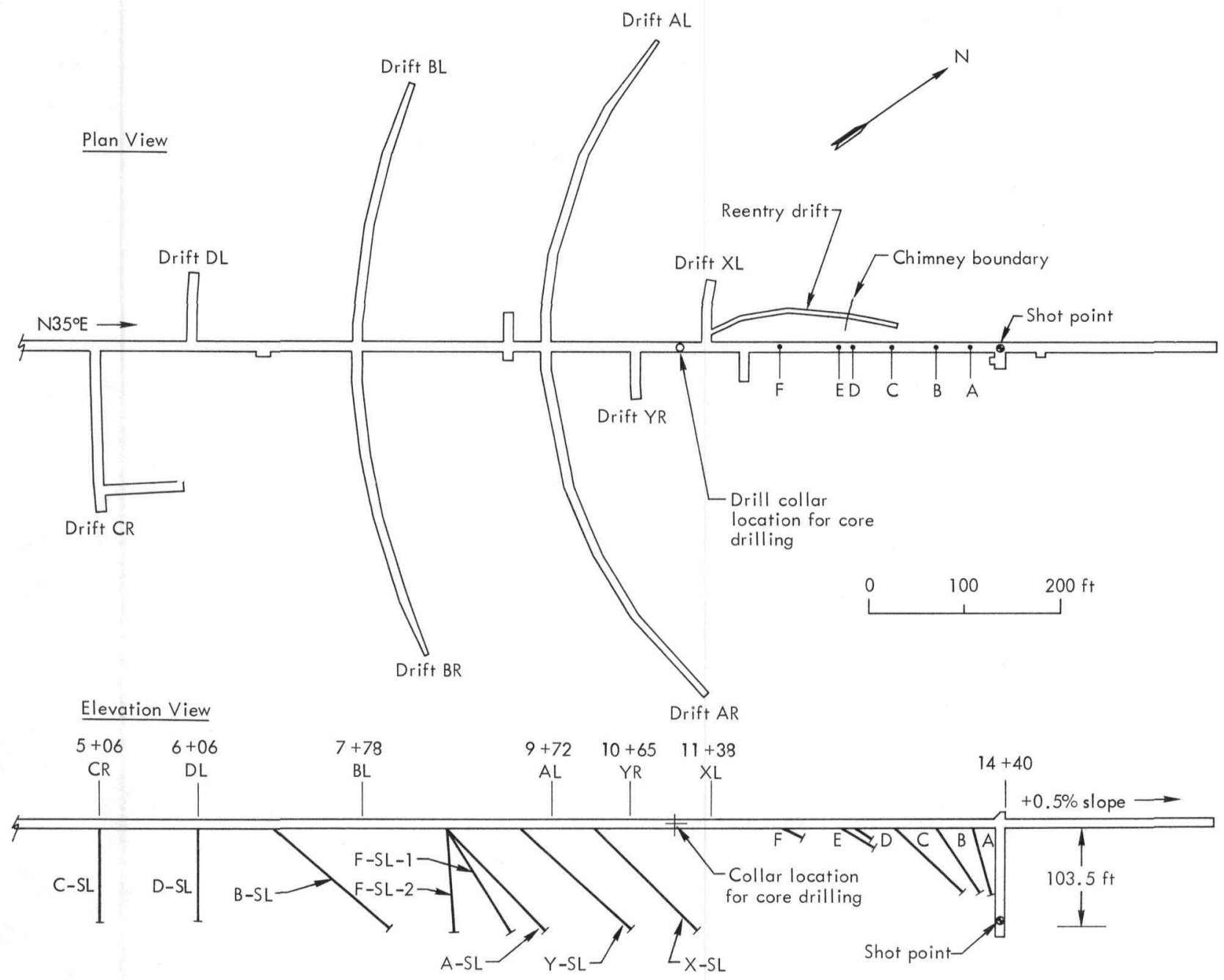

Fig. 2. Piledriver tunnel and drift complex, showing locations of instrumented boreholes at shot time. Stations indicated on Elevation (e.g., 5+06) are referenced to 15.01 shaft $(0+00)$ which is off diagram. (Modified from drawing by $\mathrm{K}$. Willits, Fenix and Scisson, Inc., Project Engineer, 1968, Piledriver Project Sta 15.01, Drawing No. MER-M2 14d-1501, USAEC Nevada Operations Office.)

investigators, and report numbers for the Piledriver event are listed in Appendix 1.

The area of the Climax stock exposed at the surface is 1.3 square miles; however, the rock mass broadens to a diameter of 6 miles at a depth of $13,000 \mathrm{ft} .^{5}$ Adjacent marble, tactite, and sedimentary sequences are well removed from the Piledriver shot point. The stock consists of two petrological types: granodiorite and a younger porphyritic quartz monzonite $(230 \pm 25$ million years $) .{ }^{6}$ Figure 1 shows the indurated, nearly vertical contact between the two. Although much of the instrumentation surrounding both Hardhat and Piledriver was placed in the quartz monzonite portion of the intrusive, the shot points are located well within the granodiorite. Similarly the three postshot Piledriver holes were cored within the granodiorite.

The two igneous rock types are differentiated on the basis of large, pink $\mathrm{K}$-feldspar crystals (up to $5 \mathrm{~cm}$ ) which occur in the quartz monzonite but not in 
the granodiorite. The two rocks are nonetheless similar in chemical composition. Chemical analyses of nine samples are given in Appendix 2. Modal analyses of the volume occupied by the various mineral constituents in a large number of samples (Appendix 3) suggest that there is a wider variation of rock types within the stock than is indicated by the chemical analyses. While it is possible that the chemical analyses available are not representative of the whole stock, it seems more likely that the modal analyses reflect sampling problems connected with the medium coarse grained (1-4 $\mathrm{mm}$ ), sometimes porphyritic texture of the rocks. Initial porosity, bulk grain and powder densities, water content of pores, and sonic velocities are given in Appendix 4 for 26 samples from the U-15a preshot borehole at the Hardhat site (Fig. 1).
The amount of water in the stock is of considerable importance in the interpretation of shock effects. The $\sim 1 \mathrm{wt} \%$ $\mathrm{H}_{2} \mathrm{O}$ recorded in chemical analyses (Appendix 2) is so-called combined water: $\mathrm{H}_{2} \mathrm{O}$ in the form of $(\mathrm{OH})^{-}$tied to hydrous phases such as micas, hornblende, sphene, and alteration products. Another $2 \%$ is estimated to be localized in small scale fractures and pores. 7 The device was emplaced below the water table which is

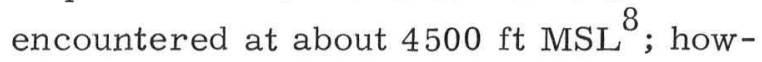
ever, perched water was encountered at variable depths (80-687 ft) during preshot drilling and tunneling operations, suggesting that it is localized by the major fracture and shear zones. ${ }^{7}$ During emplacement of the Piledriver device a local saturated shear zone was encountered which gave rise to substantial downhole flow. 9 


\section{In Situ Stress Measurements}

In addition to instrumentation in the drifts and associated slant holes, 10 five close-in radial bore holes were fitted with stress gages ${ }^{11,12}$ (Fig. 2, holes $\mathrm{A}-\mathrm{F}$ ) by outside contracting agencies. The group from Illinois Institute of Technology used electrolytic chamber gages $\left(\mathrm{CCl}_{4}\right.$, paraffin, and $\mathrm{NH}_{4} \mathrm{OH}$ ); the group from Stanford Research Institute used manganin gages, many of which failed before arrival of the peak radial stress. Data from all reliable gages are plotted in Fig. 3 as a function of distance from the shot point. Also included are peak radial stresses calculated from peak particle velocities. ${ }^{10}$ In at least one instance the calculated stress $(3.9 \mathrm{~kb})$ is higher than the observed peak stress $(1.2 \mathrm{~kb})$ at that point. ${ }^{10}$ In this case calculated stress is believed to be more reliable. Stress data at various stations are included in Appendix 5. Comparable calculated data (SOC code) have been given by Cherry and Rapp. ${ }^{13}$

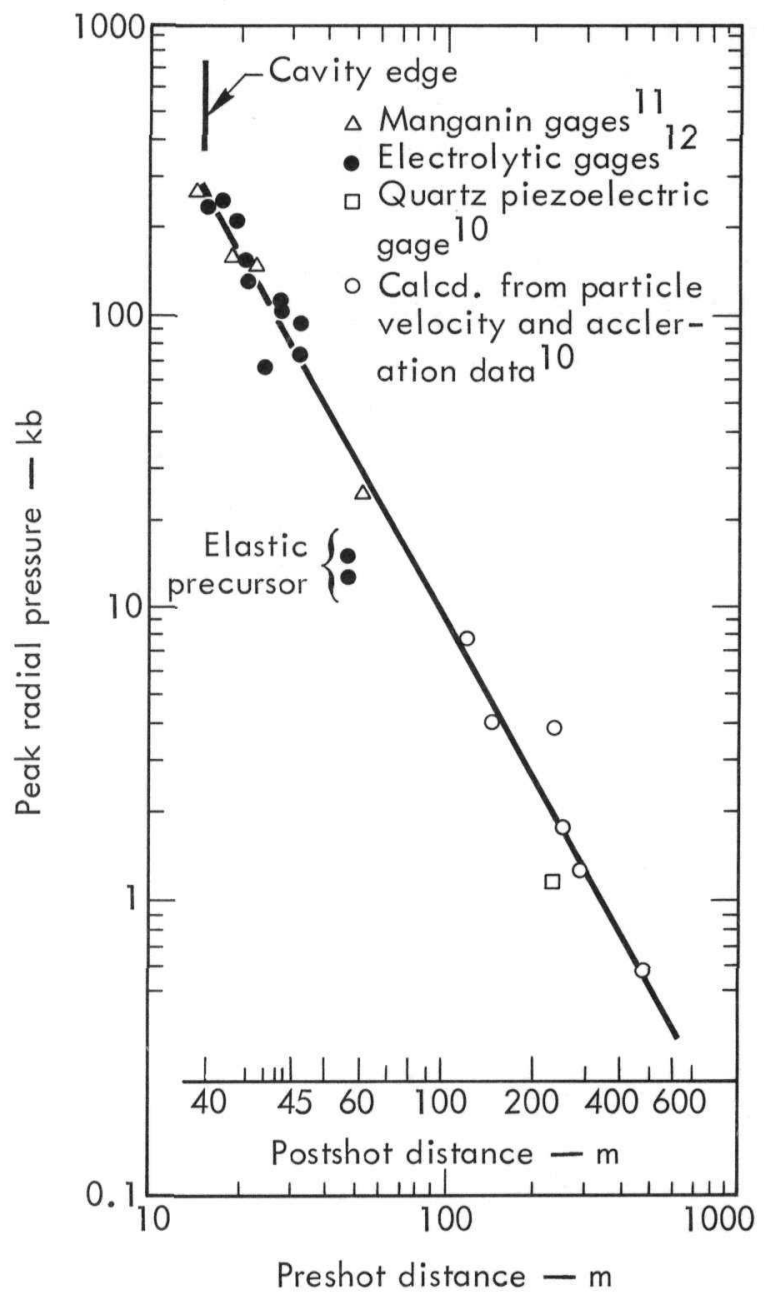

Fig. 3. Measured peak radial stress vs pre- and post-shot distance from Piledriver shot point.

\section{Displacements}

The expansion and heave of the cavity following passage of the main shock wave result in displacements of the surrounding rock which diminish in magnitude with distance from the shot point. In order to correlate data such as peak pressures measured within $100 \mathrm{msec}$ of the time of detonation with observed phenomena in postshot cores and reentered drifts, an estimate of the real displacements must be made. There are numerous ways to do this. One way is to compare positions of surviving surveyed markers in the access tunnel and drifts before and after. This is somewhat unsatisfactory because the portions of the tunnel and drifts have undergone local gross movement on preexisting joints and faults.

Yet another guide to displacements is the so-called "residual radial displacement" 
calculated by single integration of particle velocity or double integration of acceleration curves. Displacements so calculated are strongly affected by base line errors in the initial data and characteristically show great scatter (see Fig. 2.3, Ref.14).

Data of these sorts are plotted as a function of preshot distance in Fig. 4 together with displacements calculated from the SOC code. ${ }^{13}$ Also plotted is a calculated point based on the difference between the observed cavity radius and the radius of melted and vaporized rock. It is assumed that the cavity wall which was intersected below the shot point in postshot drilling (core 3 ) is the true boundary between melted and unmelted rock; i.e., has not been affected by late spall. The argument is as follows:

Cavity development is a continuous process, but it is convenient to describe it as a discontinuous process involving shock vaporization, shock melting, and vapor-solid interactions. The latter involve thermal conduction and exothermic condensation of ionized-vaporized elements on solid rock interfaces exposed by gravity removal of the shock-melted zone.

Butkovich $^{19,20}$ has estimated the amount of granitic rock involved in the three types of transformation:

$$
\text { Shock-vaporized } \quad 70 \times 10^{6} \mathrm{~g} / \mathrm{kt}
$$

Shock-melted $350 \times 10^{6} \mathrm{~g} / \mathrm{kt}$

Melted by solid-vapor

interactions

$$
250-300 \times 10^{6} \mathrm{~g} / \mathrm{kt}
$$

The volume of rock affected can be calculated and the radii of the concentric zones determined (Table 2). The difference between the final cavity radius $40.1 \mathrm{~m}$ (131.5 ft) and that of the cavity void calculated above, $15.6 \mathrm{~m}(51.2 \mathrm{ft})$, represents the distance rock at the cavity wall has been transported by gas expansion, $24.5 \mathrm{~m}$ $(80.3 \mathrm{ft})$.

Agreement between measured and calculated displacements is reasonably good where they can be compared, indicating that the SOC calculation can be used to estimate displacements fairly accurately over the whole range. In the linear portions of the displacement-vsdistance curve (elastic regime?), underground displacements are proportional to the inverse of the square of radial distance. A similar relationship was established from permanent particle displacements at depth in the Hardhat and Shoal tests in granite despite greater scatter in the data. 14

Figure 5 and Table 3 show preshot and postshot radial distances from the shot point derived from displacement data for the Piledriver event.

\begin{tabular}{|c|c|c|c|c|c|}
\hline \multirow[b]{2}{*}{ Process } & \multicolumn{2}{|c|}{ Amount of rock affected } & \multicolumn{3}{|c|}{$\begin{array}{l}\text { Zone limits (radial preshot } \\
\text { distance from shot point) }\end{array}$} \\
\hline & Weight $\left(10^{7} \mathrm{~g}\right)$ & Volume $\left(10^{7} \mathrm{cc}\right)$ & Met & ters & Feet \\
\hline Shock vaporization & 427 & 160 & 0 & -7.26 & -23.8 \\
\hline Shock melting & 2135 & 800 & 7.26 & -13.2 & $23.8-43.3$ \\
\hline $\begin{array}{l}\text { Melting by solid- } \\
\text { vapor interactions }\end{array}$ & 1678 & 628 & 13.2 & -15.6 & $43.3-51.2$ \\
\hline
\end{tabular}

Table 2. Calculated amounts of rock vaporized and melted by Piledriver explosion. 


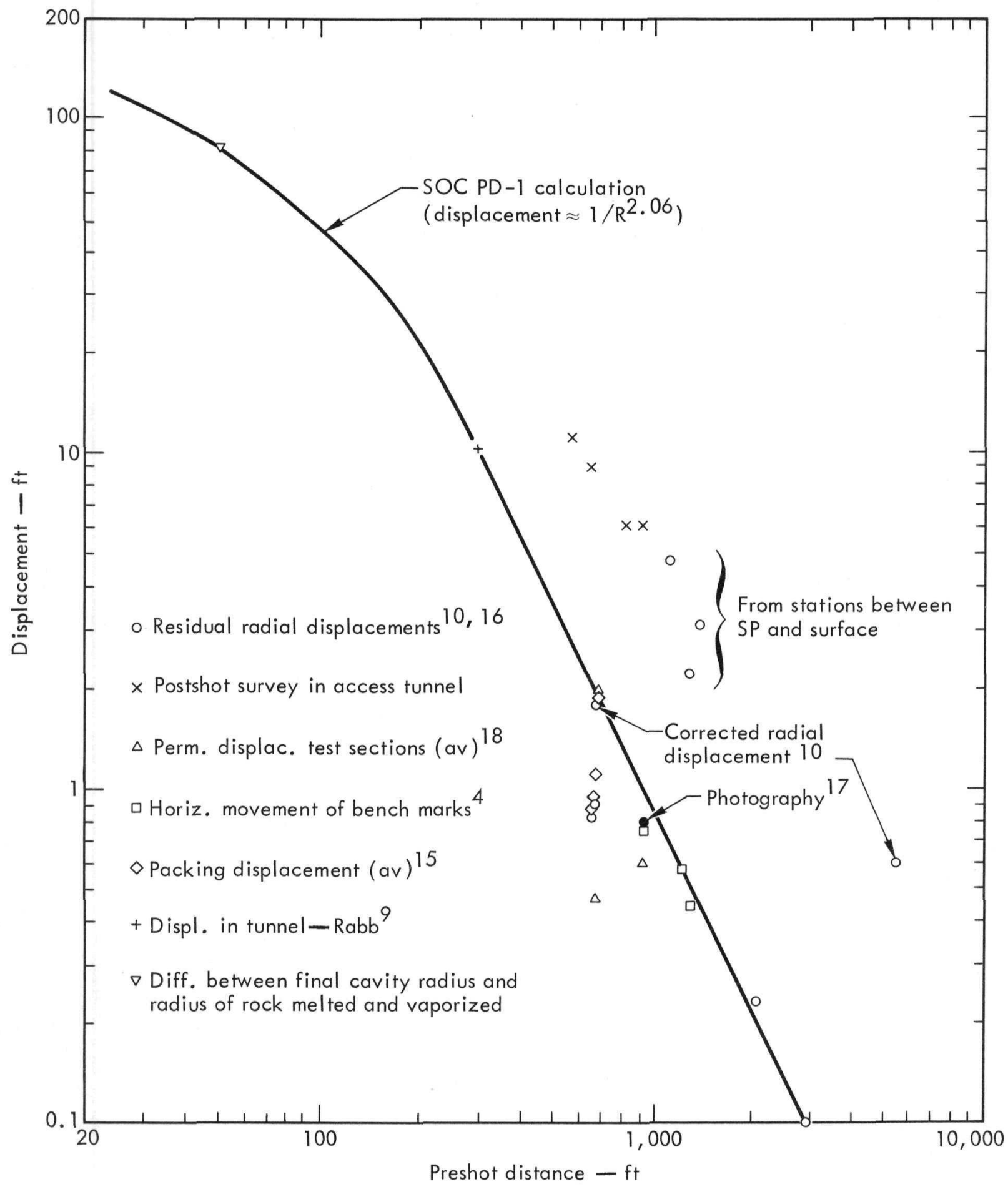

Fig. 4. Measured and calculated displacements as a function of preshot distance from shot point. 
Table 3. Preshot vs postshot radial distances from shot point for displaced rock in Piledriver event.

\begin{tabular}{ccc}
\hline $\begin{array}{c}\text { Preshot } \\
\text { distance } \\
\text { (feet) }\end{array}$ & $\begin{array}{c}\text { Displacement } \\
\text { (feet) }\end{array}$ & $\begin{array}{c}\text { Postshot } \\
\text { distance } \\
\text { (feet) }\end{array}$ \\
\hline 51.2 & 80.3 & 131.5 \\
60 & 73 & 133 \\
70 & 65 & 135 \\
80 & 58 & 138 \\
90 & 53 & 143 \\
100 & 48 & 148 \\
120 & 41 & 161 \\
140 & 35 & 175 \\
160 & 30.5 & 190.5 \\
180 & 26.5 & 206.5 \\
200 & 24 & 224 \\
300 & 10.5 & 310.5 \\
400 & 5.6 & 405.6 \\
500 & 3.6 & 503.6 \\
600 & 2.45 & 602.5 \\
700 & 1.75 & 701.75 \\
1000 & 0.86 & 1000.86 \\
1500 & 0.38 & 1500.38 \\
2000 & 0.205 & 2000.21 \\
3000 & $\sim 0$ & 3000 \\
\hline
\end{tabular}

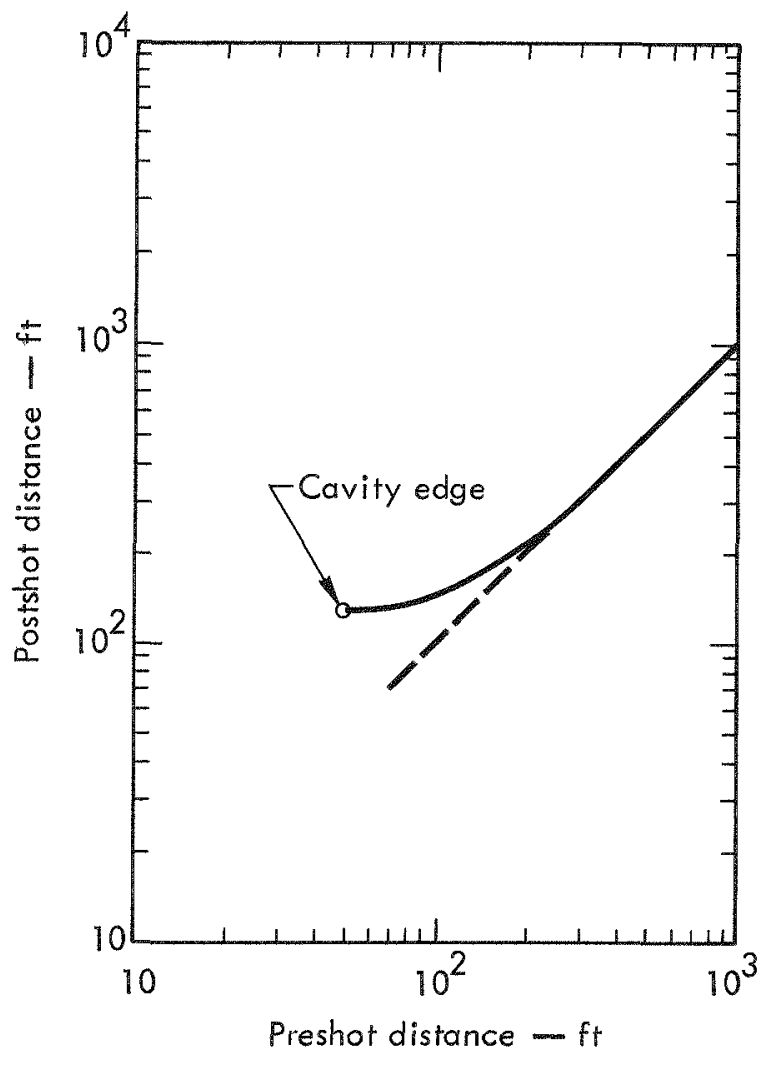

Fig. 5. Displacement of surrounding rock by Piledriver explosion, shown by plot of postshot vs preshot distances from shot point.

\section{Cavity Size Measurements and Predictions}

Prior to postshot drilling of three core holes, various estimates were made of the cavity size to be expected. Table 4 lists these estimates and the methods used to make them. It is of interest to compare these values with the most probable cavity radius of $131.5 \mathrm{ft}(40.1 \mathrm{~m})$ determined by the core drilling. 
Table 4. Predictions of Piledriver cavity radius.

\begin{tabular}{|c|c|c|}
\hline \multicolumn{2}{|c|}{$\begin{array}{l}\text { Predicted } \\
\text { radius }\end{array}$} & \multirow[b]{2}{*}{ Prediction method $^{\mathrm{a}}$} \\
\hline$m$ & $\mathrm{ft}$ & \\
\hline 32.7 & 108 & $\begin{array}{l}\text { SOC calculation assuming constant overburden and no free } \\
\text { surface. } 13\end{array}$ \\
\hline 36.4 & 119 & $r_{c}=21.0\left[\frac{W^{0.306} E^{0.514}}{\rho^{0,244} \mu^{0.576} h^{0.161}}\right]$, Closmann. ${ }^{21}$ \\
\hline 40.1 & 131.5 & $\begin{array}{l}r_{\mathrm{c}}=\frac{\mathrm{CW}^{1 / 3}}{(\mathrm{ph})^{\alpha}} \text { where } \mathrm{C}=103 \text { (granodiorite), } \alpha=0.32\left(2 \% \mathrm{H}_{2} \mathrm{O}\right), \\
\text { Higgins and Butkovich. }\end{array}$ \\
\hline 40.1 & 131.5 & $\begin{array}{l}\text { Measured value, accepted as most probable cavity radius on basis } \\
\text { of gamma and caliper logs of core hole PS-3 which intersected } \\
\text { cavity below level of shot point, Sterrett. }\end{array}$ \\
\hline $40.1^{+}$ & 131.7 & $\begin{array}{l}\text { Assuming adiabatic expansion of cavity gas to twice overburden } \\
\text { pressure (Fig. 2, granite), Chapin. } 23\end{array}$ \\
\hline 40.9 & 134 & $\mathrm{r}_{\mathrm{c}}=\mathrm{C} \frac{\mathrm{W}^{1 / 3}}{(\mathrm{ph})^{1 / 4}}$ where $\mathrm{C}=61.6$ (granite), Boardman. ${ }^{2}$ \\
\hline 41.2 & 135 & $r_{c}=16.3 \frac{W^{0.29} E^{0.62}}{h^{0.11} \rho^{0.24} \mu^{0.67}}$, Heard and Ackerman. ${ }^{24}$ \\
\hline 41.6 & 136 & $\begin{array}{l}\mathrm{r}_{\mathrm{c}}=52 \frac{\alpha^{1 / 3} \mathrm{~W}^{1 / 3}}{(\rho \mathrm{gh}+\mathrm{Cs})^{1 / 3 \gamma}} \text { where } \mathrm{Cs}=30 \text { bars (granite), } \gamma=1.05 \\
\left.\text { (granite with } 2.5 \% \mathrm{H}_{2} \mathrm{O}\right)_{3}^{25} \text { Michaud. }\end{array}$ \\
\hline 44.5 & 146 & $\begin{array}{l}\text { Calculated from void volume of the chimney determined from } \\
\text { chimney pressurization tests, Boardman.2 }\end{array}$ \\
\hline 45.1 & 148 & $\begin{array}{l}r_{c}=\left(3 R^{2} \Delta \sigma\right)^{1 / 3} \text { from corrected residual particle displacements at } \\
\text { slant holes }(668 \mathrm{ft} \text { and } 1543 \mathrm{ft} \text { radial distance), Perrett. } 10\end{array}$ \\
\hline 45.7 & $>150$ & $\begin{array}{l}\text { SOC calculation assuming variable overburden and rarefaction at a } \\
\text { free surface. } 13\end{array}$ \\
\hline
\end{tabular}

$\mathrm{a}_{\text {The symbols used here are defined as follows: }}$

$r_{c}=$ cavity radius,

$\mathrm{W}=$ yield $(k \mathrm{k})$,

$\mathrm{E}=$ Young's modulus $(\mathrm{Mb})$,

$\rho=$ density of rock $(\mathrm{g} / \mathrm{cc})$,

$\mu=$ shear modulus $(\mathrm{Mb})$,

$\mathrm{h}=$ depth of burst $(\mathrm{m})$,

$\alpha$ (Higgins and Butkovich) $=\frac{1}{3} \gamma$. $\gamma=$ coefficient of adiabatic expansion,

$\alpha($ Michaud $)=1.0$ (coefficient related to size of the shot chamber),

$\mathrm{Cs}=$ coefficient related to the "constraints of the structure,"

$R=$ radial range $(m)$,

$\Delta s=$ residual displacement $(\mathrm{m})$.

\section{Preexisting Joints and Fractures}

The Climax stock is everywhere broken by fractures, faults, and shear zones most of which are healed (i.e., cemented by minerals of later origin). The old fractures are conspicuous on all scales, microscopic and macroscopic. Blocks 1 
cubic foot or larger in size are rarely observed without macroscopic fracturing of some sort. ${ }^{27}$ The consensus among geologists who have mapped the fracture systems is that the joints and fractures are short-lived (i.e. terminate within a few yards), and that extrapolation of frequency or attitudes any distance is tenuous. ${ }^{4,27}$ Particle size analysis of Piledriver chimney material indicates that the rubble is somewhat smaller than might be expected from a "typical hard rock." The Hardhat rubble conforms more nearly to the expected distribution. The difference is attributed to the proximity of the Piledriver chimney rubble samples to a preexisting shear zone which now forms the SW chimney wall. ${ }^{9}$ There is no evidence that preshot fractures and joints at the two sites differed significantly in number or spacing.

\section{ORIENTATION}

Preshot fracture and joint studies were carried out by a number of agencies and geologists. $1,4,7,27-30$ As many as eleven sets of joints and fractures have been recorded along the Hardhat 1500 tunnel $^{28}$ and nine sets within approximately $220 \mathrm{ft}$ of the Piledriver CR drift. ${ }^{29}$ (See Appendix 6 for an example of the amount of variation in attitude recorded within the sets.)

Table 5 lists the most prominent sets observed in the stock. Most of the data from the Piledriver site were collected within the quartz monzonite phase of the intrusive (CR and DL drifts and within the tunnel from the access shaft to the Station $9+35$ ); however, there is no evidence suggesting they are oriented differently within the granodiorite surrounding the shot point.

A preexisting fracture-joint set makes a constant angle with the core axis in a given hole, assuming that the bearing of the hole remains constant along its length. These angles are also recorded in Table 5 for all three core holes.

\section{INFLUENCE ON CHIMNEY SHAPE}

Figure 6 contains stereographic projections of the various fracture sets recorded in the Piledriver drifts together with the orientation of the three postshot cores and the main access tunnel. The

Table 5. Orientation of preexisting joints and fractures in the Climax stock.

\begin{tabular}{|c|c|c|c|c|c|c|c|}
\hline & \multicolumn{2}{|c|}{ Hardhat $7,27,28,30$} & \multicolumn{2}{|c|}{ Piledriver 4,29} & \multicolumn{3}{|c|}{ Angle, core axis to fracture set } \\
\hline & Strike & Dip & Strike & Dip & Core 1 & Core 2 & Core 3 \\
\hline \multirow[t]{4}{*}{ Major sets } & $\mathrm{N} 45-53^{\circ} \mathrm{W}$ & $80 \mathrm{SW}-83^{\circ} \mathrm{NE}$ & $\mathrm{N} 50-53^{\circ} \mathrm{W}$ & $29-34^{\circ} \mathrm{NE}$ & $77-83^{\circ}$ & $14-20^{\circ}$ & $84-90^{\circ}$ \\
\hline & $\mathrm{N} 20-36^{\circ} \mathrm{W}$ & $22-30^{\circ} \mathrm{NE}$ & $\mathrm{N} 45-50^{\circ} \mathrm{W}$ & $83 \mathrm{SW}-79^{\circ} \mathrm{NE}$ & $41-59^{\circ}$ & $32-50^{\circ}$ & $30-48^{\circ}$ \\
\hline & $\mathrm{N} 40-62^{\circ} \mathrm{E}$ & $78 \mathrm{SE}-78^{\circ} \mathrm{NW}$ & $\mathrm{N} 73-79^{\circ} \mathrm{W}$ & $78 \mathrm{SW}-79^{\circ} \mathrm{NE}$ & $42-63^{\circ}$ & $35-57^{\circ}$ & $32-83^{\circ}$ \\
\hline & - & - & $\mathrm{N} 36-41^{\circ} \mathrm{E}$ & $73-79^{\circ} \mathrm{SE}$ & $77-83^{\circ}$ & $80-83^{\circ}$ & $80-83^{\circ}$ \\
\hline \multirow[t]{5}{*}{ Minor sets } & $\mathrm{N} 15^{\circ} \mathrm{E}$ & $77 \mathrm{SE}-78^{\circ} \mathrm{NW}$ & $\mathrm{N} 39-49^{\circ} \mathrm{E}$ & $52-59^{\circ} \mathrm{NW}$ & $68^{\circ}$ & $64^{\circ}$ & $74^{\circ}$ \\
\hline & $\mathrm{N} 24-36^{\circ} \mathrm{W}$ & $83 \mathrm{NE}-83^{\circ} \mathrm{SW}$ & $\mathrm{N} 65-67^{\circ} \mathrm{W}$ & 86-87 $\mathrm{NE}$ & $53^{\circ}$ & $40^{\circ}$ & $43^{\circ}$ \\
\hline & N7 5-84 $\mathrm{W}$ & $82 \mathrm{NE}-80^{\circ} \mathrm{SW}$ & $\mathrm{N} 12^{\circ} \mathrm{E}$ & $68^{\circ} \mathrm{NW}$ & $78^{\circ}$ & $39^{\circ}$ & $70^{\circ}$ \\
\hline & $\mathrm{B} 31-34^{\circ} \mathrm{E}$ & $85 \mathrm{NW}-75^{\circ} \mathrm{SE}$ & $\mathrm{N} 28^{\circ} \mathrm{E}$ & $75^{\circ} \mathrm{NW}$ & $38^{\circ}$ & $62^{\circ}$ & $21^{\circ}$ \\
\hline & \multicolumn{2}{|c|}{ And others } & \multicolumn{2}{|c|}{ And others } & & & \\
\hline
\end{tabular}


value of the strike of the fracture sets is an average value. The variation is on the order of $\pm 7^{\circ}$ about this value (Table 5 ).

The range in the value of the dip (shaded areas of Fig. 6(a)) is only approximately known and is probably of the same order of magnitude as that of the strike. Average values for both strike and dip are plotted for minor fracture sets in Fig. 6(b). Also plotted in Fig. 6(a) is a line (point c) joining the two locations at which the chimney was encountered in postshot explorations - in the tunnel and during coring of hole 3 . The line falls near the intersection of the two major steeply dipping fracture sets. Thus one or both of these sets of preexisting fractures probably influenced the spall and chimney shape on the SW side as pointed out by Sterrett. 3

Assuming that the other sets are equally well developed and just as influential in determining chimney shape, one might anticipate the same cup-shape on the NW side of the chimney (Fig. $7(a)$ ). The development of NE and SE walls appears to lack structural control, and they would be expected to be nearly vertical up to the roof. Of the four major fracture systems, the fourth, which dips $31^{\circ} \mathrm{NE}$, is in the best position to affect the shape of the chimney roof, especially on the NE side. It would be expected to expedite collapse of an apical void if one formed. No appreciable void was detected during exploration into the top of the chimney. 2

The Hardhat event (February 15, 1962) occurred approximately $1 / 4$ mile away in the granodiorite of the same (Climax) igneous body. Postshot exploration of the Hardhat chimney (Fig. 7(b)) indicates the walls are nearly vertical, at least in the plane of the sketch which contains all drill holes and the tunnel. If it is assumed that the shape of the Piledriver and Hard-
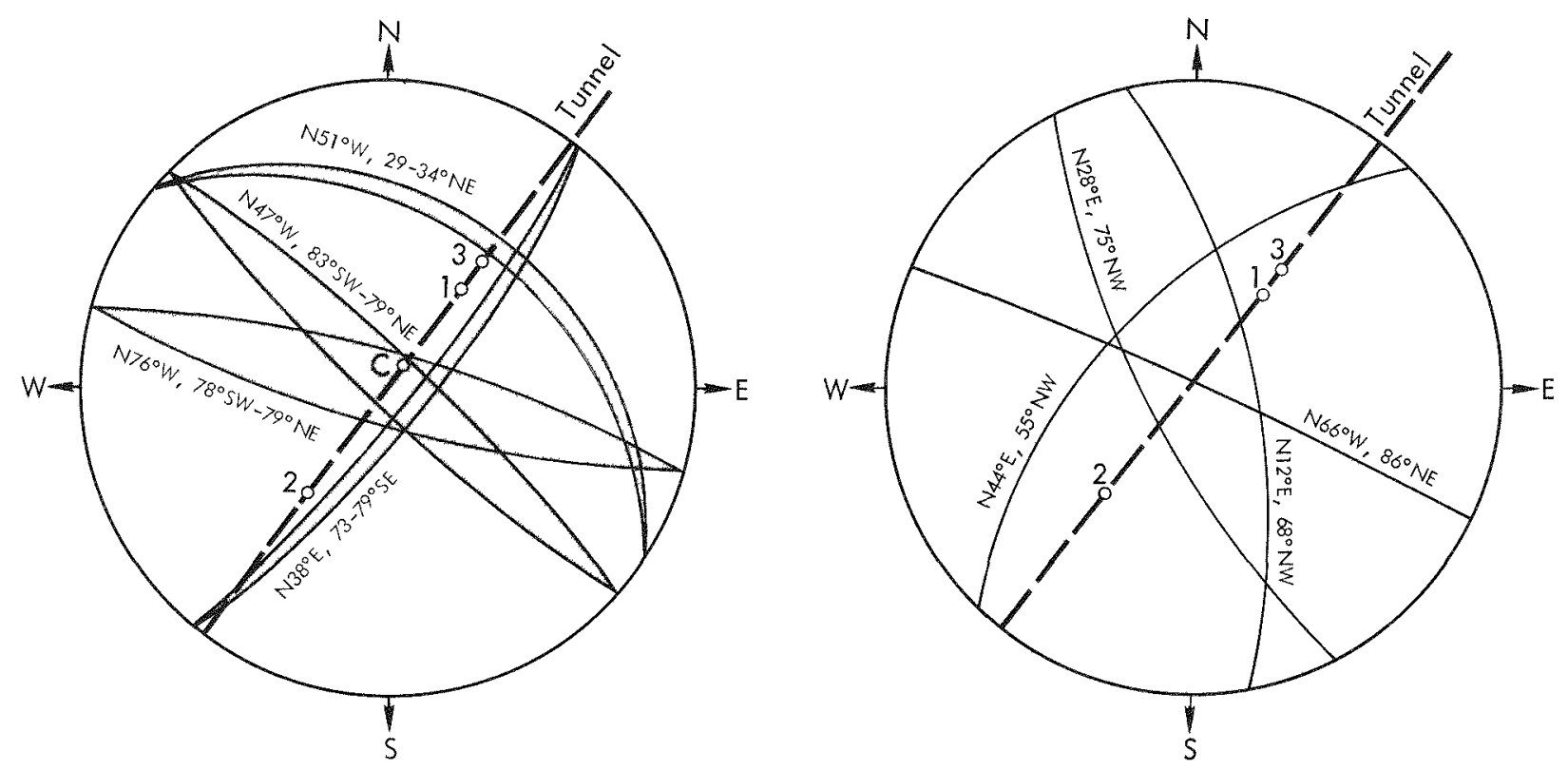

Fig. 6. Stereographic projections of major (a) and minor (b) fracture-joint systems within the Climax Stock. 1,2, and 3 are locations of postshot drill holes: $\mathrm{C}$ is line connecting two points (in tunnel and in core 3) where chimneygranodiorite contact was observed-i.e., a line in the chimney wall. 


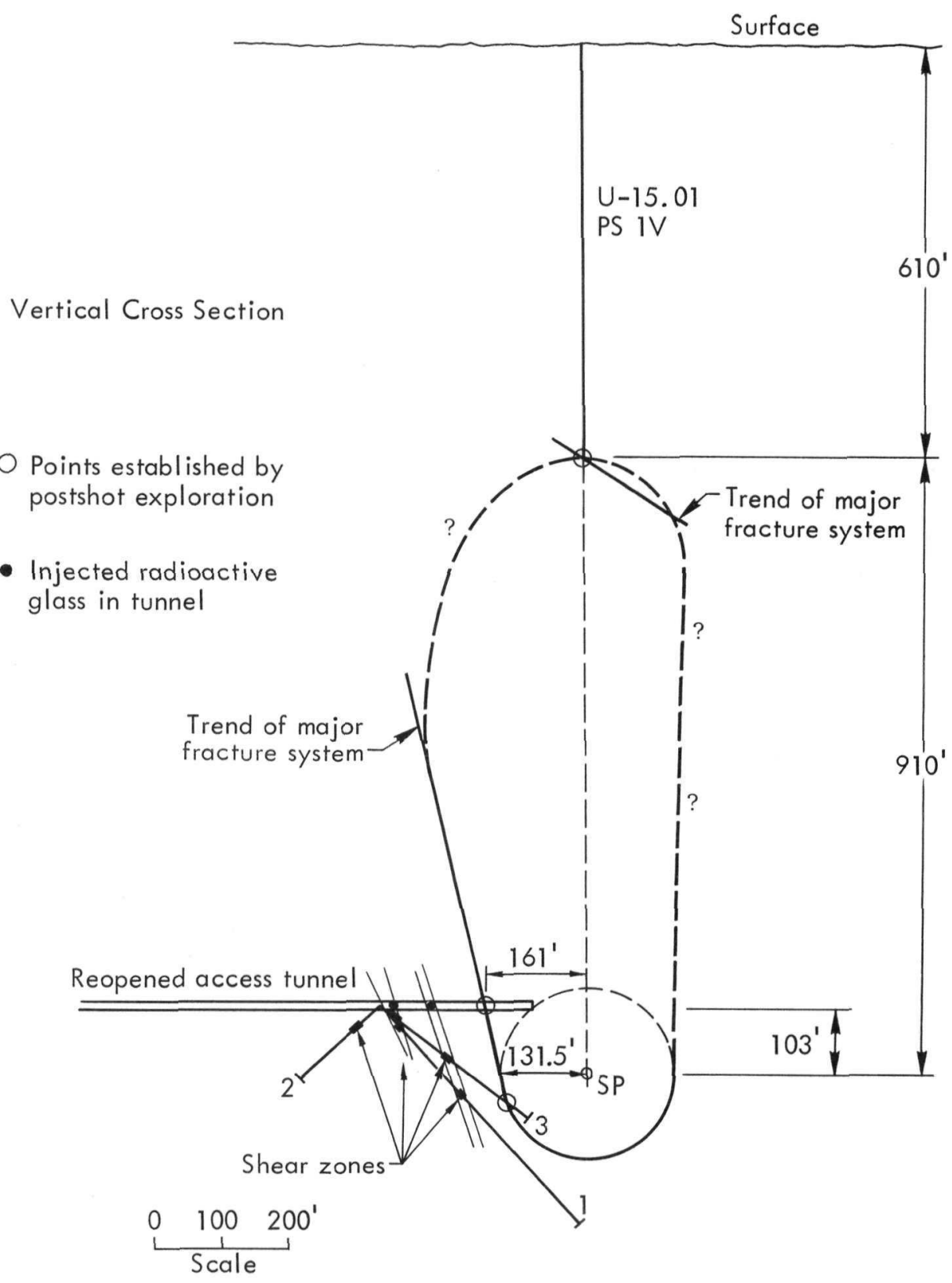

Horizontal Cross Section at Tunnel Level

(a) Piledriver

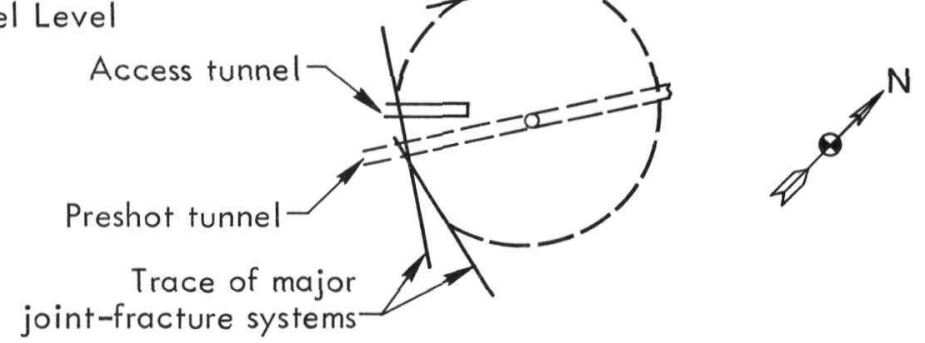

Fig. 7(a). Chimney shape resulting from Piledriver event. 


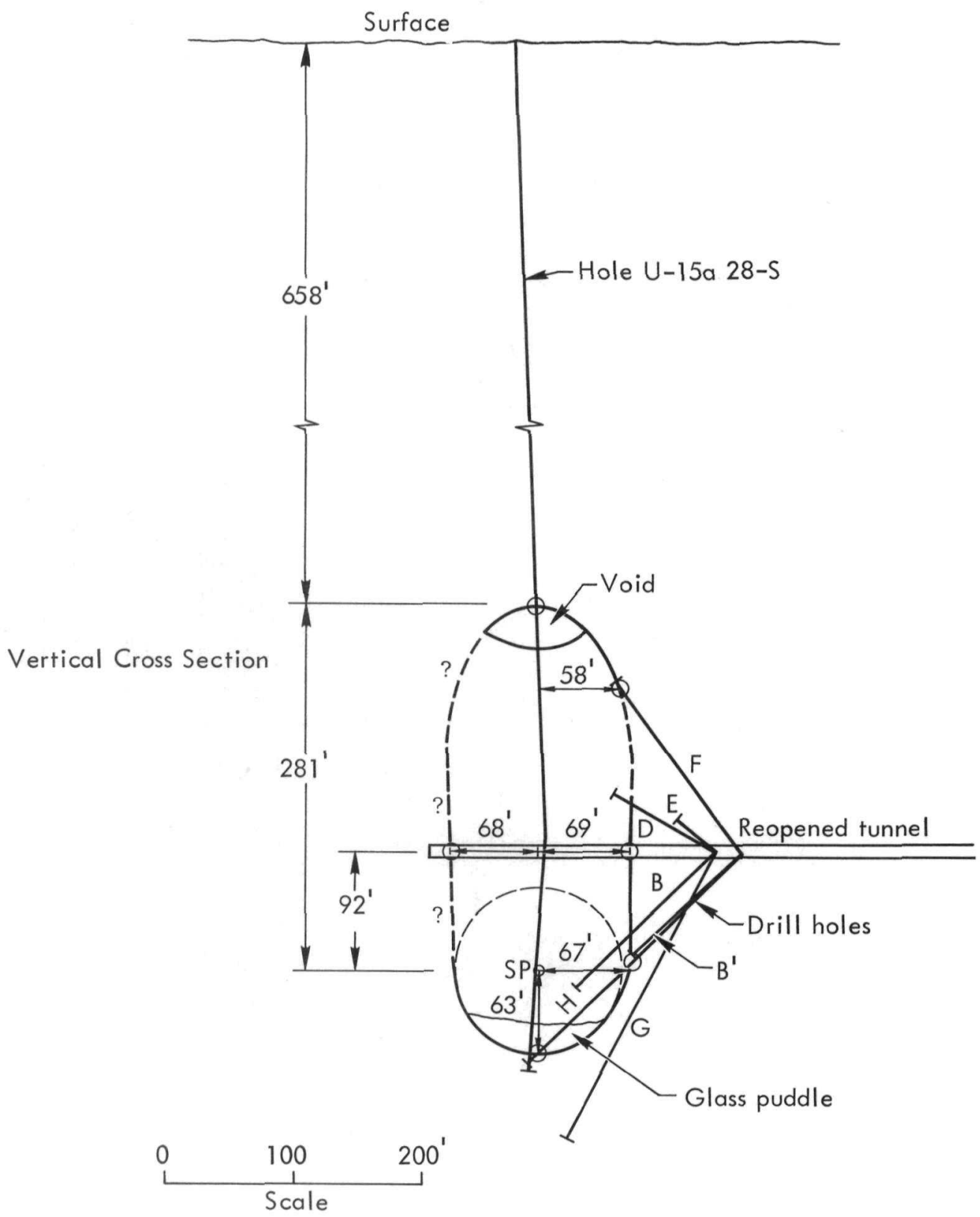

Horizontal Cross Section at Tunnel Level

(b) Hardhat

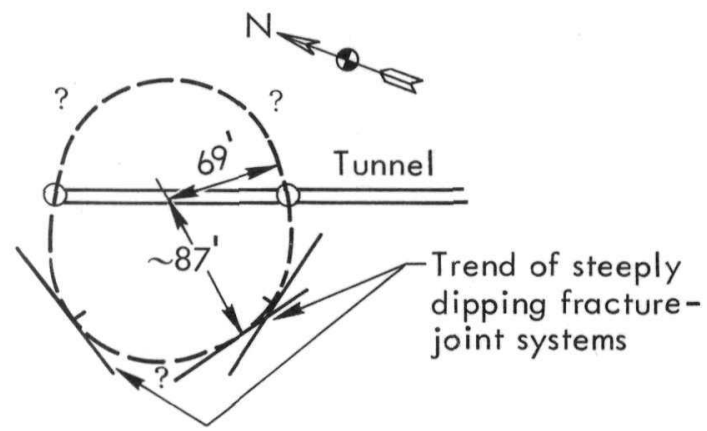

Fig. 7(b). Chimney shape resulting from Hardhat event.

hat chimneys are similar, the only way to reconcile the results of postshot exploration at the two sites is by proposing an axially asymmetric shape. 
Thus by analogy with the Hardhat experience, a cross section with vertical walls may exist in the Piledriver chimney.
Conversely at least one wall of the unexplored portions of the Hardhat chimney may depart from the vertical.

\section{Fracturing Produced by the Explosion}

No one has yet made a thorough study of the attitude of shock-induced fractures in an isotropic medium surrounding an underground explosion source." However, it is generally assumed that their orientations are related to the direction of propagation of the shock wave and that they can be described as radial, tangential, or shear fractures. By analogy with static loading tests, shear fracturing at angles of $25-45^{\circ}$ to the direction of maximum principal stress $\left(\sigma_{1}\right)$ occurs at high mean compressive stresses. This shear fracturing is in large part responsible for the intense fracturing and disaggregation of rock immediately surrounding a cavity produced by a nuclear explosion. At greater distances from the source, compressive failure probably more closely resembles "extension" failure of static tests. 32,33 specifically, breaks occur parallel to the direction of peak pressure which may (but not necessarily) coincide with a radial direction. Rarefaction of the shock at a gross discontinuity-e.g., the surface of a tunnelcan potentially produce fracturing at right angles to this second type, thereby approximating tangentially oriented breaks.

"There have, however, been several investigations of local effects. For example, Houser and Emerick 31 measured the orientation of large-scale "explosion-produced" fractures within a 100 -ft interval of the 1500 tunnel adjacent to the Hardhat chimney.
These fractures are directly related to the passage of the shock wave. At close-in locations another series of fractures develops as a consequence of the later expansion of the cavity formed by melt and vaporization of the rock. This is gross displacement (heave) of adjacent unmelted or unvaporized rock. By analogy with the surface of an expanding balloon, radial breaks are likely.

In practice, fielding of an experiment in an isotropic medium is highly unlikely because of the ubiquitous joints, bedding, layering, etc. of most rocks. In the Piledriver experiment, such preexisting discontinuities have dissipated the peak radial pressure by at least $20 \%$ as judged by the magnitude of the tangential component $^{10}$ of measured pulses. Under such circumstances, it is questionable whether any fracture pattern symmetrically related to the shot point can be recognized. However, it is one of the problems addressed by the core fracture study described later.

\section{POSTSHOT CORE DRILLING TO STUDY FRACTURING}

The drilling of three postshot cores has been described by Sterrett. ${ }^{3} \mathrm{He}$ obtained gamma, caliper, and temperature logs of core 3 which penetrates the cavity, thereby fixing the cavity radius at $r_{c}=131.5 \mathrm{ft}$. All three recovered cores were photographed in their entirety prior to sampling (Appendices 7-9). The 
information noted alongside the individual photographed core boxes derives largely from inspection. "Shear zone" labels were assigned on the basis of the condition of the core, the percent recovery in that interval, and whether there was a loss of drilling fluid circulation at that point. By extrapolation between cores 1 and 3 the trend of the zones so recognized (Fig. $7(\mathrm{a})$ ) can be established as parallel to regional structure. Furthermore, they are parallel to the one line known to be contained by the SW chimney wall.

Core 1 approaches within $160 \mathrm{ft}$ of the shot point. There is a clear disparity in the condition of the core on either side of this point (288 ft slant hole distance).

From the photographs as well as from the amount of core recovered on either side of the point of closest approach, it can be seen that the amount of fracturing at a given distance from the shot point can vary. In this instance there is more fracturing in the vicinity of the chimney walls than in rock more nearly under the cavity void.
Core 3 is in the poorest condition of the three and has the lowest recovery record (Fig. 8). This is primarily due to a change in drilling technique. ${ }^{3}$ Spikes in the gamma log of the hole do not always have radioactive counterparts in the recovered core. Combined beta and gamma counts (measured in the cores rather than in the core hole) are recorded alongside the photographs to indicate location of high level radiation, glass seams, and position of the spikes in the gamma log whether or not the source of the radioactivity was recovered. Most of the readings were taken as the rock was removed from the core barrel. A few were made later, e.g., on small glass seams, and they should be interpreted with the recorded data in mind.

Narrow glass seams (Fig. 9) were first encountered at $164 \mathrm{ft}$ SHD (slant hole distance), which is $182 \mathrm{ft}$ from the shot point. They become increasingly abundant with approach to the chimney (at 181, 210, 214, 219, 223, 226, 229,

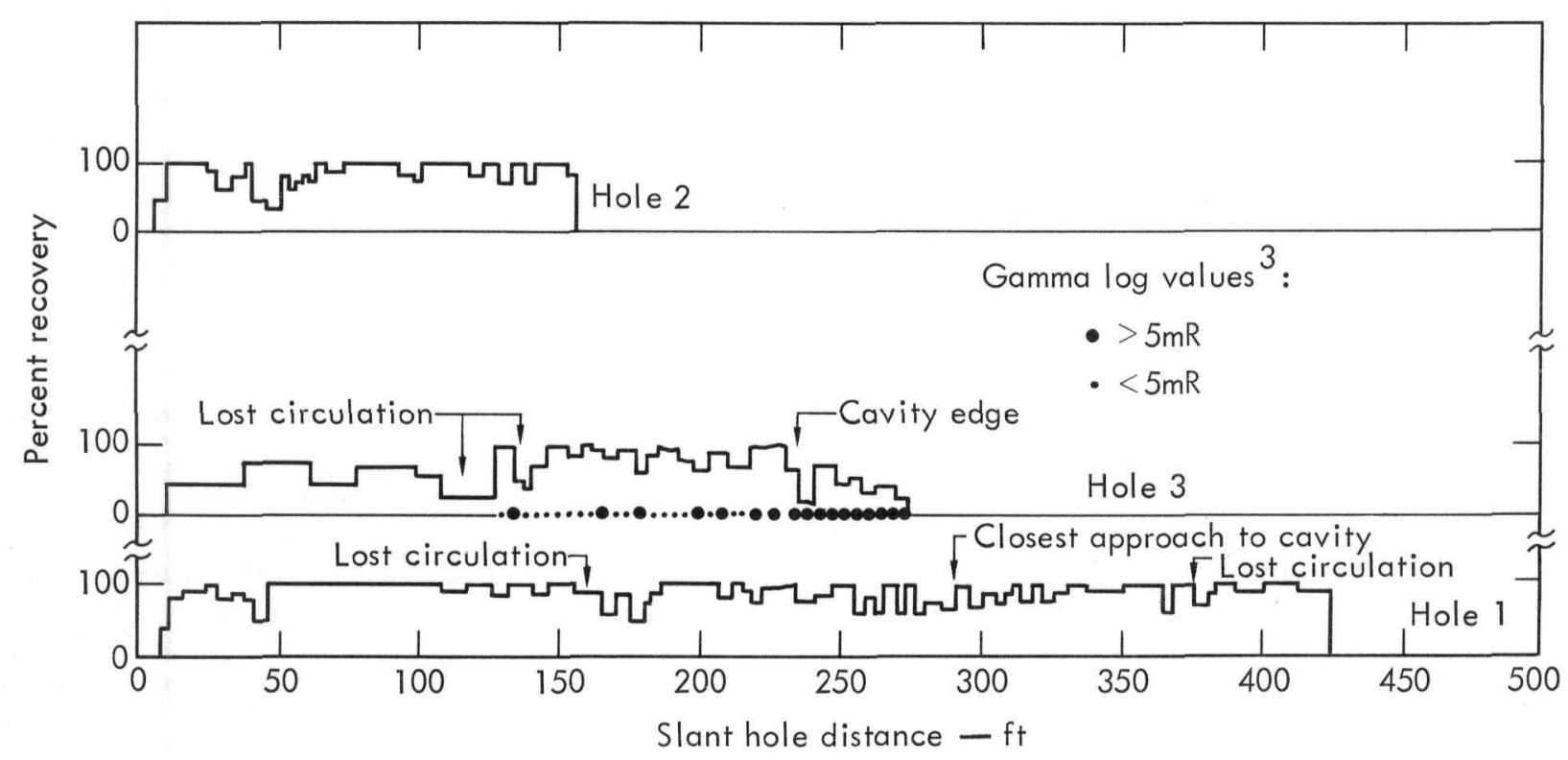

Fig. 8. Amount of core recovered in the three postshot exploratory holes. 


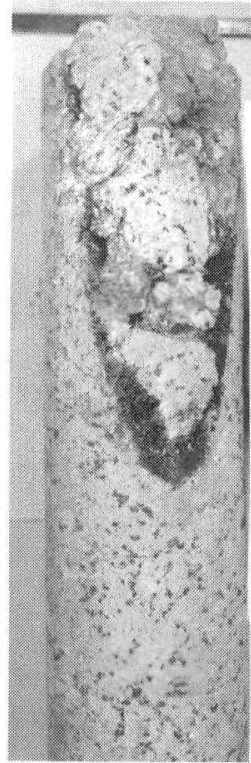

$232 \mathrm{ft}$

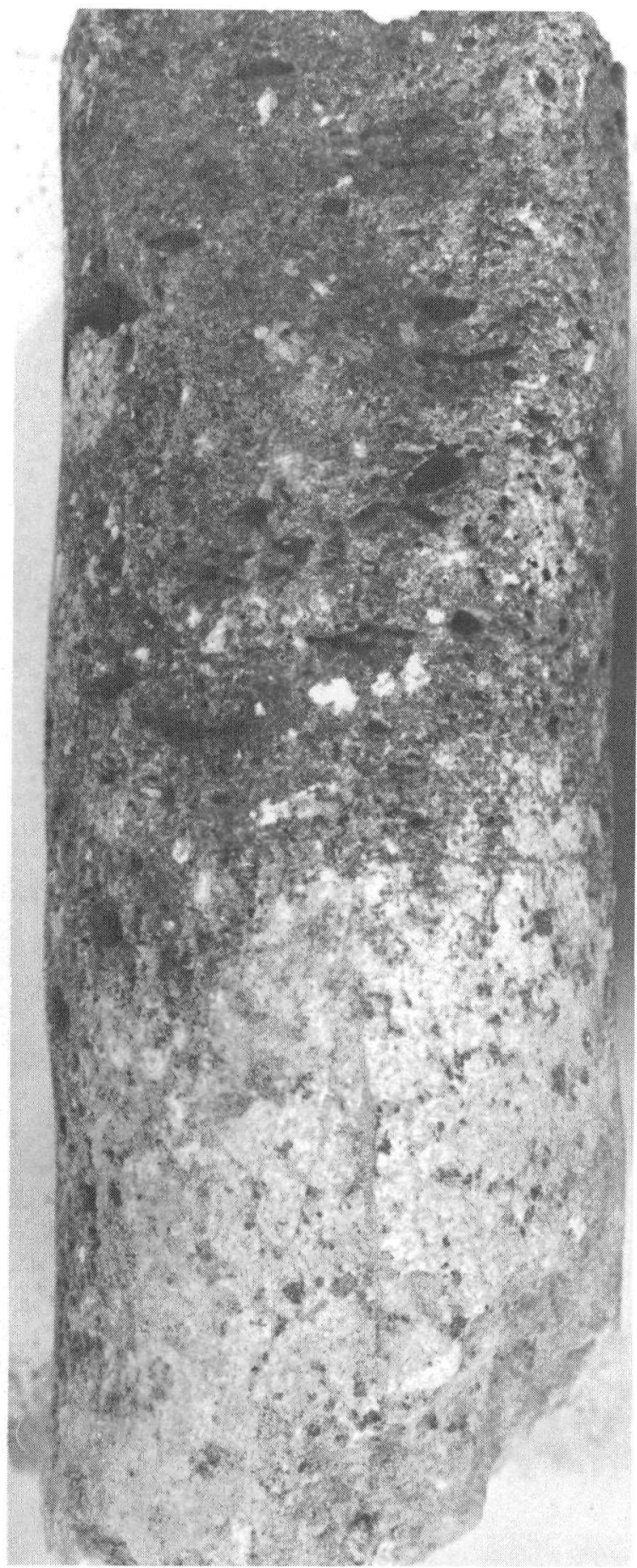

$226+t$

Fig. 9. Sections of core from hole 3, showing glass seams filling fractures (upper and lower left) and contact between granodiorite and cavity debris (right).

230, and $232 \mathrm{ft} \mathrm{SHD).} \mathrm{The} \mathrm{glass} \mathrm{fills}$ well-developed fractures that appear to be preexisting. At the nominal chimney/ country-rock intersection, black vesicular rock in a glassy matrix makes its appearance (Figs. 9,10). It can be quite coherent and the core fragments are commonly bounded by flat throughgoing surfaces 


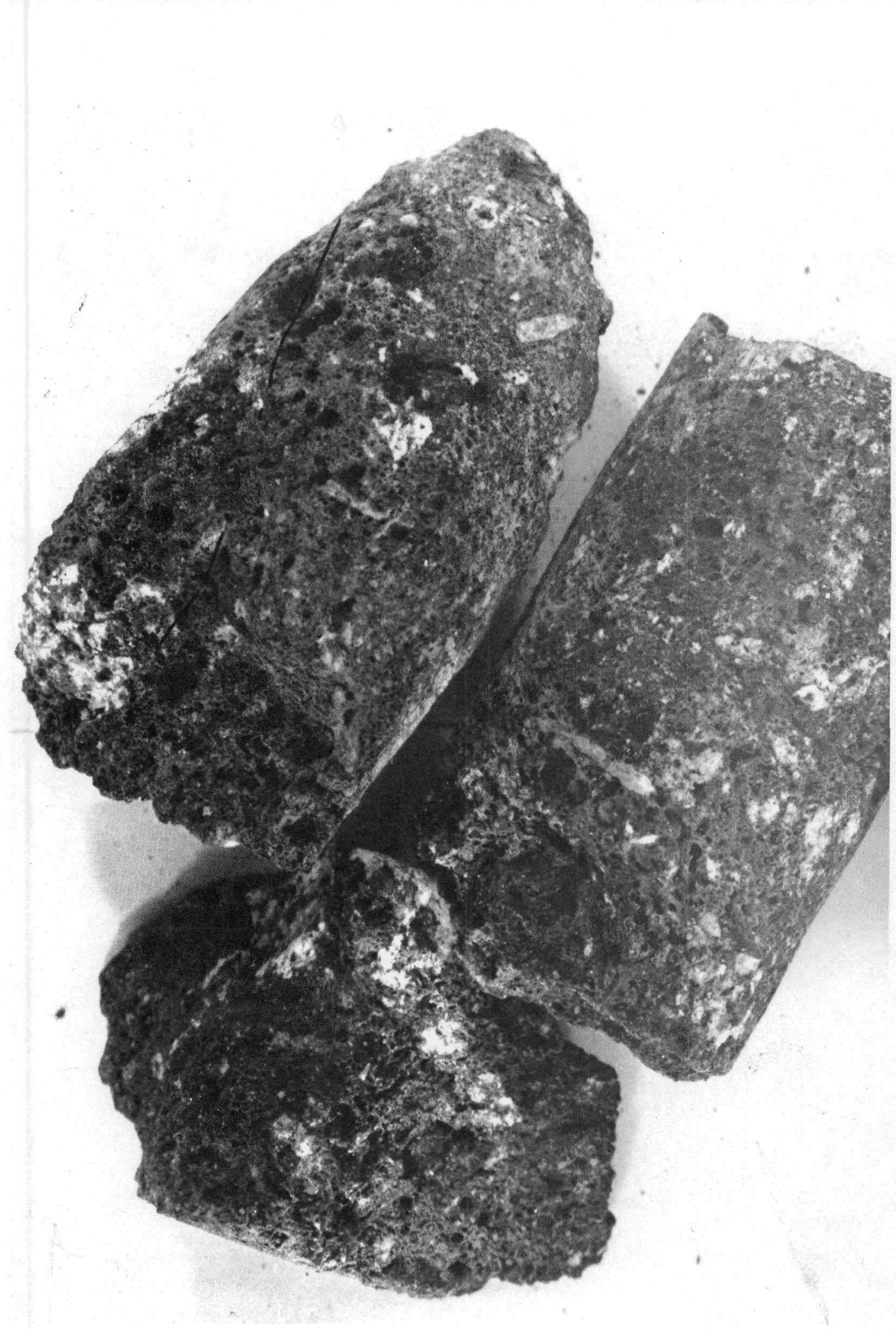

Fig. 10. Sections of core from hole 3 at depth of $233.5 \mathrm{ft}$, showing vesicular, glassy debris within cavity

(fractures) similar to those observed throughout all three cores (Fig. 11). The chimney rubble beyond this point consists of glassy vesicular debris to- gether with melted and highly fractured granite. It becomes generally more glassy along the core, but partially melted granitic spall occurs as well. 


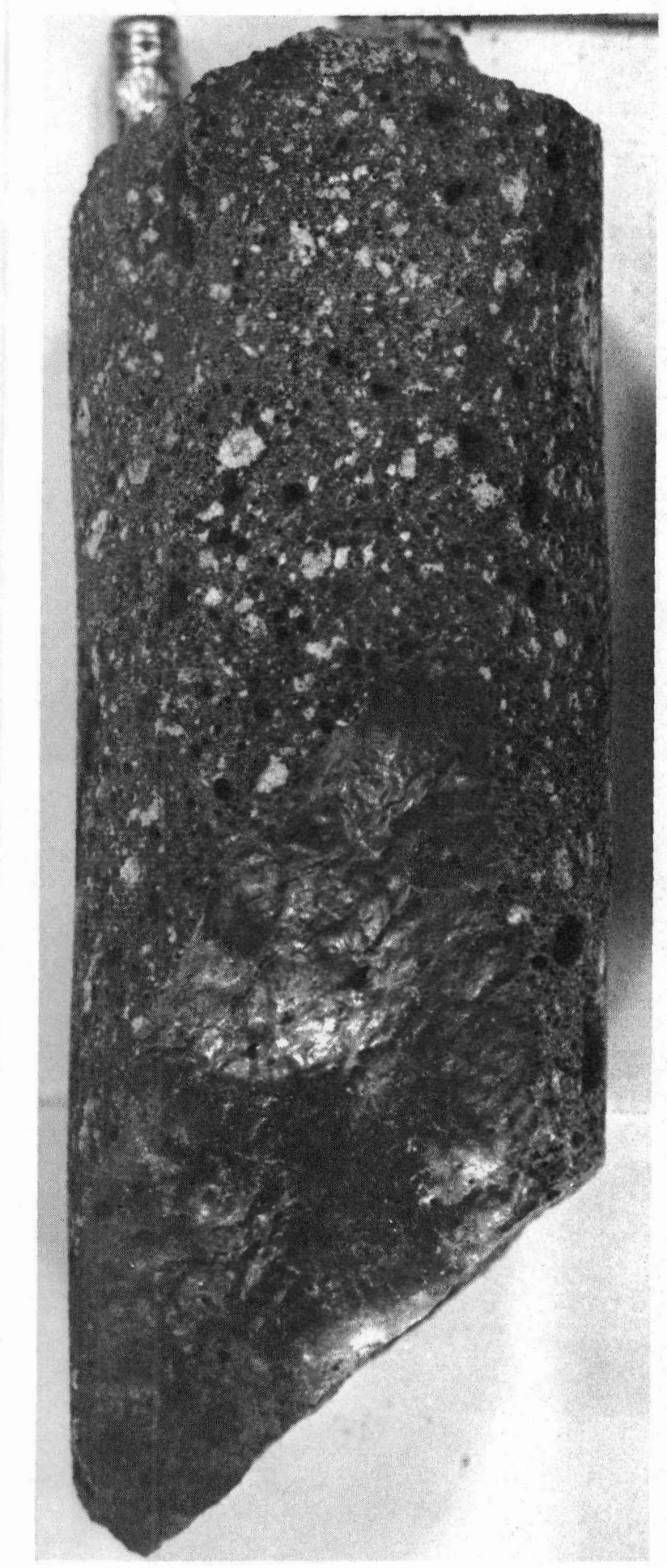

$258 \mathrm{ft}$

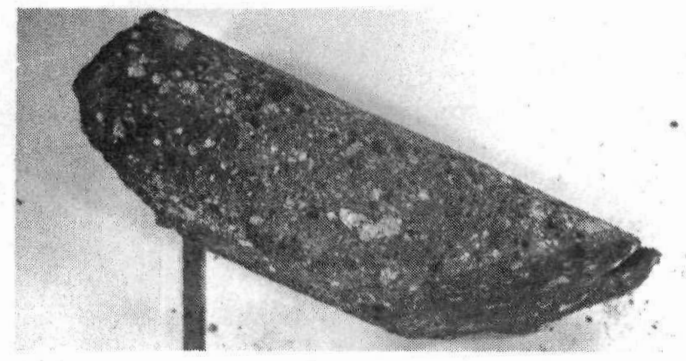

$260 \mathrm{ft}$

Fig. 11. Sections of core from hole 3. Core fracture (left) is coated with dull material that is presumably low-silicon glass. Sharp, planar fracturing is evident in vesicular, partially melted rock within cavity (right). 

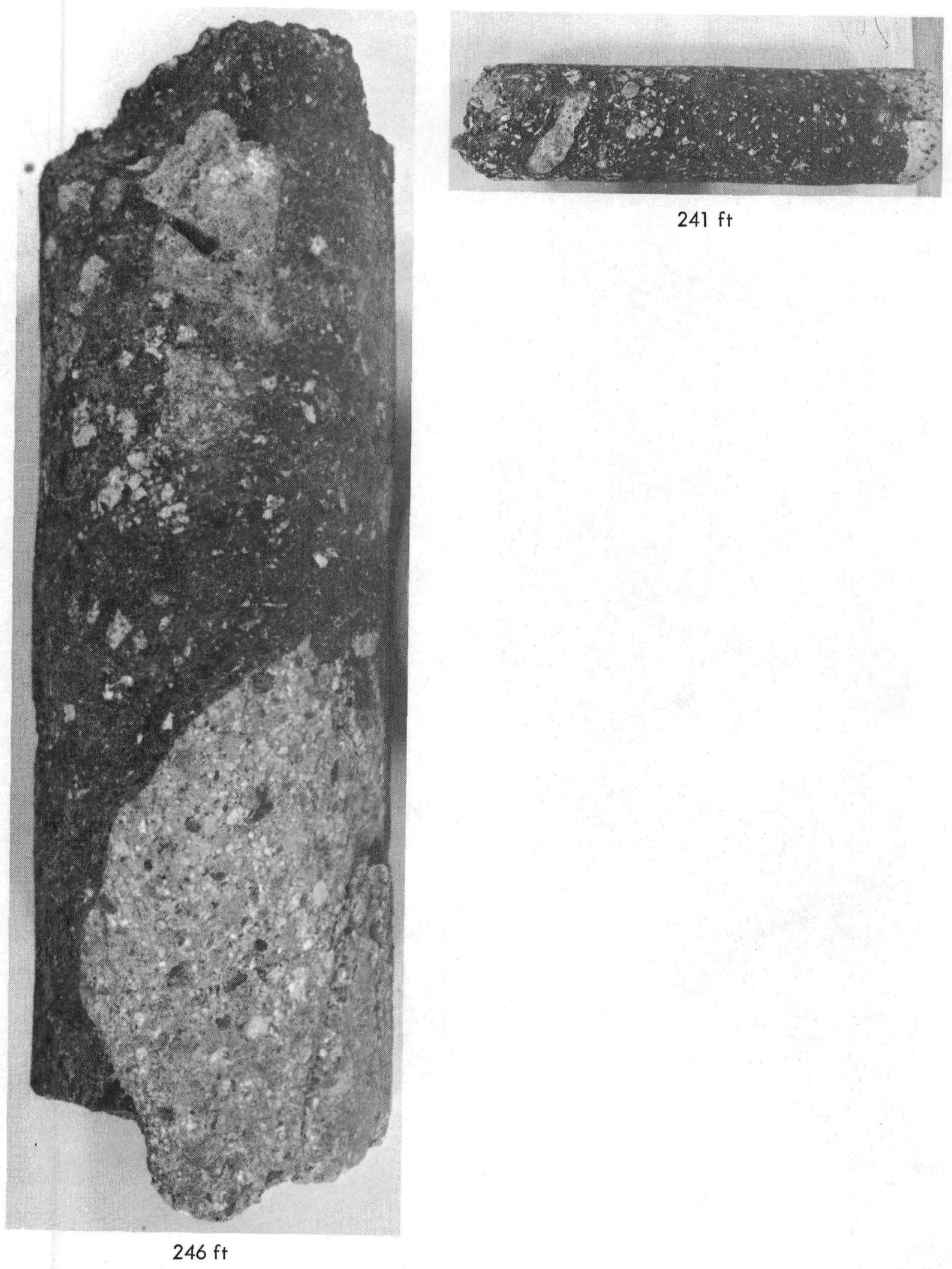

$241 \mathrm{ft}$

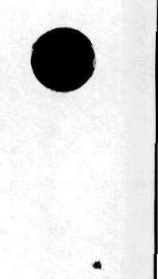


There are numerous examples of partially absorbed spall within the solidified vesicular glassy debris (Fig. 12).

\section{AMOUNT OF MACROSCOPIC FRACTURING IN THE CORES}

In cores 1 and 2 fractures are 1-6 in. apart. Almost certainly many of these open breaks are produced during the drilling and coring process, as stress relief cracks. The tacit assumption in analysis of core fracturing is that the measurable breaks comprise (1) shockinduced fractures, (2) "open" preexisting fractures and joints, (3) breaks produced during the coring process which are parallel to the planes of weakness (either shock-produced or preexistent), for example, healed fractures.

The amount of core in which fractures can be measured depends on the amount recovered $(89,86$, and $61 \%$ in holes $1,2,3$, respectively). This in turn depends on local vagaries such as intersection with preexisting fault and shear zones as well as drilling and recovery techniques. For example, sampling and recovery was poor within a 28 -ft-wide shear zone encountered in hole 2. For the purposes of study of fracture orientation or frequency, core 3 is considered almost a total loss because of its poor condition. This is believed to be a consequence of intersection of a wide shear zone at a considerable distance from the shot point as well as recovery techniques inferior to those used for the other two cores. ${ }^{3}$ Measurement of fracture orientation in such rubble is difficult and only a few fractures out of the total present are represented in the compilations that follow. Thus the actual number of fractures re- corded within any particular interval in a core is often meaningless. A comparatively low number per foot of core can indicate either that fracturing has been minimal or that fracturing of either preor post-shot origin has been so extensive as to affect the amount of core recovered and/or the number of fractures whose orientation relative to the core axis can be determined.

\section{ORIENTATION OF FRACTURE PLANES IN THE CORES}

Detailed postshot examination of failure in the CR and DL drifts, ${ }^{29} 256$ and $287 \mathrm{~m}$ respectively from the shot point, indicates that partial collapse of these drifts was controlled by movement and dilation of preexisting fractures and faults. There is good evidence that the shape of the chimney, at least in the section which was subject to postshot examination, was also influenced by the presence of one or more pervasive fracture sets. One of the problems to be addressed is to what extent the fracturing throughout the shocked body of granite is similarly influenced.

Lacking oriented core, i.e., core whose original orientation with respect to the shot point is uniquely determined, the orientation of fractures cannot be unambiguously determined. Accordingly, fracture orientation has not been attempted in any previous core study. ${ }^{34,35}$ However, some information can be gained by recording the angle $\phi$ between the core axis and the fracture planes along the whole length of a core. For example, it is possible to determine whether or not the data are consistent with the following possibilities and hypotheses: 
1. Randomness of $\phi$ in the whole core as well as within particular core intervals. A random distribution of $\phi$ which is nonGaussian" is shown in Fig. 13 for 1500 hypothetical core fractures. A random distribution of $\phi$ does not necessarily equate with a random orientation of fractures with respect to the shot point. Fractures of the shear type taken as a group in the core might produce a nearly random distribution of $\phi$ angles in cores whose axes do not coincide or nearly coincide with a radial line from shot point. A nonrandom distribution of $\phi$, on the other hand, is definitive whether measured over the whole core or within a given core interval. Assuming adequate sampling it can be correlated with nonrandom fracture orientation.

2. Coincidence of core fractures with preexisting sets. Because preexisting sets make a constant angle with any core axis or radial line to shot point, foreknowledge of their attitude permits recognition of their control over the observed postshot fracture pattern if it is strong. If instead new fractures are geometrically related to the main direction of propagation of the shock wave, e.g., as shear fractures, a weak structural control on

\footnotetext{
A random (isotropic) distribution of this type of measurement is sinusoidal. Within any class interval defined by $\theta_{1}$ and $\theta_{2}$. the percentage of points is given by

$P=100 \int_{\theta_{1}}^{\theta_{2}} \sin \theta d \theta=100\left(\cos \theta_{1}-\right.$

$\cos \theta_{2}$ ) for angles between lines ${ }^{36}$

$=100 \int_{\theta_{1}}^{\theta_{2}} \sin \left(90^{\circ}-\theta\right) \mathrm{d} \theta=100\left(\sin \theta_{2}-\right.$
}

$\sin \theta_{1}$ ) for minimum angles between a line and planes.

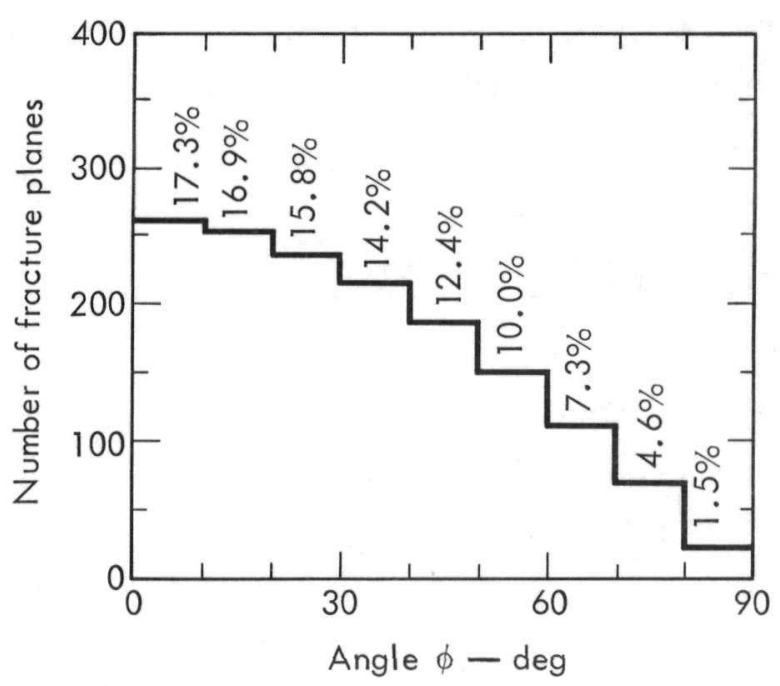

Fig. 13. Isotropic (random) distribution of $\phi$-angles between a core axis and 1500 fracture planes calculated in $10^{\circ}$ increments.

the orientation of core fractures could not be recognized.

3. Coincidence of the core fractures with sets either tangentially or radially oriented with respect to shot point. The angle such fractures make with the core is variable from place to place along the length of the core. It is, however, uniquely defined at any particular position. Thus, given the core bearing and the position within the core, the angle $\phi$ for tangential and radial fractures at that point can be computed and compared with the observed angle(s). Figure 14 shows the variation in position that hypothetical tangential $(T)$ and radial $(R)$ fractures have along the lengths of the three cores.

4. Coincidence of core fractures with planes of potential shear failure. Most of the fractures within about $100 \mathrm{~m}$ of the shot point would be expected to arise during failure in compression, e.g., as shear fractures. If the mean peak pressure is sufficiently high, their orientation is not as likely to be influenced by 


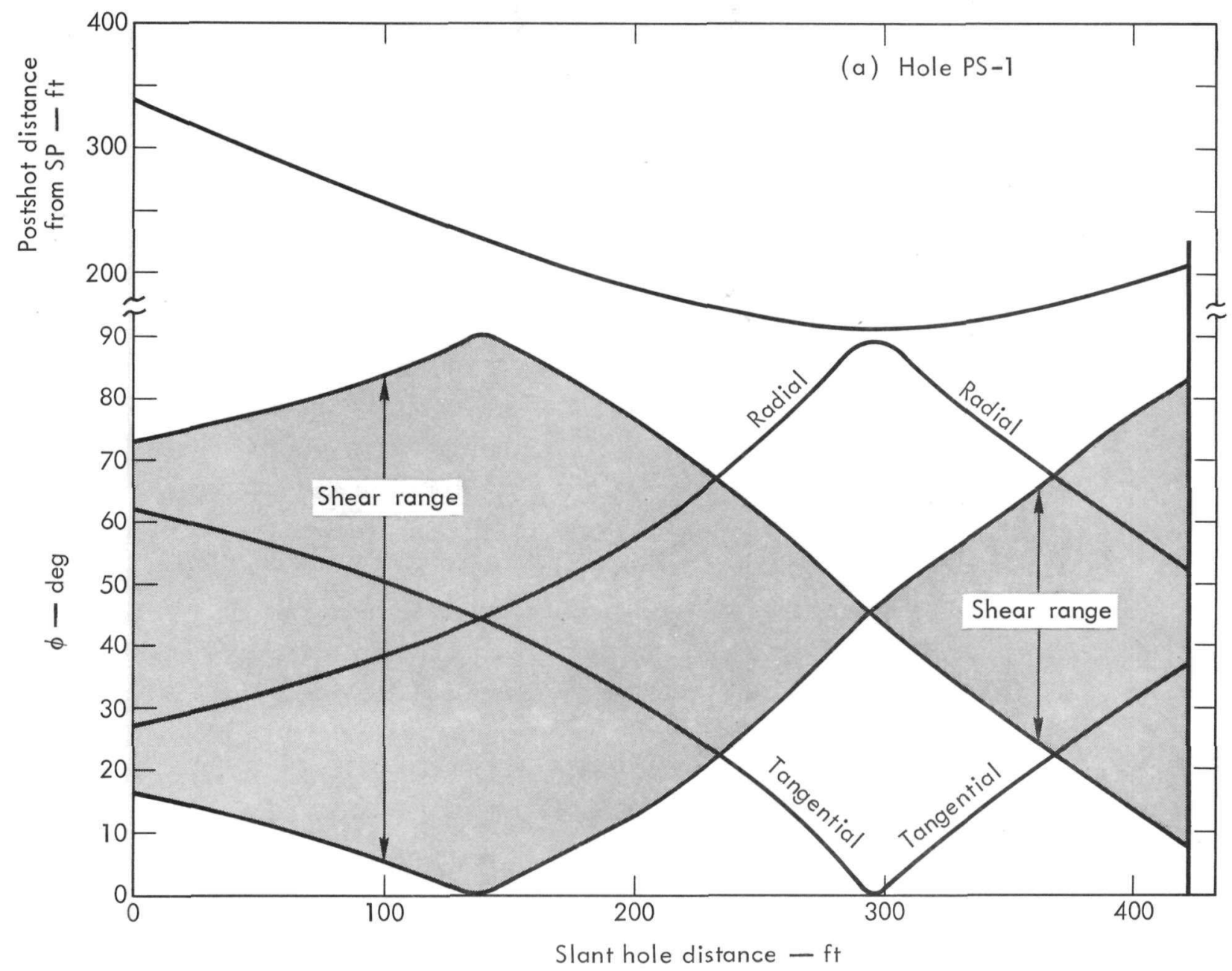

Fig. 14. Variation in $\phi$ for radial, tangential, and shear $\left(45^{\circ}\right.$ to $\left.\sigma_{1}\right)$ fractures along the three core lengths from holes PS-1, -2, and -3. Radial and tangential fractures make unique angles to core axes; a wide range of $\phi$ is consistent with shear failure.

preexisting planar weaknesses as by the position of the principal stresses. ${ }^{37}$ For isotropic material in which $\sigma_{2}=\sigma_{3}$, the locus of shear fractures is a cone whose axis is in the direction of propagation of the main shock wave and whose semiapex is $30-45^{\circ}$ depending on the physical properties of the material. At any point in a core with random bearing with respect to the shot point, potential fractures tangent to the cone occur within definable angular limits. "Since the angular range is generally large (Fig. 14), a test for consistency of a shear interpretation at any point in a core is possible but not useful. Exceptions occur where a core axis is either parallel or perpendicular to a radial line from the shot point. In these two instances shear fractures make angles of about $30-45^{\circ}$ and $45-60^{\circ}$ respectively with the core axis. In the more general case, a second spherical coordinate in addition to the $\phi$ angle is needed to

"Limits on $\phi$ are determined from projections or drawings in the plane defined by the core axis and the shot point. In the present instance, this coincides with the plane of Fig. 7 for all cores. 


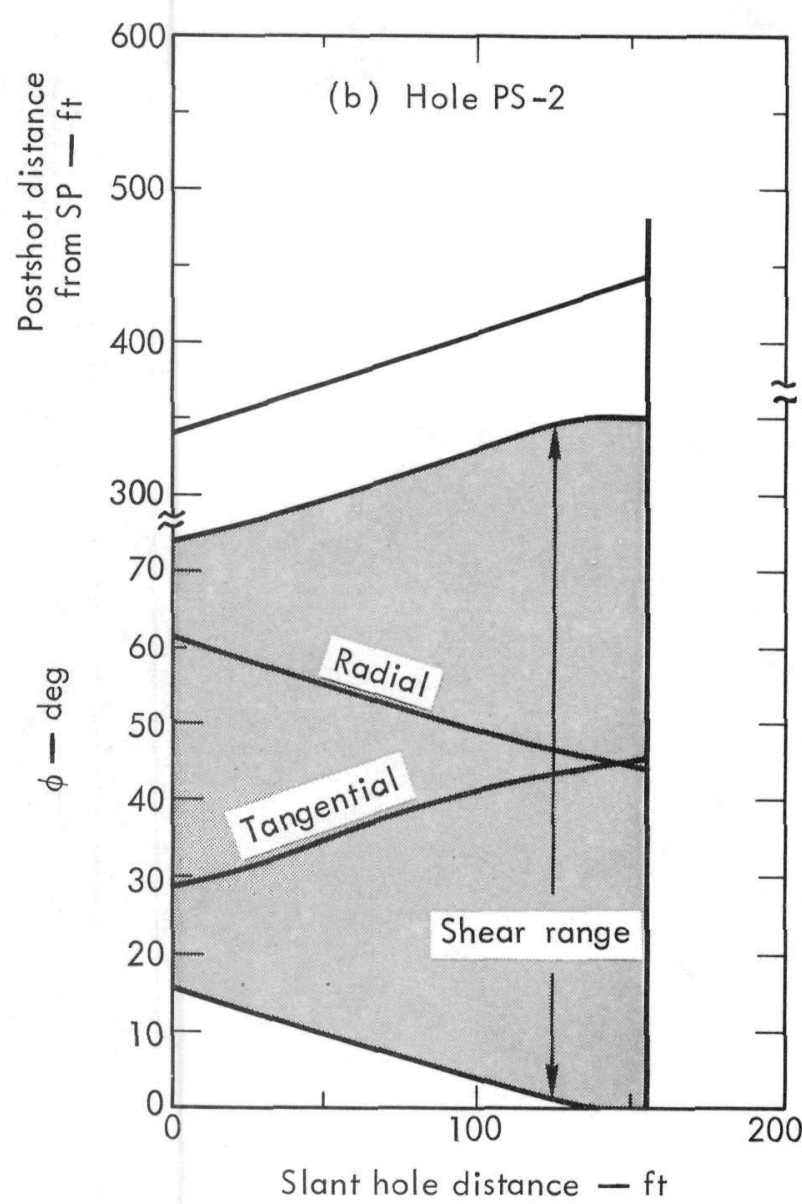

Fig. 14. (Continued)

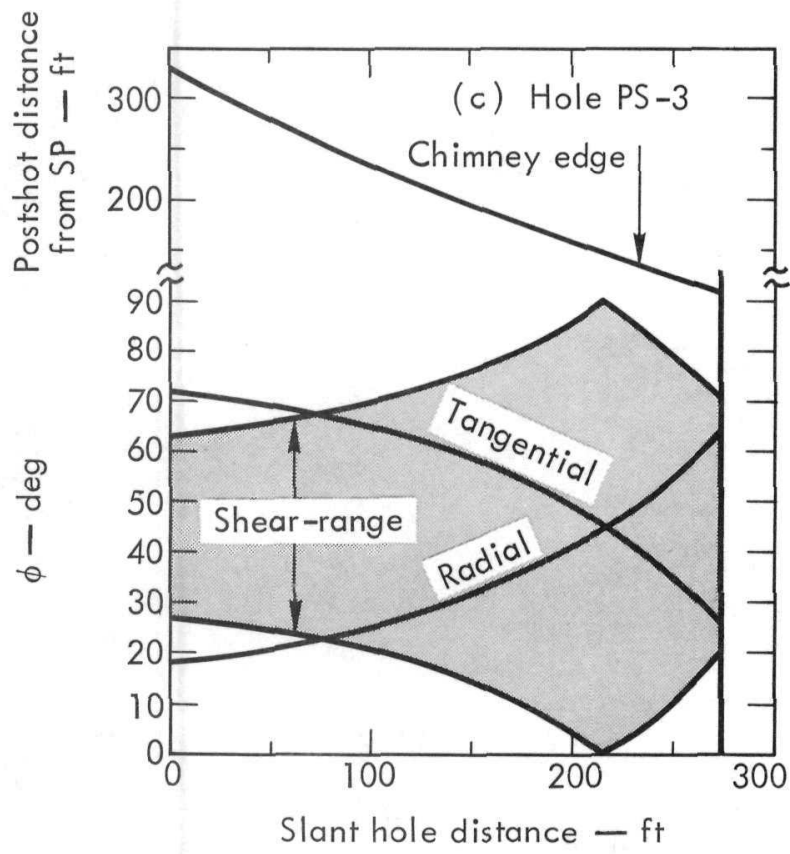

Fig. 14. (Continued) determine whether the fracture fits the chosen shear criteria.

In summary then, the data available, namely measurements of the angle $\phi$, can only test whether or not the observations are consistent with the various possibilities. Inconsistency constitutes good reason for disregarding the hypothetical relation. Consistency, on the other hand, does not verify the model.

Some preshot joints and fractures are sites of alteration and mineralization and are readily recognized as such. Core fractures of this sort thus provide a check on the orientation of preshot fractures with respect to the core axis as deduced from field studies shown in Fig. 15. The exact shape of the distribution to be expected is contingent on a knowledge of the relative degree of development of each of the sets recognized in the stock

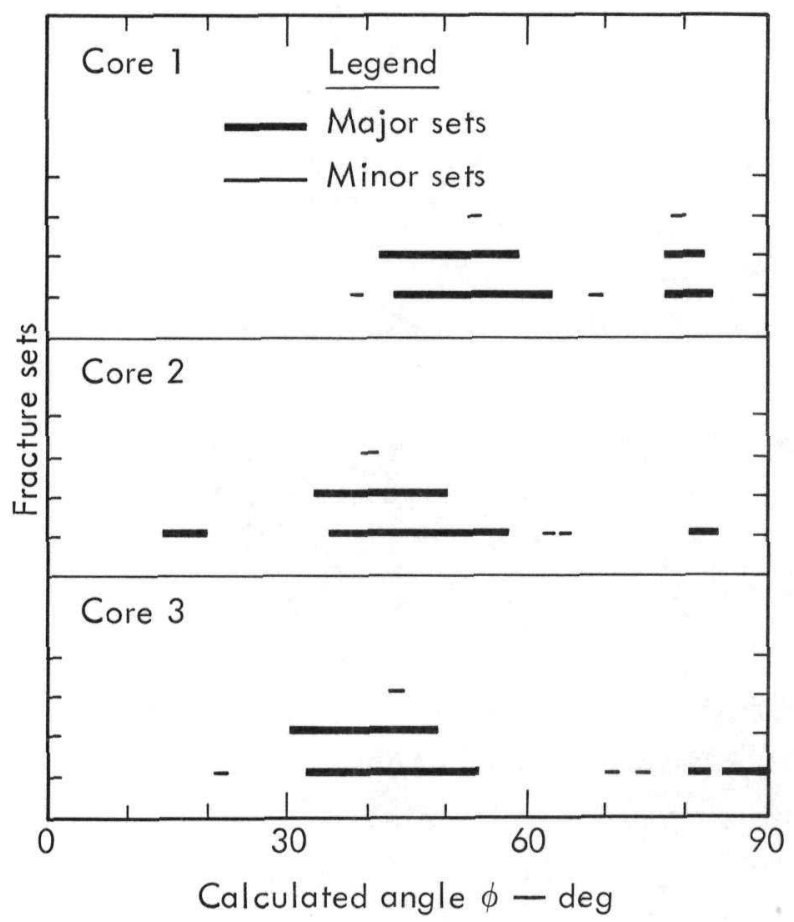

Fig. 15. Calculated angle $(\phi)$ between core axes and various preexisting fracture and joint sets in Climax stock. 

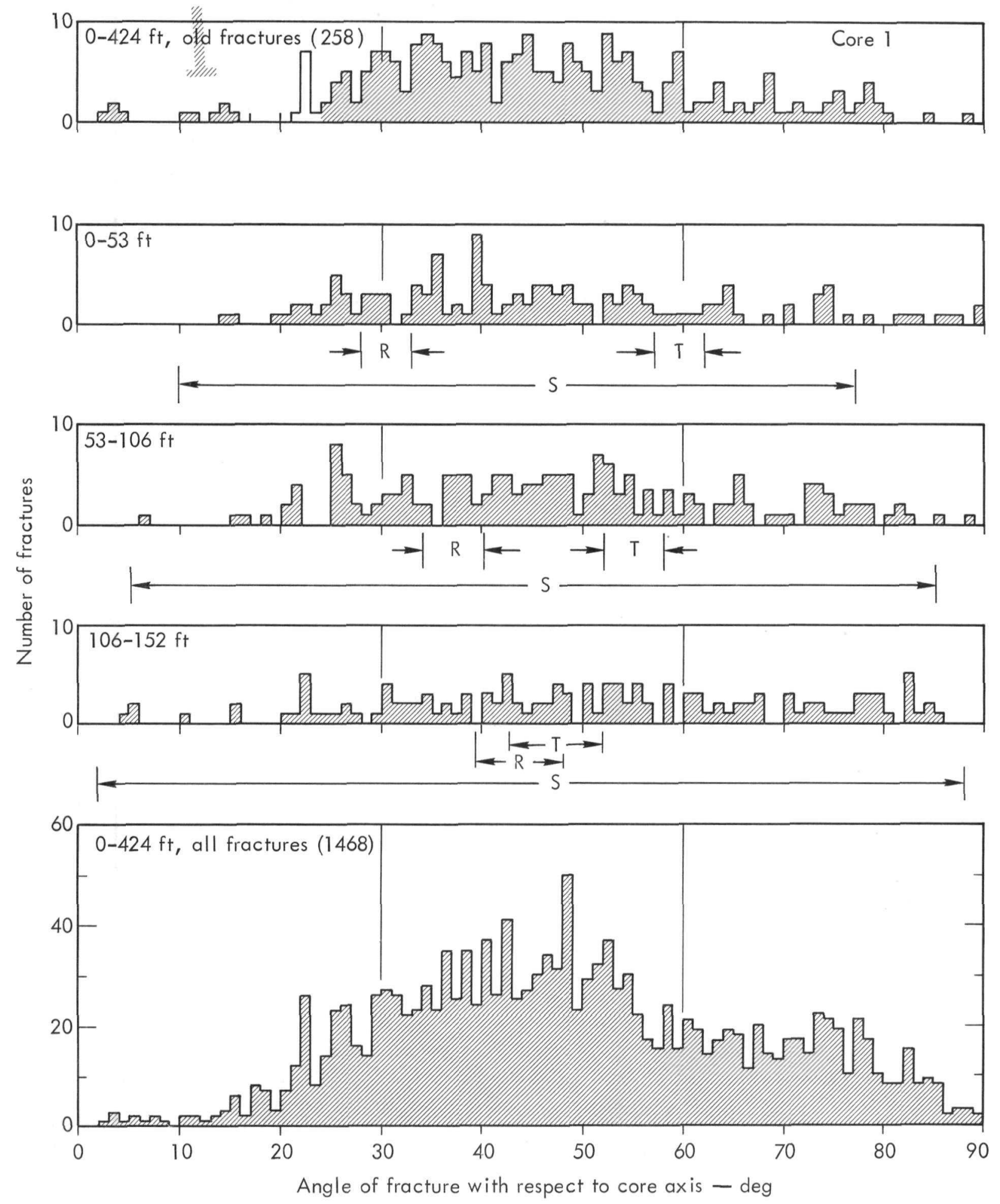

Fig. 16. Measured $\phi$ for 1458 macroscopic core fractures in core 1.

at any point along the core length (Table 5). the comparable data from measurement As this information is lacking, Fig. 15 of altered and mineralized fractures in is only a qualitative guide. The top the cores. Data from cores 2 and 3 are histogram of Figs. 16, 17, and 18 shows probably too sparse for comparison with

$-25-$ 

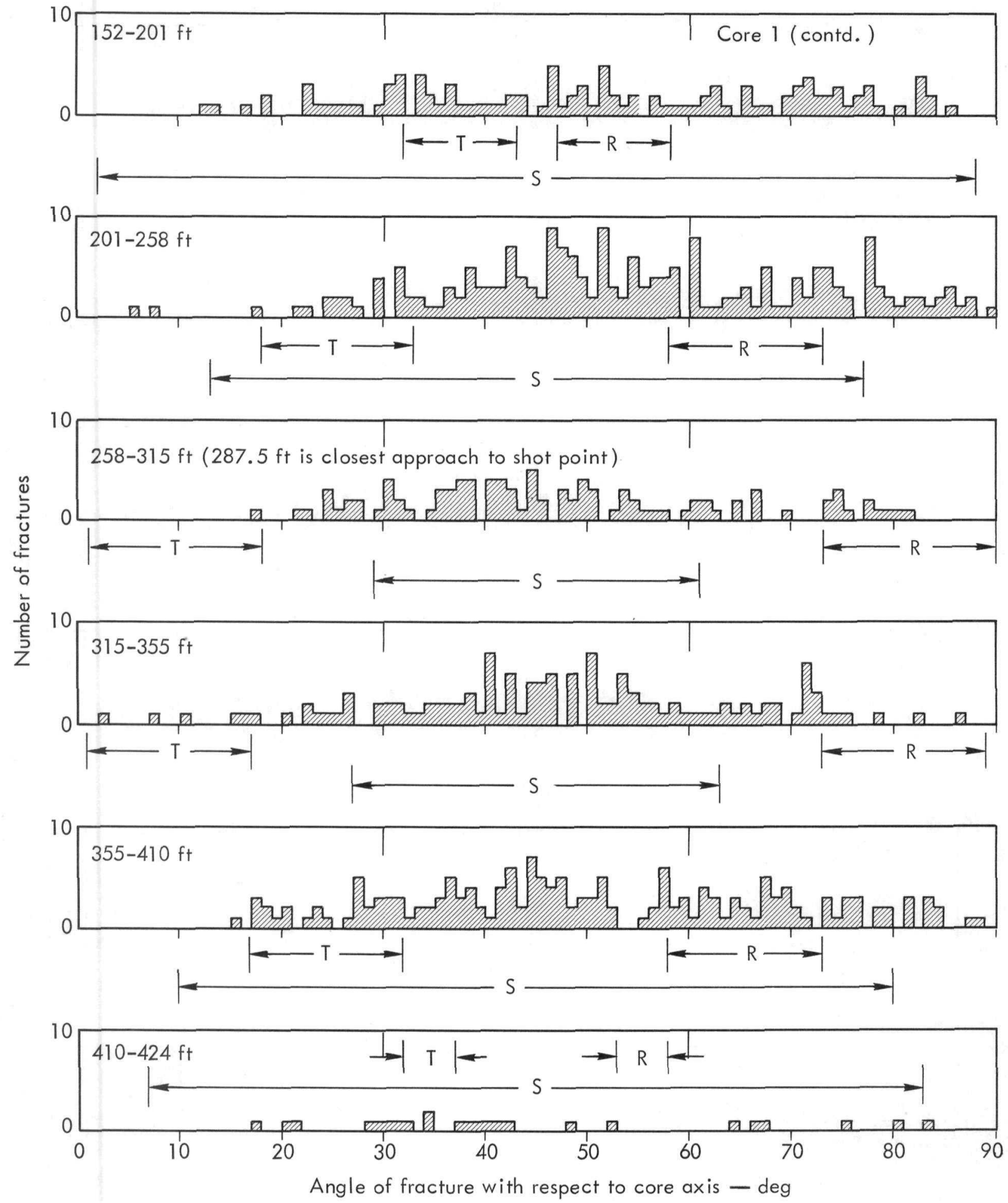

Fig. 16. (Continued)

the estimated distribution shown in Fig. 15; Fractures represented in the 80-90 however, data from core 1 show general agreement in that most preshot fractures make angles of $30-53^{\circ}$ with the core axis. range (Fig. 15) are either unmineralized or poorly developed in the area cut by the core. Comparison of these data with 

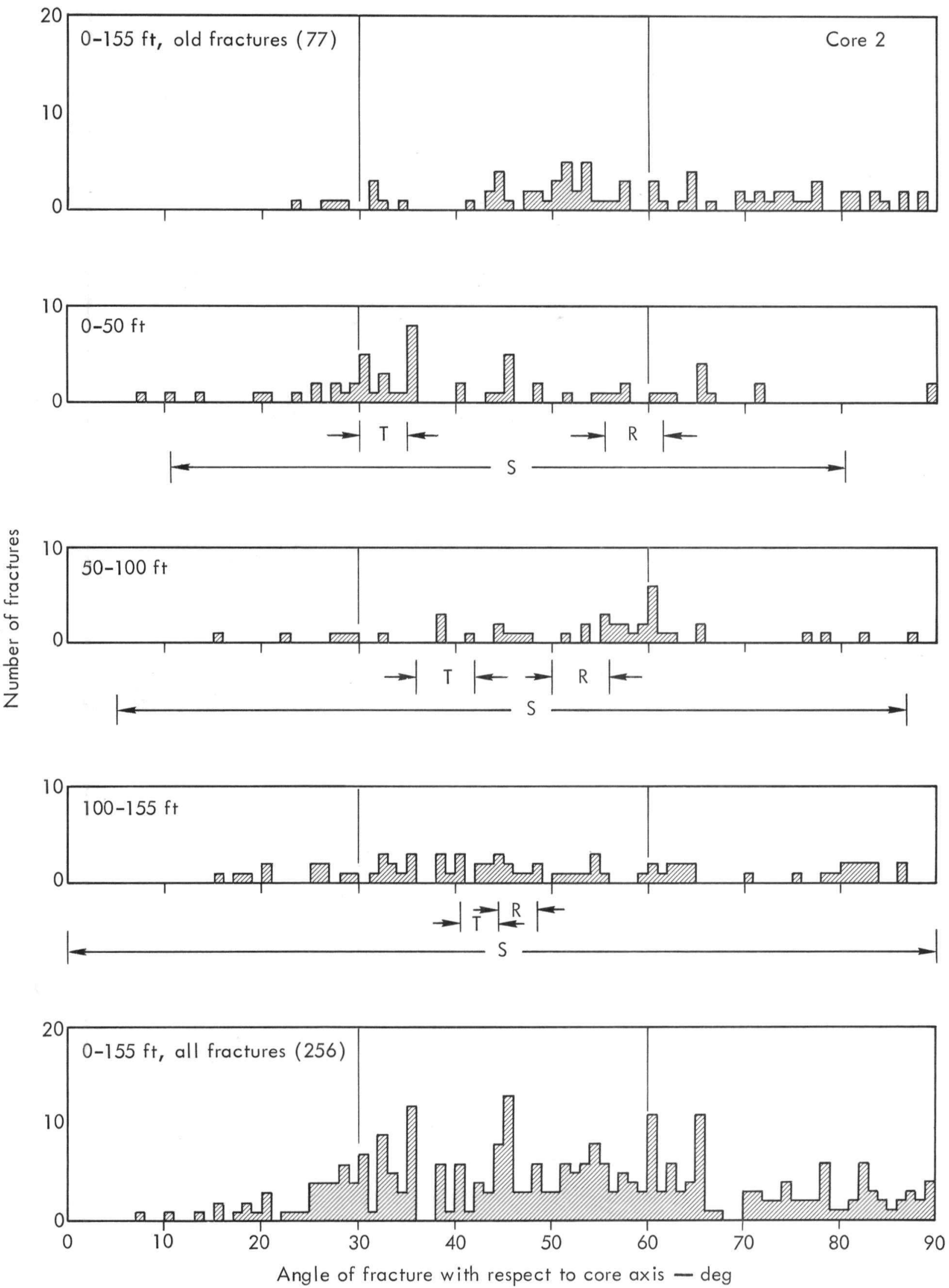

Fig. 17. Measured $\phi$ for 256 macroscopic core fractures in core 2. 

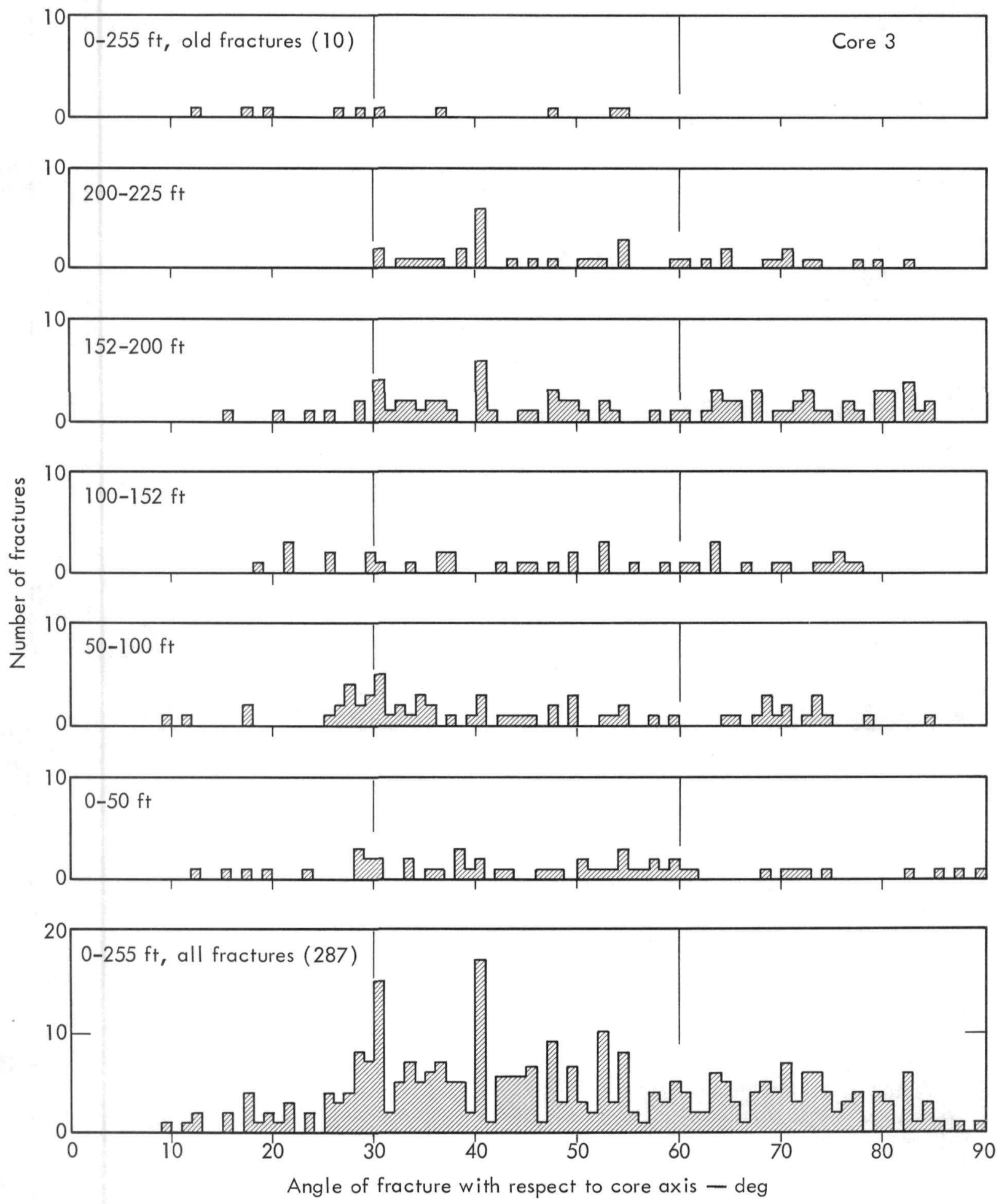

Fig. 18. Measured $\phi$ for 287 macroscopic core fractures in core 3 .

those of Fig. 13 further emphasizes the nonrandomness of preexisting fractures.

Figures 16, 17, and 18 show the angular relation of observed fractures to the core axes in approximately 50 -ft sections of the cores. Fractures that can be recognized as preexisting are not included. Each histogram contains the range of 
angles that tangential $(T)$, radial $(R)$, and shear (S) fractures would make with the core axis within that 50-ft interval.

The final histogram shows the distribution of $\phi$ for all fractures measured in each of the three cores. Such an accumulative plot is only meaningful if the orientation of observed fractures is largely controlled by preexisting discontinuities. Presumably such a plot would be nearly random if the orientation of observed fractures were symmetrically related to a point source.

\section{IMPLICATIONS OF OBSERVED ORIENTATIONS OF FRACTURE PLANES}

The observed macroscopic fractures in postshot cores are not randomly oriented. As a whole their departure from randomness is in directions consistent with their interpretation as loci of preshot planes of weakness - fractures and/or joints. In general there is no local correlation between measured $\phi$ and calculated $\phi$ for tangential and radial fractures. The consistency test for shear fracturing is poor over most of the core lengths; however, where it can be used, the $\phi$ angles are inconsistent with shear fracturing.

In only one core (core 2) is there any suggestion that fractures might be symmetrically related to a point. Specifically, in the first $50 \mathrm{ft}$ along the core, fractures are possibly tangential; and in the slant hole interval from 69 to $100 \mathrm{ft}$ (117-123 m from the shot point) they are consistent with the positions of radial fractures. It can be readily shown that the first group of fractures in the 0-50 ft interval are also geometrically consistent with radial fracturing associated with a reflected shock wave from the adjacent interface formed by the 10-ft-diam access tunnel.

At this distance (117-123 $\mathrm{m}$ ) from the shot point, radial fracturing is consistent with failure in compression at low stress levels. The SOC calculation ${ }^{13}$ predicts onset of "release fractures" approximately $170 \mathrm{~m}$ from the shot point. Thus the observations are consistent with the models; however, the relatively few fractures measured in the interval make the interpretations tenuous.

\section{Summary and Conclusions}

The foregoing constitutes a summary of a large body of information dealing with the Piledriver event in granodiorite. From measured data reported by cooperating agencies, the peak radial stress seen by surviving rock at the cavity edge is $250-270 \mathrm{~kb}$. Rock presently at a distance of $1148 \mathrm{ft}(350 \mathrm{~m})$ from the shot point saw less than $1 \mathrm{~kb}$ radial pressure. The radius of the vaporized and melted fraction is $51.2 \mathrm{ft}(15.6 \mathrm{~m})$ as calculated from Butkovich's estimates of the weight of rock per kiloton involved in the various vaporization and melting processes. From the final cavity radius of $131.5 \mathrm{ft}$ $(40.1 \mathrm{~m})$ a maximum displacement or "heave" of $80.3 \mathrm{ft}(24.5 \mathrm{~m})$ can be computed for rock at the present cavity edge. At $1000 \mathrm{ft}(305 \mathrm{~m})$ from the shot point the radial displacement was less than $1 \mathrm{ft}$. Clearly, local conditions can alter these estimates, especially in the vicinity of 
the tunnel void that existed as a discontinuity at shot time.

Nine predictions of the radius of the cavity have been compared. The equations of Higgins and Butkovich, Chapin (based on adiabatic expansion of cavity gases to twice overburden pressure), Boardman, Heard and Ackerman, and Michaud result in predictions that are within 0-4.5 ft of the value determined from field measurements. The remaining four estimates are within 12.5 to $23.5 \mathrm{ft}$ of the accepted value and represent a maximum error of $18 \%$. Four of the five predictions made by LRL scientists are in error by less than $5 \%$. Thus cavity radii can be predicted with some confidence, given appropriate physical parameters of the surrounding rock.

The volume occupied by the chimney is not so predictable. The Piledriver chimney is not shaped like a cylinder with semihemispherical ends, as one might expect. Sterrett was the first to note that at least the SW wall is canted $13^{\circ}$ from the vertical due to collapse and shearing along preexisting fractures and/or joint systems. The survey of preshot fracture and joint systems measured within the stock (Table 5) shows that these local shear zones are part of the regional pattern. As there are at least four major fracture and/or joint sets recognized, it is likely that they have similarly influenced the configuration in portions of the chimney as yet unexplored. . Furthermore, it is possible that the shape of the Hardhat chimney $1 / 4$ mile away within the same granodiorite is similarly influenced by preexisting fractures and shear zones. Hardhat chimney explora- tion was not extensive enough to test the hypothesis. Assuming that the preexisting discontinuities in the stock govern the attitude of chimney walls, more than onehalf of the Piledriver chimney would be expected to be cup-shaped (walls slanting outward about $13^{\circ}$ from the vertical), and the remainder to have walls departing only slightly from the vertical as was found in the portion of the Hardhat chimney explored to date.

A thorough knowledge of chimney volume and hence chimney shape is of great importance in most economic plans designed to utilize the broken rock-e.g., recovery of oil from oil shale and ore winning. 38 For a given cavity radius, $r_{c}$, the volume of a chimney can vary by several factors. For example, the volume of the French chimney model, an egg-shaped unit approaching the shape of a prolate spheroid, is $19.3 \mathrm{r}_{\mathrm{C}}^{3}$ as compared to $12.6 \mathrm{r}_{\mathrm{c}}^{3}$ for an axially symmetric, straight-walled chimney patterned after the one explored planar section through the Hardhat rubble shown in Fig. 7 (b).

Three drill cores (U-15.01 PS-1, -2, and -3 ) recovered from rock both outside and inside the chimney have been visually examined before being subjected to extensive sampling for laboratory tests. The attitudes of several thousand macroscopic fractures were determined with respect to the core axes and distance from the shot point. All three cores were photographed in their entirety. The positions of injected glass seams, radioactivity, and gross recognizable shear zones were noted.

Core fractures cannot be uniquely oriented with respect to the shot point; however, they are demonstrably nonrandomly 
oriented. Their positions are consistent with failure along preexisting regional joints, fractures, and shear zones. With one possible exception, in no core interval are their positions consistent with fracturing parallel or perpendicular to the direction radially outward from the shot point. With the core information available, the test for shear failure at any point or core interval is not sufficiently precise to determine whether or not the orientation of the observed fractures are also consistent with an origin through shear.

The amount of fracturing observed in a recovered core cannot be used as a reliable guide to the amount of shockinduced fracturing in the rock the core came from, because in general highly fractured rock is not recovered. The amount of core recovered is in addition influenced by preexisting shear zones, by slightly different drilling techniques used for the several cores, and by temporary drilling problems within individual drill holes. Nonetheless, taking all uncertainties into account, there is evidence that at the same radial distances from the shot point the amount of fracturing is variable. Specifically in core 1 there is more fracturing near the chimney wall than beneath the cavity within core intervals equidistance from the shot point. The phenomenon is most likely related to local, well-developed, preexistent fracture systems in the granitic stock. Comparable inhomogeneities might be expected to be the rule rather than the exception in most underground tests.

\section{Acknowledgments}

I am grateful to many people at LRL for profitable discussions and comments on the report. They are H. Heard, C. Chapin, T. Butkovich, C. Sisemore, D. Rabb, L. Ramspott, A. Lewis, and
G. Higgins. I am particularly grateful to A. Horn for his thorough description of core 3 as it was pulled from the core barrels and for subsequently measuring the macroscopic fractures. 


\section{Appendix 1 \\ Summary of Projects Included in Piledriver Event}

Table 1.1 gives basic information on the projects conducted as part of the Piledriver event.

Table 1.1 Summary of Piledriver projects. ${ }^{14}$

\begin{tabular}{|c|c|c|c|c|}
\hline $\begin{array}{l}\text { Project } \\
\text { No. }\end{array}$ & $\begin{array}{l}\text { Project } \\
\text { title }\end{array}$ & Agency & $\begin{array}{l}\text { Project } \\
\text { officers }\end{array}$ & Report No. \\
\hline 1.1 & Surface Motion & $\begin{array}{l}\text { Stanford Research } \\
\text { Institute (SRI) }\end{array}$ & $\begin{array}{l}\text { W. M. Wells, } \\
\text { F. M. Sauer }\end{array}$ & POR 4000 \\
\hline $1.2 \mathrm{a}$ & $\begin{array}{l}\text { Free-Field } \\
\text { Motion }\end{array}$ & Sandia Corp. & $\begin{array}{l}\text { D. G. Palmer, } \\
\text { H. R. Holmes, } \\
\text { W. R. Perret }\end{array}$ & POR 4001 \\
\hline $1.3 \mathrm{a}$ & Close-In Stress & $\begin{array}{l}\text { Illinois Institute } \\
\text { of Technology } \\
\text { Research Inst. } \\
\text { (IITRI) }\end{array}$ & P. Lieberman & POR 4002 \\
\hline $1.3 b$ & Close-In Stress & SRI & C. T. Vincent & POR 4003 \\
\hline 1.4 & $\begin{array}{l}\text { Strong Motion } \\
\text { Seismic }\end{array}$ & USCGS & T. H. Pierce & $\begin{array}{l}\text { Cancelled by ARPA } \\
8 / 31 / 65\end{array}$ \\
\hline $1.5 \mathrm{a}$ & $\begin{array}{l}\text { In Situ Stress } \\
\text { in Granite }\end{array}$ & $\begin{array}{l}\text { US Bureau of } \\
\text { Mines }\end{array}$ & L. Obert & - \\
\hline $1.5 \mathrm{~b}$ & $\begin{array}{l}\text { In Situ Stress } \\
\text { in Granite }\end{array}$ & $\begin{array}{l}\text { Lucius Pitkin, } \\
\text { Inc. }\end{array}$ & F. H. Wright & POR 4005 \\
\hline 1.6 & $\begin{array}{l}\text { Seismic Studies } \\
\text { in Granite }\end{array}$ & USGS & J. H. Scott & $\begin{array}{l}\text { USGS Technical } \\
\text { Letter Piledriver }-1\end{array}$ \\
\hline 3.1 & $\begin{array}{l}\text { Tunnel Liner } \\
\text { Response }\end{array}$ & $\begin{array}{l}\text { Omaha Dist., CE } \\
\text { (U.S. Army Corps } \\
\text { of Engineers) }\end{array}$ & $\begin{array}{l}\text { C. T. Flanigan, } \\
\text { W. P. Moore, } \\
\text { K. C. Fox, C. J. } \\
\text { Distefano }\end{array}$ & POR 4010, Vol. 1 \\
\hline $3.2 \mathrm{a}$ & $\begin{array}{l}\text { Instrumentation } \\
\text { of Tunnel Liners }\end{array}$ & SRI & $\begin{array}{l}\text { W. M. Wells, } \\
\text { F. M. Sauer }\end{array}$ & POR 4010, Vol. 2 \\
\hline $3.2 \mathrm{~b}$ & $\begin{array}{l}\text { Instrumentation } \\
\text { of Tunnel Liners }\end{array}$ & Sandia & $\begin{array}{l}\text { D. G. Palmer, } \\
\text { H. R. Holmes }\end{array}$ & POR 4010, Vol. 3 \\
\hline $3.2 \mathrm{c}$ & $\begin{array}{l}\text { Instrumentation } \\
\text { of Tunnel Liners }\end{array}$ & Omaha Dist., CE & See Project 3.1 & POR 4010, Vol. 4 \\
\hline 3.3 & Shock Spectra & TRW Systems & $\begin{array}{l}\text { F. A. Pieper, } \\
\text { F. W. Galbraith }\end{array}$ & POR 4011 \\
\hline 3.4 & $\begin{array}{l}\text { Motion Photo- } \\
\text { graphy }\end{array}$ & $\begin{array}{l}\text { Edgerton, } \\
\text { Germeshausen \& } \\
\text { Grier (EG\&G) }\end{array}$ & H. L. Smith & POR 4012 \\
\hline 3.5 & $\begin{array}{l}\text { Grouting and } \\
\text { Materials } \\
\text { Control }\end{array}$ & $\begin{array}{l}\text { Waterways Expt. } \\
\text { Sta., CE }\end{array}$ & J. M. Polatty & POR 4013 \\
\hline 3.6 & $\begin{array}{l}\text { Microwave } \\
\text { Doppler }\end{array}$ & $E G \& G$ & R. A. Shunk & POR 4014 \\
\hline 3.7 & $\begin{array}{l}\text { Experiments in } \\
\text { Rock Bolting }\end{array}$ & Omaha Dist., CE & See Project 3.1 & POR 4015 \\
\hline
\end{tabular}


Table 1.1 (Contd.)

\begin{tabular}{|c|c|c|c|c|}
\hline $\begin{array}{l}\text { Project } \\
\text { No. }\end{array}$ & $\begin{array}{l}\text { Project } \\
\text { title }\end{array}$ & Agency & $\begin{array}{l}\text { Project: } \\
\text { officers }\end{array}$ & Report No. \\
\hline 3.8 & $\begin{array}{l}\text { Cable Vulner- } \\
\text { ability Studies }\end{array}$ & $\begin{array}{l}\text { DCA/Bell Tel. } \\
\text { Labs. }\end{array}$ & $\begin{array}{l}\text { H. A. Wells, } \\
\text { A. H. Williamson, } \\
\text { E. F. Witt }\end{array}$ & POR 4016 \\
\hline 4.1 & $\begin{array}{l}\text { Acoustical } \\
\text { Measurements }\end{array}$ & EG\&G & A. E. Villaire & None \\
\hline 6.1 & $\begin{array}{l}\text { Electromagnetic } \\
\text { Pulse Measure- } \\
\text { ments }\end{array}$ & $\begin{array}{l}\text { Air Force } \\
\text { Weapons Lab. }\end{array}$ & $\begin{array}{l}\text { W. D. Hender- } \\
\text { son }\end{array}$ & Deleted $1 / 11 / 66$ \\
\hline $9.3 \mathrm{a}$ & $\begin{array}{l}\text { Design and } \\
\text { Engineering }\end{array}$ & $\begin{array}{l}\text { Holmes and Narver, } \\
\text { Inc. }(\mathrm{H} \& \mathrm{~N})\end{array}$ & $\begin{array}{l}\text { H. F. Haller, } \\
\text { W. H. Wisniski }\end{array}$ & None \\
\hline $9.3 \mathrm{~b}$ & $\begin{array}{l}\text { Design and } \\
\text { Engineering }\end{array}$ & EG\&G & R. A. Shunk & None \\
\hline $9.3 \mathrm{c}$ & $\begin{array}{l}\text { Design and } \\
\text { Engineering }\end{array}$ & $\begin{array}{l}\text { Fenix and } \\
\text { Scisson, Inc. }\end{array}$ & J. Dowling & None \\
\hline $9.3 \mathrm{~d}$ & $\begin{array}{l}\text { Technical } \\
\text { Direction }\end{array}$ & $\begin{array}{l}\text { University of } \\
\text { Illinois }\end{array}$ & J. L. Merritt & POR 4017 \\
\hline $9.3 \mathrm{e}$ & $\begin{array}{l}\text { Conceptual } \\
\text { Development }\end{array}$ & $\begin{array}{l}\text { Newmark, Hansen } \\
\text { and Associates }\end{array}$ & - & DASA 1399 \\
\hline 9.4 & $\begin{array}{l}\text { Construction } \\
\text { and Field } \\
\text { Support }\end{array}$ & $\begin{array}{l}\text { Reynolds Electrical } \\
\text { and Engineering } \\
\text { Co. (REECo) }\end{array}$ & $\begin{array}{l}\text { W. M. Flangas, } \\
\text { G. L. Clayton }\end{array}$ & None \\
\hline 9.7 & $\begin{array}{l}\text { Documentary } \\
\text { Photography }\end{array}$ & $\begin{array}{l}\text { Photo Section, } \\
\text { TC/DASA }\end{array}$ & J.M. Hartnett & None \\
\hline 9.8 & $\begin{array}{l}\text { Motion Picture } \\
\text { Film Reports }\end{array}$ & $\begin{array}{l}\text { USAF, Lookout Mtn. } \\
\text { AF Station }\end{array}$ & S. J. Williams & $\begin{array}{l}\text { "Quick Look" and } \\
\text { "Class A" Documen- } \\
\text { tary Films }\end{array}$ \\
\hline 9.9 & Reports & $\begin{array}{l}\text { Oak Ridge } \\
\text { National Lab. }\end{array}$ & - & - \\
\hline 9.10 & Survey Control & $H \& N$ & See Project 9.3a & - \\
\hline 9.11 & $\begin{array}{l}\text { Timing and } \\
\text { Firing }\end{array}$ & EG\&G & J. Tsitouras & - \\
\hline 9.12 & $\begin{array}{l}\text { Arming and } \\
\text { Device Support }\end{array}$ & Sandia & $\begin{array}{l}\text { R. J. Burton, } \\
\text { H. L. Miller, } \\
\text { M. L. Merritt }\end{array}$ & $\begin{array}{l}\text { Sandia, SC-RR-68- } \\
173\end{array}$ \\
\hline 9.13 & $\begin{array}{l}\text { Reentry } \\
\text { Construction }\end{array}$ & REECo & G. L. Clayton & None \\
\hline 9.14 & $\begin{array}{l}\text { Instrumentation } \\
\text { Timing }\end{array}$ & EG\&G & J. Tsitouras & None \\
\hline 9.15 & Reentry Safety & Sandia & H. L. Rarrick & None \\
\hline - & $\begin{array}{l}\text { Chimney } \\
\text { Exploration }\end{array}$ & $\begin{array}{l}\text { Lawrence Radiation } \\
\text { Laboratory (LRL) }\end{array}$ & C. R. Boardman & $\begin{array}{l}\text { UCRL-50385 (TID } \\
4500, \text { UC-35) }\end{array}$ \\
\hline
\end{tabular}




\section{Appendix 2 \\ Chemical Analyses of Samples from Climax Stock}

Table 2.1 gives chemical analyses of four samples from the Climax stock, and Table 2.2 gives chemical and mineral compositions of material included in spheres of various radii centered at the shot point.

Table 2.1 Chemical analyses ${ }^{\mathrm{a}}$ of samples from southwest part of Climax intrusive, Nye County, Nevada. 39

\begin{tabular}{|c|c|c|c|c|}
\hline Sample No.b & $\mathrm{HG}-7$ & HG-8 & FP-62 & FP-63 \\
\hline Sample material & Granodiorite & Granodiorite & Granodiorite & Quartz monzonite \\
\hline Analysis, wt\%: & & & & \\
\hline $\mathrm{SiO}_{2}$ & 68.6 & 68.2 & 67.5 & 70.8 \\
\hline $\mathrm{Al}_{2} \mathrm{O}_{3}$ & 15.6 & 16.1 & 16.2 & 15.9 \\
\hline $\mathrm{Fe}_{2} \mathrm{O}_{3}$ & 1.7 & 1.7 & 1.9 & 0.6 \\
\hline $\mathrm{FeO}$ & 1.7 & 1.5 & 1.7 & 0.34 \\
\hline $\mathrm{MgO}$ & 0.64 & 0.52 & 0.70 & 0.16 \\
\hline $\mathrm{CaO}$ & 3.6 & 3.3 & 3.9 & 1.8 \\
\hline $\mathrm{Na}_{2} \mathrm{O}$ & 3.1 & 3.1 & 3.2 & 3.0 \\
\hline $\mathrm{K}_{2} \mathrm{O}$ & 3.3 & 3.5 & 3.4 & 5.1 \\
\hline $\mathrm{H}_{2} \mathrm{O}$ & 0.70 & 0.80 & 0.83 & 1.1 \\
\hline $\mathrm{TiO}_{2}$ & 0.38 & 0.40 & 0.46 & 0.22 \\
\hline $\mathrm{P}_{2} \mathrm{O}_{5}$ & 0.18 & 0.18 & 0.18 & 0.13 \\
\hline $\mathrm{MnO}$ & 0.06 & 0.04 & 0.07 & 0.02 \\
\hline $\mathrm{CO}_{2}$ & 0.08 & 0.06 & 0.08 & 0.04 \\
\hline
\end{tabular}

\footnotetext{
${ }^{a}$ Rapid rock analysis by Paul L. D. Elmore, Ivan H. Barlow, Marvin D. Mack, and Samuel D. Botts, Rept. No. IRC-354 (Jan. 19, 1959).

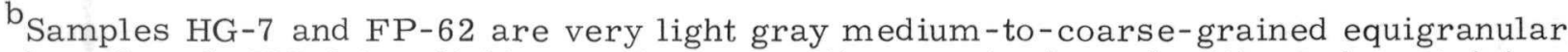
rocks. Sample HG-8 is a light gray fine-to-medium-grained porphyritic rock containing feldspar phenocrysts up to $5 \mathrm{~cm}$ long. Sample FP-63 is similar to FP-62; however, it is a porphyritic rock containing feldspar phenocrysts up to $4 \mathrm{~cm}$ long.
} 
Table 2.2 Bulk mineral and chemical compositions for spheres of rock of selected radii about the Hardhat shot point. ${ }^{7}$ The granodiorite data are based on 19 modal analyses.

\begin{tabular}{|c|c|c|c|c|c|}
\hline Sphere radius (ft) & 50 & 100 & 150 & 200 & 300 \\
\hline $\begin{array}{l}\text { Percent of sphere within } \\
\text { granodiorite intrusive }\end{array}$ & 100 & 100 & 97.5 & 89.7 & 79 \\
\hline \multicolumn{6}{|l|}{ Principal minerals (vol\%): } \\
\hline Quartz & 28 & 28 & 28 & 27.5 & 27.5 \\
\hline Potassium feldspar & 16 & 16 & 16 & 15.0 & 16.5 \\
\hline Plagioclase & 45 & 45 & 45 & 45.5 & 45 \\
\hline Biotite & 9 & 9 & 9 & 9 & 9 \\
\hline Hornblende & Trace & Trace & Trace & Trace & Trace \\
\hline \multicolumn{6}{|l|}{ Chemical analysis $(\mathrm{wt} \%)$ : } \\
\hline $\mathrm{SiO}_{2}$ & 67.6 & 67.6 & 67.8 & 66.6 & 67.8 \\
\hline $\mathrm{Al}_{2} \mathrm{O}_{3}$ & 15.8 & 15.8 & 15.9 & 15.8 & 15.9 \\
\hline $\mathrm{Fe}_{2} \mathrm{O}_{3}$ & 1.8 & 1.8 & 1.8 & 1.7 & 1.7 \\
\hline $\mathrm{FeO}$ & 1.6 & 1.6 & 1.6 & 1.5 & 1.6 \\
\hline $\mathrm{MgO}$ & 0.82 & 0.82 & 0.81 & 0.81 & 0.80 \\
\hline $\mathrm{CaO}$ & 3.7 & 3.7 & 3.7 & 3.7 & 3.6 \\
\hline $\mathrm{Na}_{2} \mathrm{O}$ & 3.1 & 3.1 & 3.1 & 3.1 & 3.1 \\
\hline $\mathrm{K}_{2} \mathrm{O}$ & 3.5 & 3.5 & 3.5 & 3.5 & 3.6 \\
\hline $\mathrm{H}_{2} \mathrm{O}$ & 1.0 & 1.0 & 1.0 & 1.0 & 1.0 \\
\hline $\mathrm{TiO}_{2}$ & 0.39 & 0.39 & 0.39 & 0.4 & 0.39 \\
\hline $\mathrm{P}_{2} \mathrm{O}_{5}$ & 0.18 & 0.18 & 0.18 & 0.18 & 0.18 \\
\hline $\mathrm{MnO}$ & 0.07 & 0.07 & 0.07 & 0.07 & 0.07 \\
\hline $\mathrm{CO}_{2}$ & 0.20 & 0.20 & 0.20 & 0.19 & 0.18 \\
\hline
\end{tabular}




\section{Appendix 3}

\section{Modal Analyses of Mineral Content of Samples from Climax Stock}

Table 3.1 gives the results of modal analyses made on 17 samples from various depths in the U-15a exploration borehole. ${ }^{40}$

Table 3.1 Modal analyses of samples from the U-15a exploration hole in the Climax stock.

\begin{tabular}{|c|c|c|c|c|c|c|c|c|c|c|c|c|c|c|c|c|c|}
\hline Sample depth (ft) & 63 & 160 & 236 & 277 & 321 & 374 & 414 & 477 & 555 & 693 & 739 & 800 & 812 & 833 & 854 & 900 & 1000 \\
\hline Rock type & $\mathrm{QM}^{\mathrm{a}}$ & $\mathrm{G}^{\mathrm{b}}$ & $\mathrm{G}$ & G & G & G & QM & QM & G & G & QM & G & $\mathrm{G}$ & QM & G & G & G \\
\hline \multicolumn{18}{|l|}{ Minerals (vol\%): } \\
\hline $\begin{array}{l}\text { Plagioclase } \\
\quad \text { feldspar } \mathrm{An}_{36} \mathrm{C}\end{array}$ & 50 & 48 & 45 & 47 & 54 & 45 & 39 & 37 & 46 & 40 & 43 & 48 & 49 & 41 & 40 & 54 & 46 \\
\hline $\begin{array}{l}\text { Potassium } \\
\text { feldspar }\end{array}$ & 27 & 17 & 16 & 17 & 14 & 20 & 26 & 24 & 21 & 19 & 22 & 21 & 19 & 25 & 18 & 19 & 17 \\
\hline Quartz & 15 & 25 & 27 & 25 & 21 & 26 & 25 & 25 & 20 & 30 & 27 & 22 & 25 & 26 & 31 & 20 & 27 \\
\hline Biotite & 5 & 8 & 9 & 8 & 7 & 4 & 7 & 11 & 9 & 9 & 5 & 6 & 5 & 6 & 8 & 4 & 7 \\
\hline Chlorite & 2 & 1 & 2 & 2 & 2 & 4 & 1. & 2 & 2 & Tr. & 2 & 1 & 1 & 1 & $\operatorname{Tr}$. & 1 & 2 \\
\hline Hornblende & Tr. ${ }^{d}$ & $\operatorname{Tr}$ & Tr. & $\operatorname{Tr}$. & - & Tr. & $\operatorname{Tr}$. & $\operatorname{Tr}$ & Tr. & 1 & Tr. & Tr. & Tr. & $\operatorname{Tr}$. & $\operatorname{Tr}$ & $\operatorname{Tr}$. & $\operatorname{Tr}$. \\
\hline Allanite & $\operatorname{Tr}$ & - & Tr. & $\operatorname{Tr}$. & - & $\operatorname{Tr}$ & - & - & - & $\operatorname{Tr}$. & - & - & - & $\operatorname{Tr}$. & - & - & $\operatorname{Tr}$. \\
\hline Pyrite & - & $\operatorname{Tr}$. & $\operatorname{Tr}$ & Tr. & $\operatorname{Tr}$. & Tr. & - & - & Tr. & - & - & - & - & - & - & $\operatorname{Tr}$. & - \\
\hline Hydrous iron oxide & - & $\operatorname{Tr}$. & - & - & - & - & - & - & - & - & - & - & - & - & - & - & - \\
\hline $\begin{array}{l}\text { Sphene } \\
\text { Apatite } \\
\text { Zircon } \\
\text { Magnetite } \\
\text { Myrmekite } \\
\text { Sericite } \\
\text { Calcite } \\
\text { Clinozoisite } \\
\text { Epidote } \\
\text { Clay (unidentified) }\end{array}$ & & Each & $f$ thes & e cons & titute & ts oc & furs ir & trace & amol & ints ( & $1 \%$ ) in & all tl & in $\mathrm{sec}$ & tions & & & \\
\hline
\end{tabular}




\section{Appendix 4}

\section{Porosity, Density, Water Content, and Sonic Velocity of Samples from Climax Stock at Various Depths}

Table 4.1 gives a statistical summary of porosity and density for samples in the Climax stock. Table 4.2 gives porosity, water content, and sonic velocity for the more electrically resistive zones in various holes in the Climax stock.

Table 4.1 Statistical summary of porosity and density of 26 Climax granite samples from the U-15a borehole, Area 15, Nye County, Nevada. 40

Percent porosity:

Arithmetic mean

0.9

1 standard deviation

$\pm 0.9$

2 standard errors of mean

$\pm 0.3$

Density, bulk (g/cc):

Arithmetic mean

2.67

1 standard deviation

$\pm 0.02$

2 standard errors of mean

$\pm 0.02$

Density, grain $(\mathrm{g} / \mathrm{cc})$ :

Arithmetic mean

1 standard deviation

$\pm 0.02$

2 standard errors of mean

$\pm 0.02$

Density, powder $(\mathrm{g} / \mathrm{cc})$ :

Arithmetic mean

2.69

1 standard deviation

$\pm 0.01$

2 standard errors of mean

$\pm 0.005$ 
Table 4.2 Porosity and water content (both derived from electrical resistivity) and sonic velocity for the more electrically resistive zones of various drill holes in granite at the Nevada Test Site, Nye County, Nevada. (Interpretations by G. E. Manger of USGS.)

\begin{tabular}{|c|c|c|c|c|}
\hline Hole No. & $\begin{array}{l}\text { Depth } \\
\text { interval (ft) }\end{array}$ & $\begin{array}{c}\text { Porosity, } \\
(\%)\end{array}$ & $\begin{array}{l}\text { Water content of } \\
\text { pores, },(\%)\end{array}$ & $\begin{array}{c}\text { Sonic } \\
\text { velocity }(\mathrm{ft} / \mathrm{sec})\end{array}$ \\
\hline \multirow[t]{4}{*}{33} & $90-114$ & 17.8 & $109(59)^{\mathrm{C}}$ & 16,350 \\
\hline & $461-520$ & 9.5 & $100(25)^{\mathrm{C}}$ & 18,360 \\
\hline & $720-760$ & 12.8 & 109 & 17,630 \\
\hline & $793-853$ & 12.7 & 101 & 17,930 \\
\hline \multirow[t]{6}{*}{34} & $105-149$ & 10.6 & 110 & 17,010 \\
\hline & $154-178$ & 6.4 & 105 & 18,370 \\
\hline & $286-314$ & 8.5 & 98 & 18,290 \\
\hline & $400-424$ & 6.6 & 96 & 18,640 \\
\hline & $735-778$ & 8.5 & 98 & 17,990 \\
\hline & $869-908$ & 5.4 & 84 & 19,020 \\
\hline \multirow[t]{4}{*}{35} & $335-377$ & $1.4-$ & $80+$ & 18,890 \\
\hline & $468-510$ & 2.3 & 77 & 18,930 \\
\hline & $603-627$ & 1.7 & 73 & 18,430 \\
\hline & $770-798$ & 1.7 & 100 & $\leftarrow^{d}$ \\
\hline \multirow[t]{3}{*}{37} & $255-279$ & 3.9 & 57 & 19,080 \\
\hline & $316-340$ & 4.1 & 53 & 18,820 \\
\hline & $460-498$ & 2.2 & 88 & 18,100 \\
\hline \multirow[t]{20}{*}{38} & $194-217$ & 9.0 & 89 & 18,150 \\
\hline & $266-309$ & 7.6 & 80 & 18,360 \\
\hline & $323-363$ & 4.3 & 60 & 18,950 \\
\hline & $374-399$ & 2.9 & 78 & 18,960 \\
\hline & $442-487$ & 3.4 & 77 & 18,800 \\
\hline & $590-614$ & 4.9 & 91 & 18,700 \\
\hline & $800-854$ & 2.9 & 69 & 18,800 \\
\hline & $862-913$ & 2.0 & 74 & 18,890 \\
\hline & $972-1020$ & 1.9 & 80 & 19,150 \\
\hline & $1118-1143$ & 3.2 & 49 & 18,710 \\
\hline & $1170-1211$ & 2.2 & 68 & 18,800 \\
\hline & $1280-1333$ & 2.4 & 61 & 18,840 \\
\hline & $1376-1414$ & 2.6 & 53 & 18,850 \\
\hline & $1451-1493$ & 2.7 & 46 & 18,830 \\
\hline & $1515-1554$ & 2.7 & 65 & 18,340 \\
\hline & $1578-1606$ & 2.1 & 78 & 18,520 \\
\hline & $1660-1697$ & 2.7 & 78 & 18,500 \\
\hline & $1711-1751$ & 3.2 & 68 & 18,900 \\
\hline & $1770-1820$ & 3.2 & 61 & 18,520 \\
\hline & $1845-1913$ & 2.4 & 73 & 18,530 \\
\hline \multirow[t]{3}{*}{31} & $275-320$ & 1.05 & $-{ }^{d}$ & $20,400^{\mathrm{e}}$ \\
\hline & $1060-1075$ & 0.7 (?) & $-^{d}$ & $-^{\mathrm{d}}$ \\
\hline & \multicolumn{4}{|c|}{$\begin{array}{l}\text { Average sonic velocity of the more resistive zones from } \\
450 \text { to } 940 \mathrm{ft} \text { in drill hole U-15a is by inspection } \\
20,800 \mathrm{ft} / \mathrm{sec} \text {. Corresponding porosity obtained from } \\
\text { cores is probably } 0.9 \% \text {. }\end{array}$} \\
\hline
\end{tabular}

\footnotetext{
a Derived from the 16 -in. normal resistivity.

${ }^{b}$ Derived from the resistivity of the $16-$ in. normal log and 19-ft lateral log.

${ }^{c}$ Derived from the SP $l o g$.

$\mathrm{d}_{\text {Not determined. }}$

e $\mathrm{By}$ inspection.
} 


\section{Appendix 5}

\section{Stress Measurements from Piledriver Event}

Table 5.1 gives calculated and observed stresses and strains at various stations for the Piledriver event. Figure 5.1 shows peak radial stresses measured in holes A-E. (See Fig. 2 for layout of stations and holes in Piledriver event.)

Table 5.1 Radial stresses and strains calculated and observed for Piledriver event. ${ }^{10}$

\begin{tabular}{lccccccc}
\hline \multirow{2}{*}{ Station } & \multicolumn{2}{c}{ Slant } & \multicolumn{2}{c}{ range } & \multicolumn{2}{c}{ Stress $(\mathrm{kb})$} & \multicolumn{2}{c}{ Strain $(\%)$} \\
\hline Y-SL & 386 & 117.7 & 7.7 & - & 1.5 & Obs. \\
A-SL & 473 & 144.2 & 4.1 & - & 0.8 & - \\
B-SL & 668 & 203.6 & 3.9 & 1.2 & 0.76 & - \\
D-SL & 833 & 253.9 & 1.8 & - & 0.35 & - \\
C-SL & 932 & 284.1 & 1.3 & - & 0.26 & - \\
16-SL & 1543 & 470.4 & 0.59 & - & 0.11 & - \\
\hline
\end{tabular}

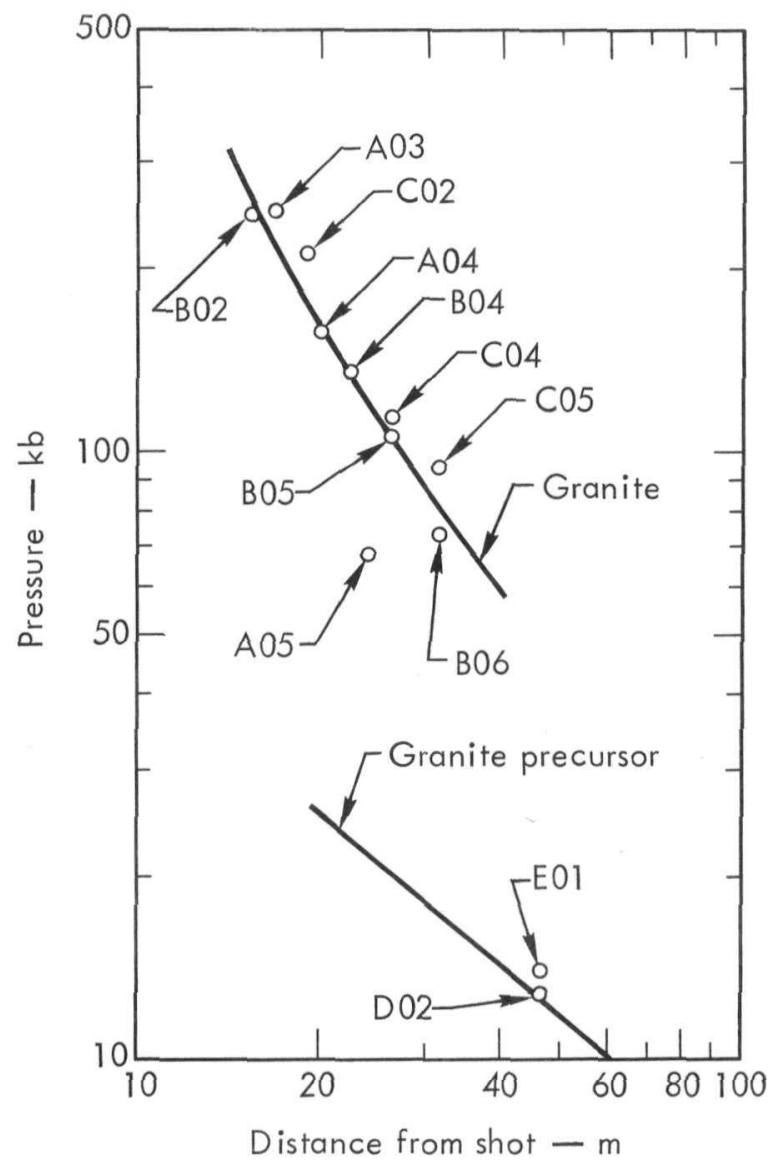

Fig. 5.1. Measured shock pressure vs distance from shot point for Piledriver event. 12 


\section{Appendix 6 \\ Strikes and Dips of Preexisting Joint Sets in the CR Drift}

Table 6.1 gives the orientation and number of fractures and/or joints in the CR lateral drift. Table 6.2 gives similar information for the CR north drift.

Table 6.1 Strikes and dips of joint sets in the CR lateral drift ${ }^{29}$ (see Fig. 2 for location). For each station and joint set, the upper value is average strike and the lower value is average dip. The number of measurements included in the average is shown in parentheses.

\begin{tabular}{|c|c|c|c|c|c|c|c|c|c|}
\hline \multirow[b]{2}{*}{ Station } & \multicolumn{9}{|c|}{ Strikes and dips of joint sets A through I } \\
\hline & A & B & C & D & $\mathrm{E}$ & $\bar{F}$ & $\overline{\mathrm{G}}$ & $\mathrm{H}$ & I \\
\hline $0+20$ & $\begin{array}{l}\text { N53W(12) } \\
27 \mathrm{NE}(12)\end{array}$ & $\begin{array}{l}\text { N62W(13) } \\
88 \mathrm{SW}(13)\end{array}$ & $\begin{array}{l}\text { N32E(4) } \\
77 \mathrm{NW}(4)\end{array}$ & $\begin{array}{l}\text { N72E(2) } \\
62 \mathrm{SE}(2)\end{array}$ & $=$ & z & - & - & $\begin{array}{l}\text { N40W(1) } \\
\text { Vert (1) }\end{array}$ \\
\hline $0+30$ & $\begin{array}{l}\mathrm{N} 50 \mathrm{~W}(5) \\
28 \mathrm{NE}(5)\end{array}$ & $\begin{array}{l}\text { N68W(7) } \\
83 \mathrm{SW}(7)\end{array}$ & $\begin{array}{l}\text { N31 E(3) } \\
62 N W(3)\end{array}$ & $\begin{array}{l}\text { N72E(3) } \\
64 \mathrm{SE}(3)\end{array}$ & $\begin{array}{l}\text { N55E(1) } \\
46 \text { NW(1) }\end{array}$ & - & - & 二 & $\begin{array}{l}\text { N41W(4) } \\
89 \mathrm{NE}(1)\end{array}$ \\
\hline $0+40$ & $\begin{array}{l}\text { N50W(5) } \\
29 \mathrm{NE}(5)\end{array}$ & $\begin{array}{l}\text { N67W(5) } \\
\text { Vert(5) }\end{array}$ & $\begin{array}{l}\mathrm{N} 19 \mathrm{E}(4) \\
66 \mathrm{NW}(4)\end{array}$ & $\begin{array}{l}\text { N82E(1) } \\
69 \operatorname{SE}(4)\end{array}$ & $\begin{array}{l}\text { N50E(6) } \\
57 \text { NW(6) }\end{array}$ & - & - & - & $\begin{array}{l}\text { N41W(3) } \\
89 \mathrm{NE}(3)\end{array}$ \\
\hline $0+50$ & $\begin{array}{l}\text { N44W(3) } \\
32 \mathrm{NE}(3)\end{array}$ & $\begin{array}{l}\text { N75W(3) } \\
85 \mathrm{NE}(3)\end{array}$ & $\begin{array}{l}\text { N19E(1) } \\
66 \mathrm{NW}(1)\end{array}$ & $\overline{-}$ & $\begin{array}{l}\text { N46E(6) } \\
57 \mathrm{NW}(2)\end{array}$ & $\begin{array}{c}\text { N38W(1) } \\
-\end{array}$ & - & - & $\begin{array}{l}\text { N29W(1) } \\
80 \text { SW(1) }\end{array}$ \\
\hline $0+60$ & $\begin{array}{l}\text { N50W(8) } \\
26 \mathrm{NE}(8)\end{array}$ & $\begin{array}{l}\text { N78W(4) } \\
79 \mathrm{SW}(4)\end{array}$ & $\begin{array}{l}\mathrm{N} 21 \mathrm{E}(3) \\
76 \mathrm{NW}(3)\end{array}$ & $\begin{array}{l}\text { N85E(3) } \\
74 \mathrm{SE}(3)\end{array}$ & $\begin{array}{l}\mathrm{N} 46 \mathrm{E}(6) \\
61 \mathrm{NW}(6)\end{array}$ & $\begin{array}{l}\text { N38W(1) } \\
48 \mathrm{NE}(1)\end{array}$ & - & - & $\begin{array}{l}\text { N8W(1) } \\
77 \mathrm{SW}(1)\end{array}$ \\
\hline $0+70$ & $\begin{array}{l}\text { N48W(7) } \\
29 \mathrm{NE}(7)\end{array}$ & $\begin{array}{l}\text { N79W(4) } \\
78 \mathrm{SW}(4)\end{array}$ & $\begin{array}{l}\text { N13E(5) } \\
68 N W(5)\end{array}$ & $\begin{array}{l}\text { N80E(1) } \\
71 \mathrm{SE}(1)\end{array}$ & $\begin{array}{l}\text { N49E(9) } \\
56 \text { NW(9) }\end{array}$ & $\begin{array}{l}\text { N38W(1) } \\
48 \mathrm{NE}(1)\end{array}$ & $6 \overline{5 \mathrm{SE}}(8)$ & - & - \\
\hline $0+80$ & $\begin{array}{l}\text { N48W(5) } \\
29 N E(5)\end{array}$ & $\begin{array}{l}\text { N73W(7) } \\
84 \mathrm{SW}(7)\end{array}$ & $\begin{array}{l}\text { N13E(3) } \\
66 \mathrm{NW}(3)\end{array}$ & - & $\begin{array}{l}\text { N45E(5) } \\
55 N W(5)\end{array}$ & - & $\begin{array}{l}\text { N35E(14) } \\
67 \mathrm{SE}(14)\end{array}$ & - & - \\
\hline $0+90$ & $\begin{array}{l}\text { N50W(5) } \\
30 \mathrm{NE}(5)\end{array}$ & $\begin{array}{l}\text { N73W(10) } \\
88 \text { SW(10) }\end{array}$ & - & - & $\begin{array}{l}\text { N44E(8) } \\
55 \mathrm{NW}(8)\end{array}$ & - & - & $\overline{-}$ & $\overline{-}$ \\
\hline $1+00$ & $\begin{array}{l}\text { N53W(7) } \\
29 N E(7)\end{array}$ & $\begin{array}{l}\text { N74W(2) } \\
\text { Vert(2) }\end{array}$ & $\begin{array}{l}\text { N10E(5) } \\
74 \text { NW(5) }\end{array}$ & - & $\begin{array}{l}\text { N45E(2) } \\
55 \mathrm{NW}(2)\end{array}$ & - & $\begin{array}{l}\text { N41 E(2) } \\
84 \operatorname{SE}(2)\end{array}$ & - & - \\
\hline $1+10$ & $\begin{array}{l}\text { N49W(8) } \\
31 \mathrm{NE}(8)\end{array}$ & $\begin{array}{l}\text { N80W(2) } \\
\text { Vert(2) }\end{array}$ & $\begin{array}{l}\text { N12E(12) } \\
75 N W(12)\end{array}$ & - & 二 & - & - & - & - \\
\hline $1+20$ & $\begin{array}{l}\mathrm{N} 61 \mathrm{~W}(10) \\
25 \mathrm{NE}(10)\end{array}$ & $\begin{array}{l}\text { N81W(16) } \\
89 S W(16)\end{array}$ & $\begin{array}{l}\text { N10E(9) } \\
67 N W(9)\end{array}$ & - & - & - & $\begin{array}{l}\mathrm{N} 41 \mathrm{E}(2) \\
75 \mathrm{SE}(2)\end{array}$ & - & $\begin{array}{l}\mathrm{N} 22 \mathrm{~W}(2) \\
74 \mathrm{SW}(2)\end{array}$ \\
\hline $1+30$ & $\begin{array}{l}\text { N49W(4) } \\
39 \mathrm{NE}(4)\end{array}$ & $\begin{array}{l}\text { N83W(1) } \\
\text { Vert(1) }\end{array}$ & - & - & - & - & - & - & $\begin{array}{l}\mathrm{N} 27 \mathrm{~W}(3) \\
79 \mathrm{SW}(3)\end{array}$ \\
\hline $1+40$ & $\begin{array}{l}\text { N49W(7) } \\
30 \mathrm{NE}(7)\end{array}$ & $\begin{array}{l}\text { N79W(3) } \\
\text { Vert(3) }\end{array}$ & $\begin{array}{l}\text { N13E(1) } \\
59 \mathrm{NW}(1)\end{array}$ & - & $\overline{-}$ & - & $\begin{array}{l}\text { N33E(1) } \\
65 \mathrm{SE}(1)\end{array}$ & $\overline{-}$ & $\overline{-}$ \\
\hline $1+50$ & $\begin{array}{l}\text { N49W(5) } \\
30 \mathrm{NE}(5)\end{array}$ & $\begin{array}{l}\mathrm{N} 72 \mathrm{~W}(1) \\
88 \mathrm{NE}(1)\end{array}$ & - & - & - & - & - & - & - \\
\hline $1+60$ & $\begin{array}{l}\text { N51W(7) } \\
31 \mathrm{NE}(7)\end{array}$ & $\begin{array}{l}\mathrm{N} 76 \mathrm{~W}(7) \\
87 \mathrm{NE}(7)\end{array}$ & - & $\begin{array}{l}\text { N54E(1) } \\
73 \mathrm{SE}(1)\end{array}$ & $\overline{-}$ & - & $\begin{array}{l}\text { N26E(1) } \\
65 \mathrm{SE}(1)\end{array}$ & $\begin{array}{l}\text { N53W(1) } \\
65 \mathrm{SE}(1)\end{array}$ & $\begin{array}{l}\mathrm{N} 23 \mathrm{~W}(2) \\
85 \mathrm{SW}(2)\end{array}$ \\
\hline $1+70$ & $\begin{array}{l}\mathrm{N} 52 \mathrm{~W}(6) \\
31 \mathrm{NE}(6)\end{array}$ & $\begin{array}{l}\mathrm{N} 70 \mathrm{~W}(10) \\
84 \mathrm{NE}(10)\end{array}$ & 二 & - & $\overline{-}$ & - & $\begin{array}{l}\text { N52E(9) } \\
68 \mathrm{SE}(9)\end{array}$ & - & - \\
\hline $1+80$ & $\begin{array}{l}\mathrm{N} 51 \mathrm{~W}(3) \\
27 \mathrm{NE}(3)\end{array}$ & $\begin{array}{l}\text { N65W(9) } \\
\text { Vert(9) }\end{array}$ & - & - & $\begin{array}{l}\text { N55E(2) } \\
54 \mathrm{NW}(2)\end{array}$ & - & $\begin{array}{l}\text { N48W(5) } \\
55 \operatorname{SE}(5)\end{array}$ & - & - \\
\hline $1+90$ & $\begin{array}{l}\text { N49W(4) } \\
28 \mathrm{NE}(4)\end{array}$ & $\begin{array}{l}\text { N64W(8) } \\
88 \mathrm{NE}(8)\end{array}$ & $\begin{array}{l}\mathrm{N} 12 \mathrm{E}(3) \\
48 \mathrm{NW}(3)\end{array}$ & - & - & - & $\begin{array}{l}\text { N46E(4) } \\
51 \mathrm{SE}(4)\end{array}$ & - & $\overline{-}$ \\
\hline $2+00$ & $\begin{array}{l}\text { N52W(1) } \\
24 \mathrm{NE}(1)\end{array}$ & $\begin{array}{l}\text { N61W(3) } \\
\text { Vert(3) }\end{array}$ & $\begin{array}{l}\text { N9E(2) } \\
50 N W(2)\end{array}$ & - & - & - & $\begin{array}{l}\text { N42E(3) } \\
60 \mathrm{SE}(3)\end{array}$ & $\begin{array}{l}\text { N75W(1) } \\
65 \mathrm{NE}(1)\end{array}$ & - \\
\hline $2+10$ & $\begin{array}{l}\text { N48W(5) } \\
30 N E(5)\end{array}$ & $\begin{array}{l}\text { N71W(6) } \\
79 \mathrm{SW}(6)\end{array}$ & $\begin{array}{l}\text { N30E(1) } \\
46 \mathrm{NW}(1)\end{array}$ & - & $\begin{array}{l}\text { N60E(1) } \\
35 N W(1)\end{array}$ & $\begin{array}{l}\text { N43W(4) } \\
59 \mathrm{NE}(4)\end{array}$ & - & $\begin{array}{l}\text { N87W(1) } \\
59 \mathrm{NE}(1)\end{array}$ & - \\
\hline $2+19$ & $\begin{array}{l}\text { N47W(4) } \\
30 \mathrm{NE}(4)\end{array}$ & $\begin{array}{l}\text { N73W(4) } \\
88 \text { SW(4) }\end{array}$ & - & - & $\begin{array}{l}\text { N30E(1) } \\
46 N W(1)\end{array}$ & $\overline{-}$ & $\begin{array}{l}\text { N42E(1) } \\
59 \operatorname{SE}(1)\end{array}$ & $\begin{array}{l}\text { N87W(1) } \\
59 \mathrm{NE}(1)\end{array}$ & $\begin{array}{l}\text { N47W(1) } \\
89 S W(1)\end{array}$ \\
\hline $\begin{array}{l}\text { Mean } \\
\text { values }\end{array}$ & $\begin{array}{l}\text { N50W(121) } \\
29 \mathrm{NE}(121)\end{array}$ & $\begin{array}{l}\text { N73W(125) } \\
89 S W(125)\end{array}$ & $\begin{array}{l}\text { N12E(56) } \\
68 N W(56)\end{array}$ & $\begin{array}{l}\mathrm{N} 80 \mathrm{E}(11) \\
69 \mathrm{SE}(15)\end{array}$ & $\begin{array}{l}\text { N46E(47) } \\
56 \mathrm{NW}(47)\end{array}$ & $\begin{array}{l}-(7) \\
-(7)\end{array}$ & $\begin{array}{l}\text { N42E(42) } \\
65 \operatorname{SE}(50)\end{array}$ & $\begin{array}{l}-(4) \\
-(4)\end{array}$ & $\begin{array}{l}-(18) \\
-(18)\end{array}$ \\
\hline
\end{tabular}


Table 6.2 Strikes and dips of joint sets in the CR north drift ${ }^{29}$ (see Fig. 2 for location). For each station and joint set, the upper value is average strike and the lower value is average dip. The number of measurements included in the average is shown in parentheses.

\begin{tabular}{|c|c|c|c|c|c|c|c|c|c|}
\hline \multirow[b]{2}{*}{ Station } & \multicolumn{9}{|c|}{ Strikes and dips of joint sets A through I } \\
\hline & A & $\overline{\mathrm{B}}$ & $\mathrm{C}$ & $\mathrm{D}$ & E & $\mathrm{F}$ & G & $\mathrm{H}$ & $\mathrm{I}$ \\
\hline $0+60$ & $\begin{array}{l}\mathrm{N} 41 \mathrm{~W}(3) \\
34 \mathrm{NE}(3)\end{array}$ & $\begin{array}{l}\mathrm{N} 68 \mathrm{~W}(4) \\
86 \mathrm{NE}(4)\end{array}$ & $\begin{array}{l}\mathrm{N} 22 \mathrm{E}(3) \\
89 \mathrm{SE}(3)\end{array}$ & - & $\begin{array}{l}\text { N35E(3) } \\
62 \mathrm{NW}(3)\end{array}$ & - & $\begin{array}{l}\text { N35E(3) } \\
63 \mathrm{SE}(3)\end{array}$ & $\overline{-}$ & $\overline{-}$ \\
\hline $1+70$ & $\begin{array}{l}\mathrm{N} 41 \mathrm{~W}(4) \\
34 \mathrm{NE}(4)\end{array}$ & $\begin{array}{l}\text { N70W(2) } \\
86 \mathrm{NE}(2)\end{array}$ & - & - & $\begin{array}{l}\mathrm{N} 41 \mathrm{E}(5) \\
58 \mathrm{NW}(5)\end{array}$ & - & $\begin{array}{l}\mathrm{N} 39 \mathrm{E}(3) \\
86 \mathrm{SE}(3)\end{array}$ & 二 & $\begin{array}{l}\mathrm{N} 15 \mathrm{~W}(2) \\
85 \mathrm{SW}(2)\end{array}$ \\
\hline $1+80$ & $\begin{array}{l}\mathrm{N} 54 \mathrm{~W}(7) \\
31 \mathrm{NE}(7)\end{array}$ & $\begin{array}{l}\text { N55W(1) } \\
\text { Vert(1) }\end{array}$ & - & $\overline{-}$ & $\begin{array}{l}\text { N57E(1) } \\
80 \mathrm{NW}(1)\end{array}$ & - & $\begin{array}{l}\text { N36E(8) } \\
\text { Vert(8) }\end{array}$ & $\overline{-}$ & - \\
\hline $1+90$ & $\begin{array}{l}\text { N53W(7) } \\
31 \mathrm{NE}(7)\end{array}$ & $\begin{array}{l}\mathrm{N} 62 \mathrm{~W}(5) \\
88 \mathrm{NE}(5)\end{array}$ & - & - & - & - & $\begin{array}{l}\text { N40E(16) } \\
88 \mathrm{SE}(16)\end{array}$ & - & $\begin{array}{l}\mathrm{N} 41 \mathrm{~W}(2) \\
83 \mathrm{SW}(2)\end{array}$ \\
\hline $2+00$ & $\begin{array}{l}\mathrm{N} 50 \mathrm{~W}(7) \\
31 \mathrm{NE}(7)\end{array}$ & - & - & - & $\begin{array}{l}\mathrm{N} 50 \mathrm{E}(1) \\
51 \mathrm{NW}(1)\end{array}$ & - & $\begin{array}{l}\mathrm{N} 35 \mathrm{E}(2) \\
79 \mathrm{SE}(2)\end{array}$ & 二 & $\begin{array}{l}\mathrm{N} 49 \mathrm{~W}(1) \\
84 \mathrm{SW}(1)\end{array}$ \\
\hline $2+10$ & $\begin{array}{l}\text { N53W(8) } \\
31 \mathrm{NE}(8)\end{array}$ & - & $\begin{array}{l}\text { N30E(1) } \\
50 \mathrm{NW}(1)\end{array}$ & - & $\begin{array}{l}\text { N48E(4) } \\
54 \mathrm{NW}(4)\end{array}$ & $\overline{-}$ & $\begin{array}{l}\mathrm{N} 42 \mathrm{E}(3) \\
74 \mathrm{SE}(3)\end{array}$ & $\overline{-}$ & $\begin{array}{l}\text { N16W(3) } \\
78 \mathrm{NE}(3)\end{array}$ \\
\hline $2+20$ & $\begin{array}{l}\mathrm{N} 51 \mathrm{~W}(6) \\
35 \mathrm{NE}(6)\end{array}$ & - & - & $\begin{array}{l}\text { N84E(5) } \\
85 \operatorname{SE}(5)\end{array}$ & $\begin{array}{l}\mathrm{N} 50 \mathrm{E}(3) \\
58 \mathrm{NW}(3)\end{array}$ & 二 & $\begin{array}{l}\mathrm{N} 44 \mathrm{E}(1) \\
87 \mathrm{SE}(1)\end{array}$ & $\overline{-}$ & $\begin{array}{l}\mathrm{N} 10 \mathrm{~W}(1) \\
87 \mathrm{NW}(1)\end{array}$ \\
\hline $2+30$ & $\begin{array}{l}\text { N54W(1) } \\
30 \mathrm{NE}(10)\end{array}$ & 二 & - & $\begin{array}{l}\text { N88E(4) } \\
86 \mathrm{SE}(4)\end{array}$ & $\begin{array}{l}\mathrm{N} 50 \mathrm{E}(4) \\
58 \mathrm{NW}(4)\end{array}$ & $\begin{array}{l}\mathrm{N} 21 \mathrm{~W}(1) \\
52 \mathrm{NE}(1)\end{array}$ & $\begin{array}{l}\text { N30E(1) } \\
85 \mathrm{NE}(1)\end{array}$ & $=$ & $\begin{array}{l}\mathrm{N} 7 \mathrm{~W}(10) \\
85 \mathrm{SW}(10)\end{array}$ \\
\hline $2+38$ & $\begin{array}{l}\text { N54W(6) } \\
31 \mathrm{NE}(6)\end{array}$ & - & - & $\overline{-}$ & $\overline{-}$ & - & - & $=$ & $\begin{array}{l}\text { N9W(15) } \\
87 \text { SW(15) }\end{array}$ \\
\hline $\begin{array}{l}\text { Mean } \\
\text { values }\end{array}$ & $\begin{array}{l}\mathrm{N} 51.3 \mathrm{~W}(58) \\
31.5 \mathrm{NE}(58)\end{array}$ & $\begin{array}{l}\mathrm{N} 64.7 \mathrm{~W}(12) \\
87.1 \mathrm{NE}(12)\end{array}$ & $\begin{array}{l}\mathrm{N} 22 \mathrm{E}(4) \\
89 \mathrm{SE}(4)\end{array}$ & $\begin{array}{l}\text { N86E(9) } \\
85 \operatorname{SE}(9)\end{array}$ & $\begin{array}{l}\text { N45.6E(21) } \\
59 \mathrm{NW}(21)\end{array}$ & $\begin{array}{l}-(1) \\
-(1)\end{array}$ & $\begin{array}{l}\mathrm{N} 38.1 \mathrm{E}(37) \\
84.5 \mathrm{SE}(37)\end{array}$ & $=$ & $\begin{array}{l}\mathrm{N} 9.4 \mathrm{~W}, \mathrm{~N} 46 \mathrm{~W} \\
87.6 \mathrm{SW}, 83 \mathrm{SW}\end{array}$ \\
\hline
\end{tabular}




\section{Appendix 7 \\ Photographs of Cores from Hole U-15.01 PS-1}

Total depth $423.8 \mathrm{ft}$.

Overall core recovery $89.4 \%$. 


$$
\text { PS-1 }
$$

Depth in hole: $0-53.4 \mathrm{ft}$

Distance from shot point: $287-328 \mathrm{ft}$
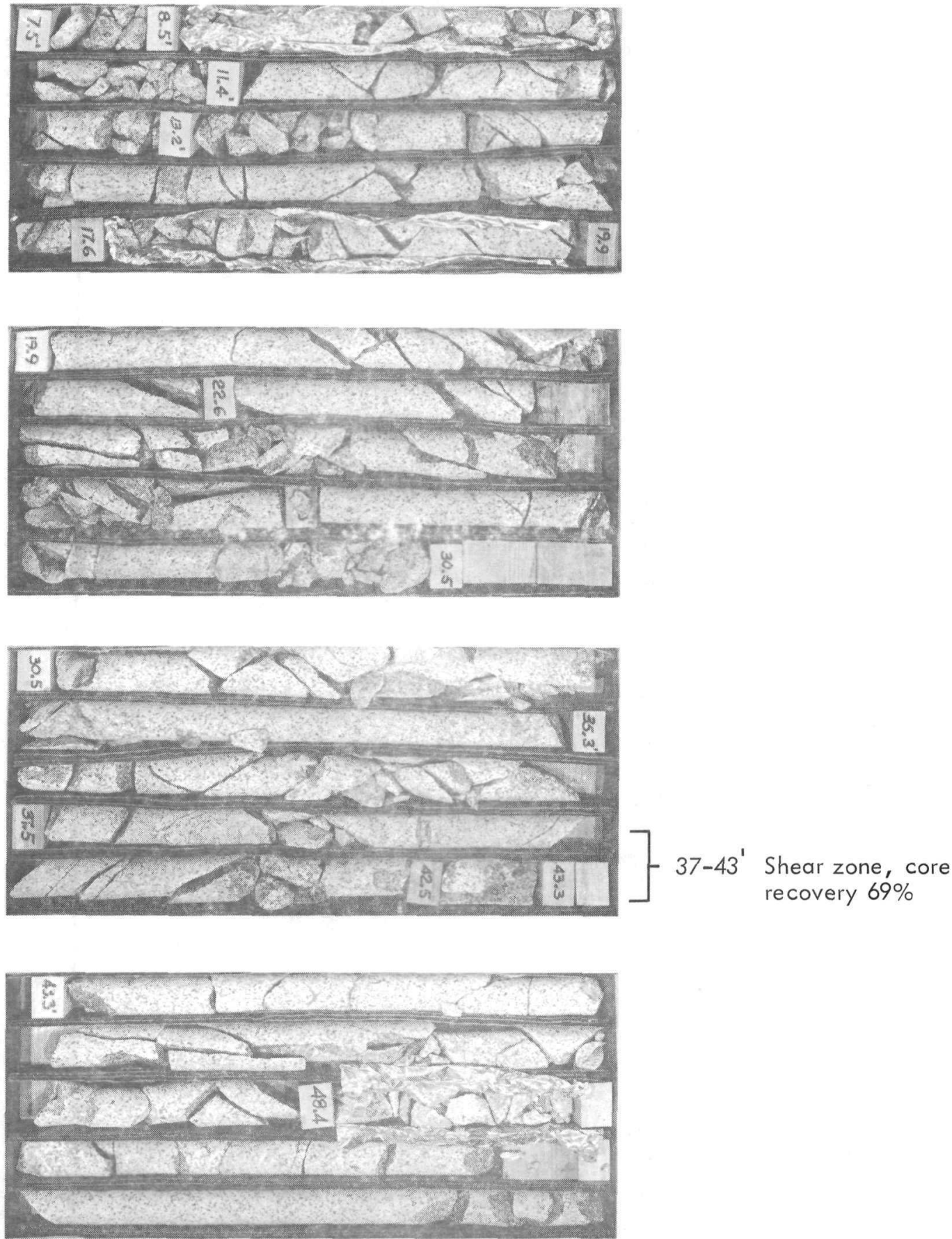
PS -1

Depth in hole: $53.4-95.3 \mathrm{ft}$

Distance from shot point: $250-287 \mathrm{ft}$
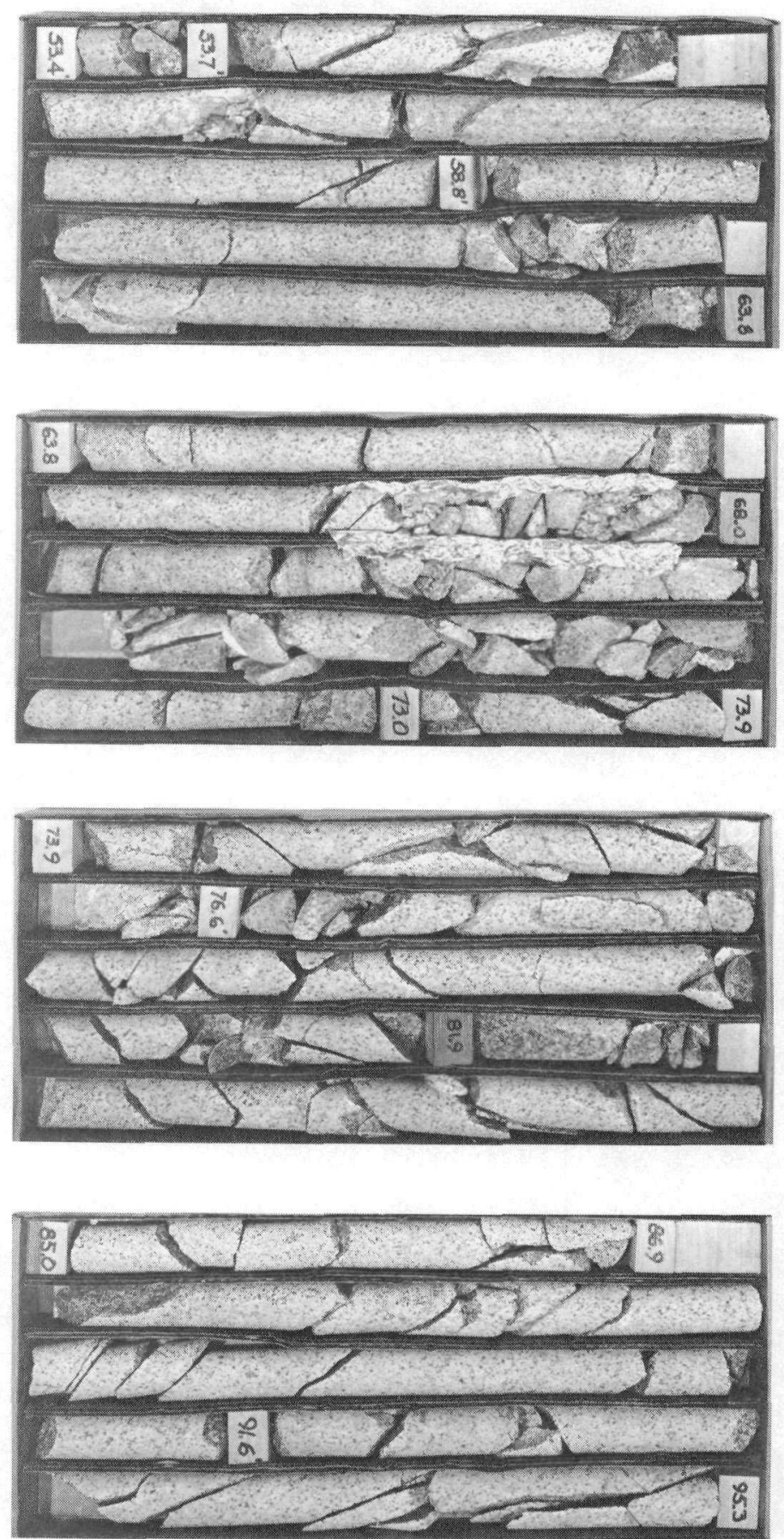
PS -1

Depth in hole: $95.3-141.2 \mathrm{ft}$

Distance from shot point: $218-250 \mathrm{ft}$

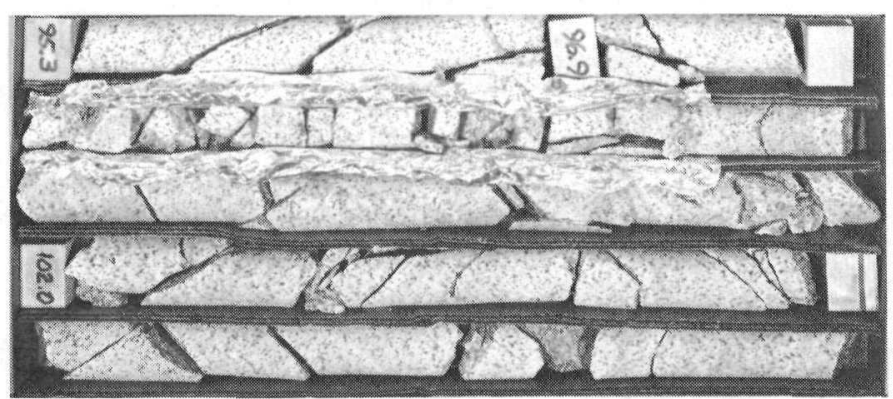

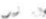
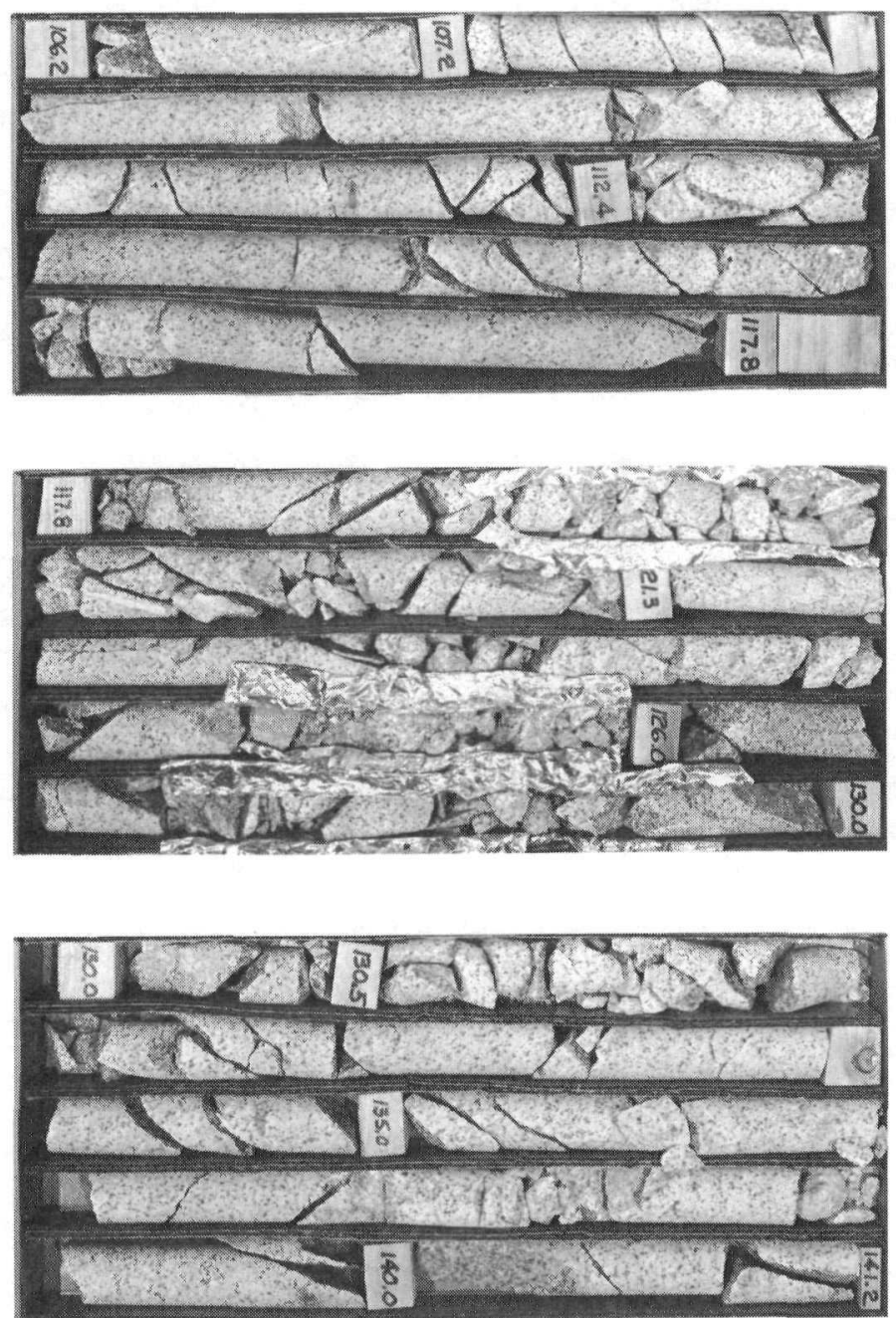
PS - 1

Depth in hole: $141.2-189.7 \mathrm{ft}$

Distance from shot point: $188-218 \mathrm{ft}$
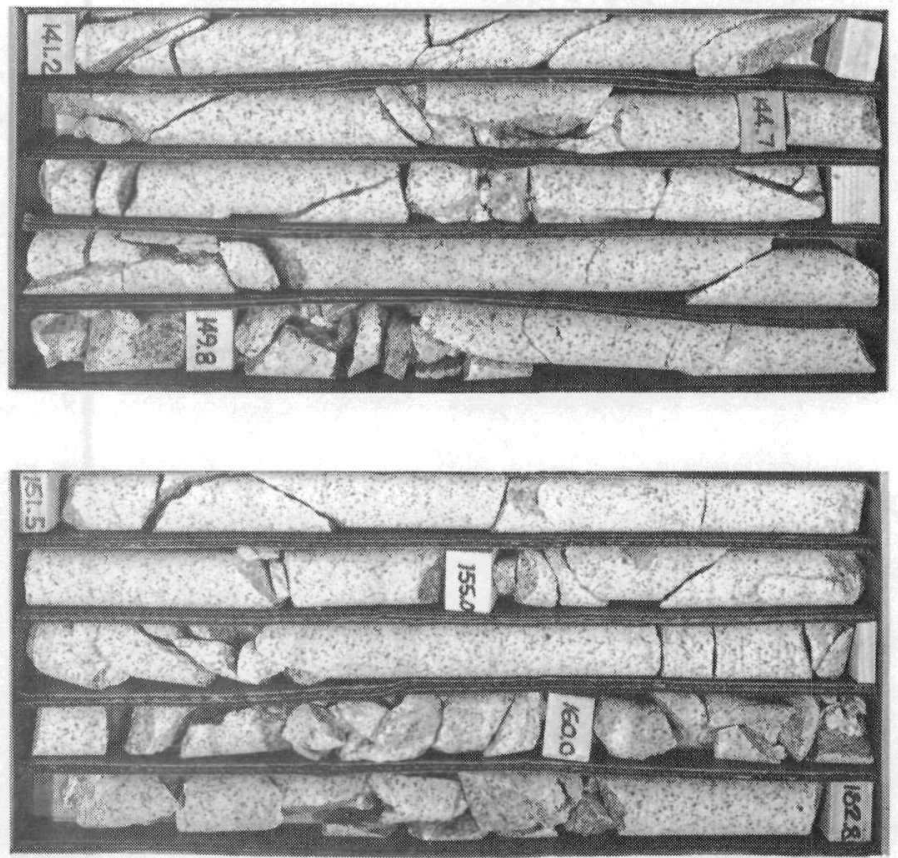

—159' Temporary loss of drilling fluid circulation
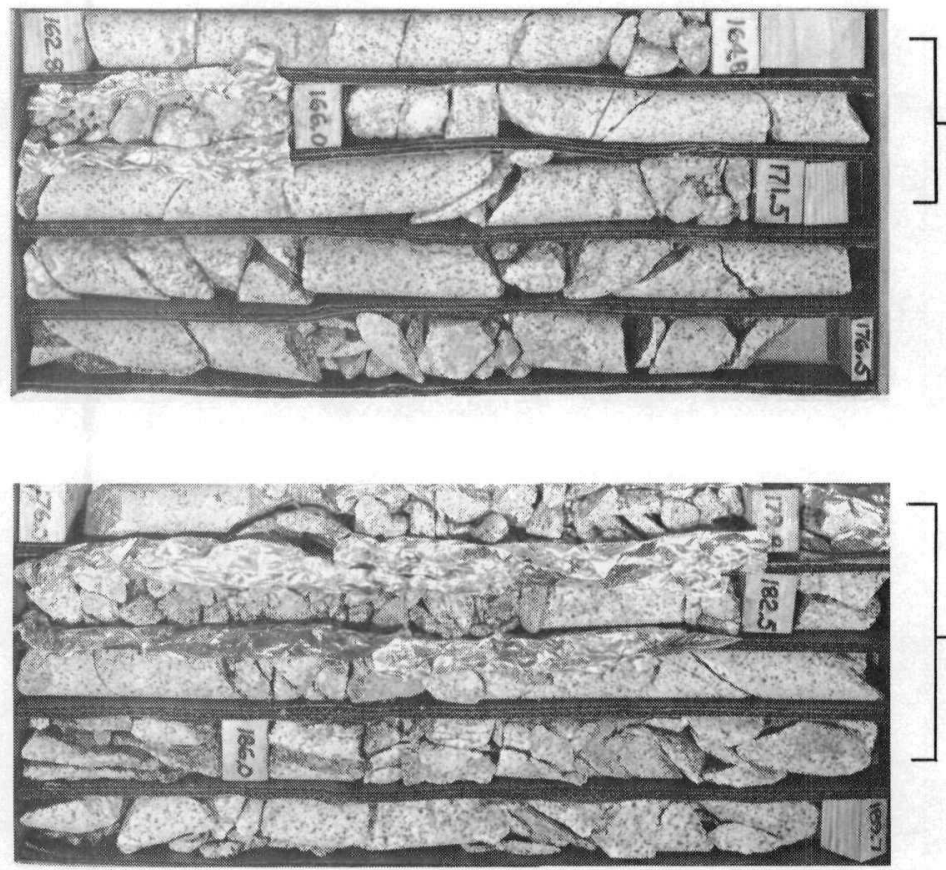

177-186' Shear zone. Core recovery $72 \%$ 
PS - 1

Depth in hole: $189.7-234.3 \mathrm{ft}$

Distance from shot point: $167-188 \mathrm{ft}$
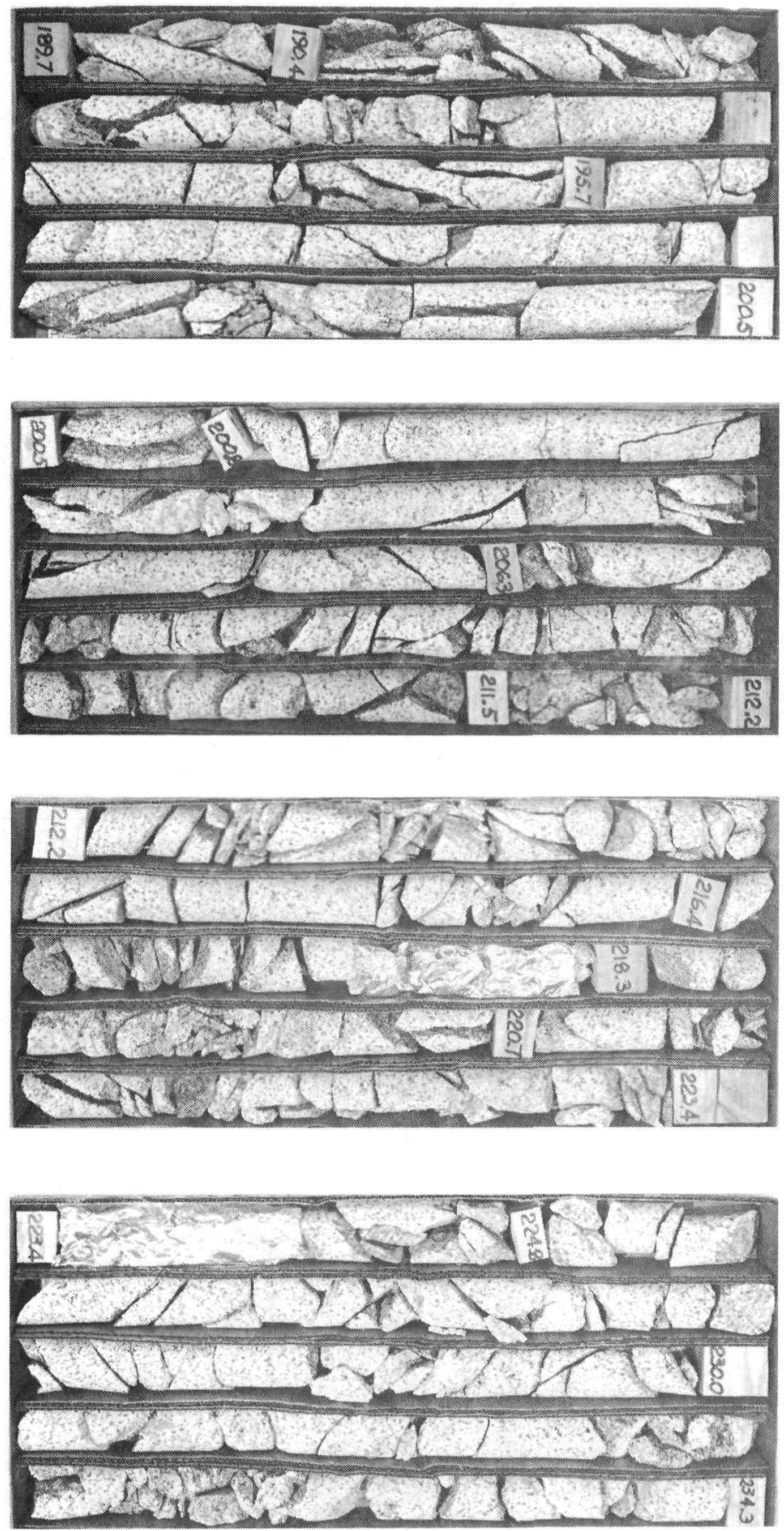
PS-1

Depth in hole: $234.3-283.5 \mathrm{ft}$

Distance from shot point: $160-167 \mathrm{ft}$
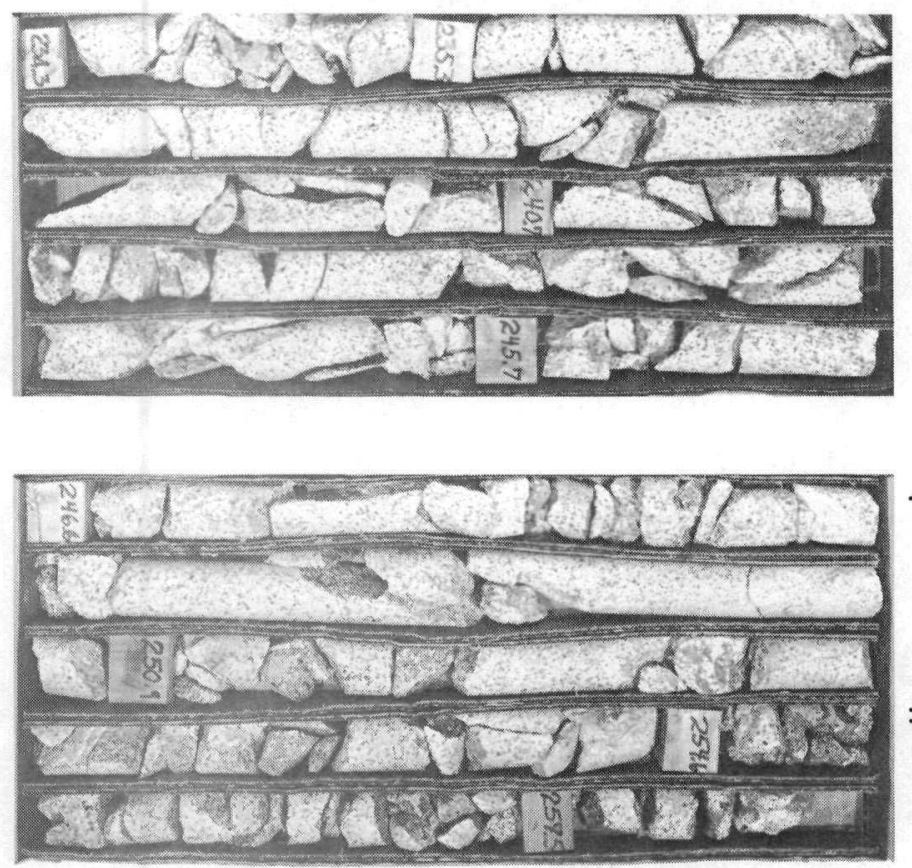

- $247-254^{\prime}$ Core recovery $96 \%$

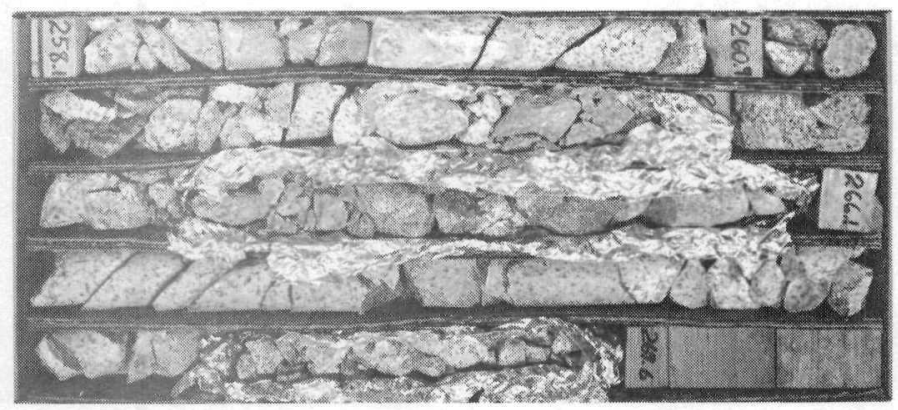

- 254-266' Core recovery $65 \%$
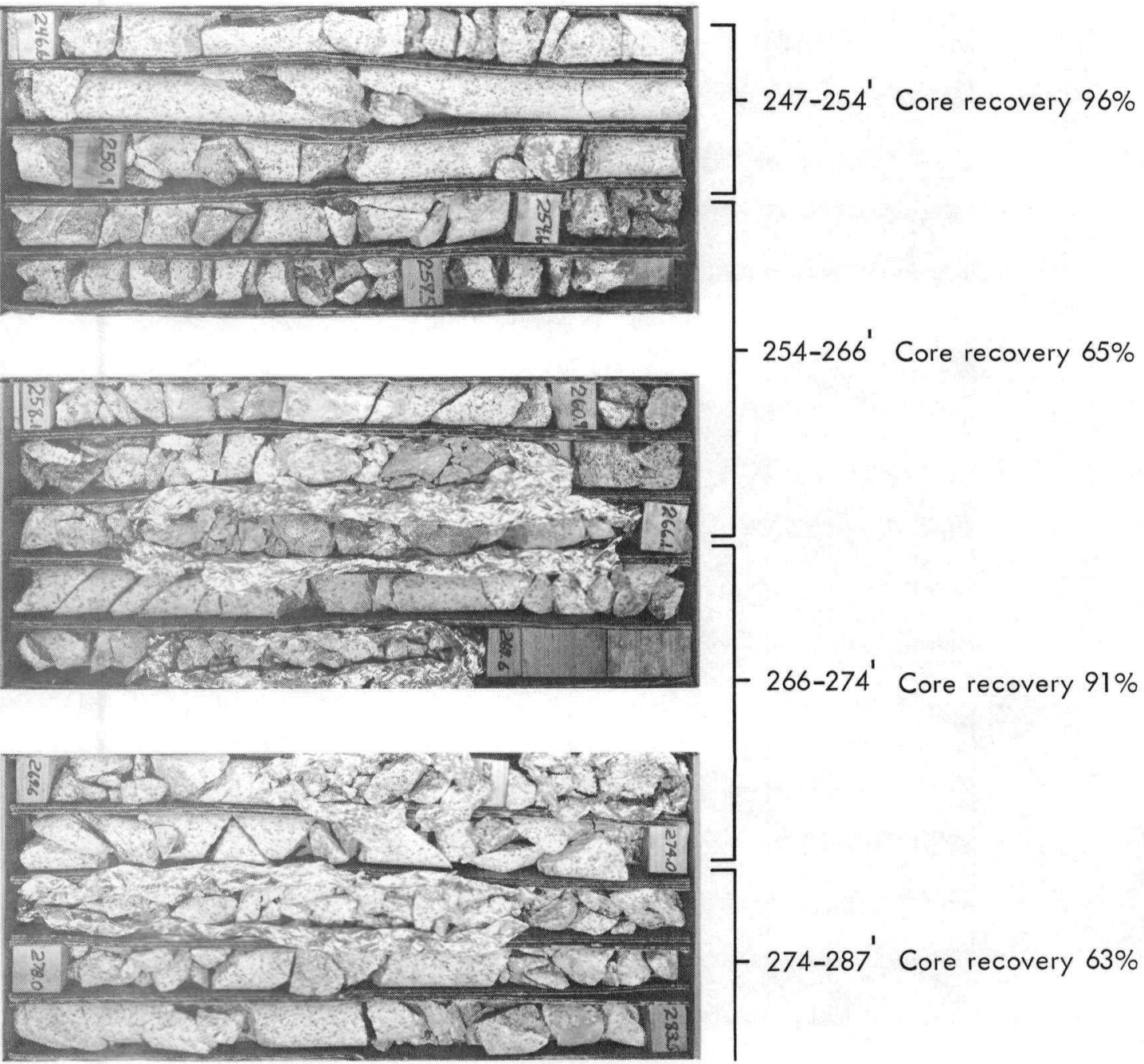

$266-274^{\prime}$ Core recovery $91 \%$

274-287' Core recovery $63 \%$ 
PS-1

Depth in hole: $283.5-326.2 \mathrm{ft}$

Distance from shot point: $160-168 \mathrm{ft}$

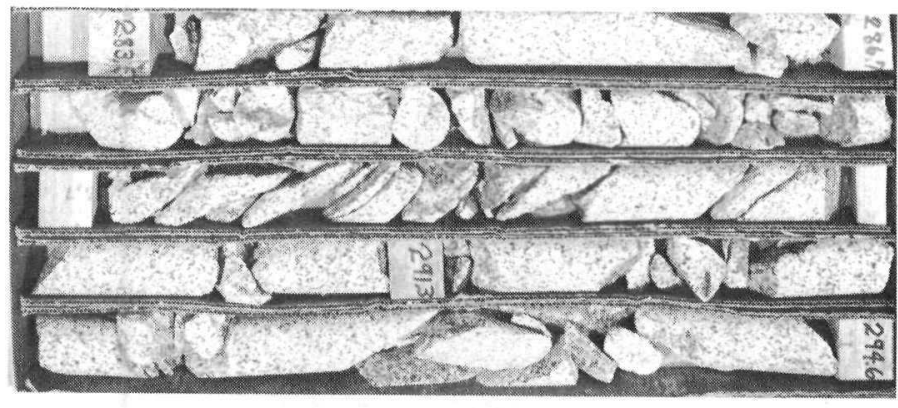

- $287.5^{\prime}$ Closest approach to shot point. $D=160^{\prime}$ postshot or $120^{\prime}$ preshot

287-297' Core recovery $96 \%$

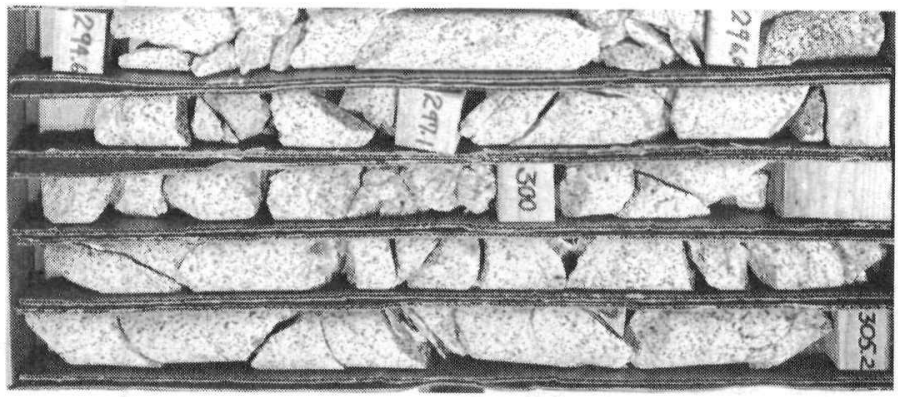

- 297-308' Core recovery $81 \%$

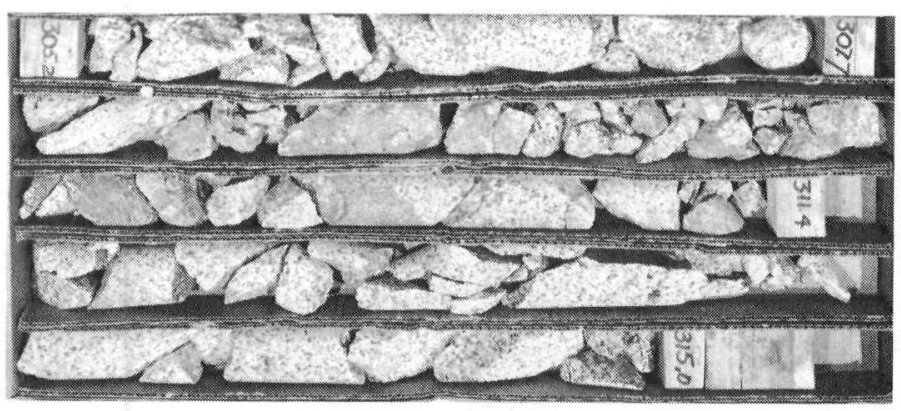

- 308-319' Core recovery $86 \%$

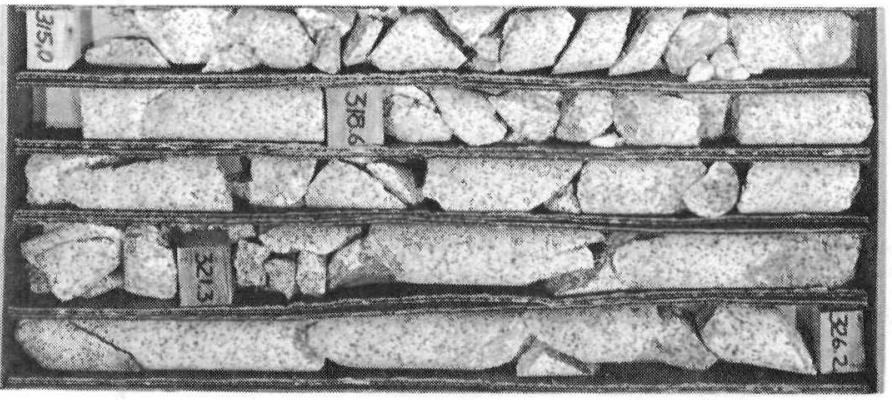

- 319-329' Core recovery $86 \%$ 
PS -1

Depth in hole: $326.2-365.2 \mathrm{ft}$

Distance from shot point: $168-183 \mathrm{ft}$

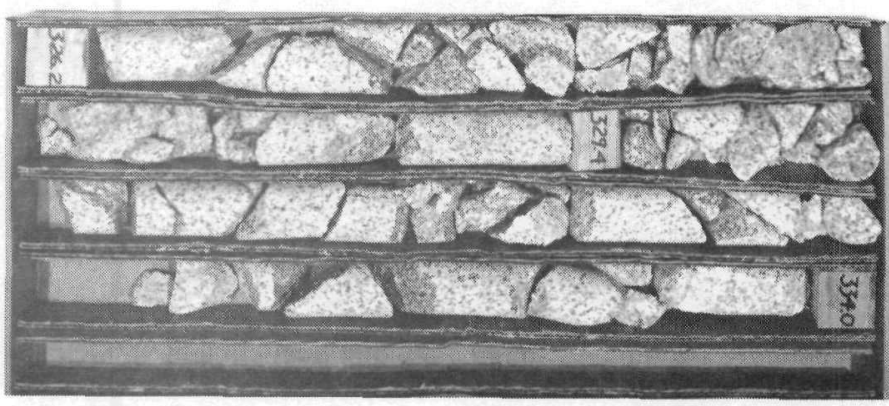

- 329-338' Core recovery $97 \%$
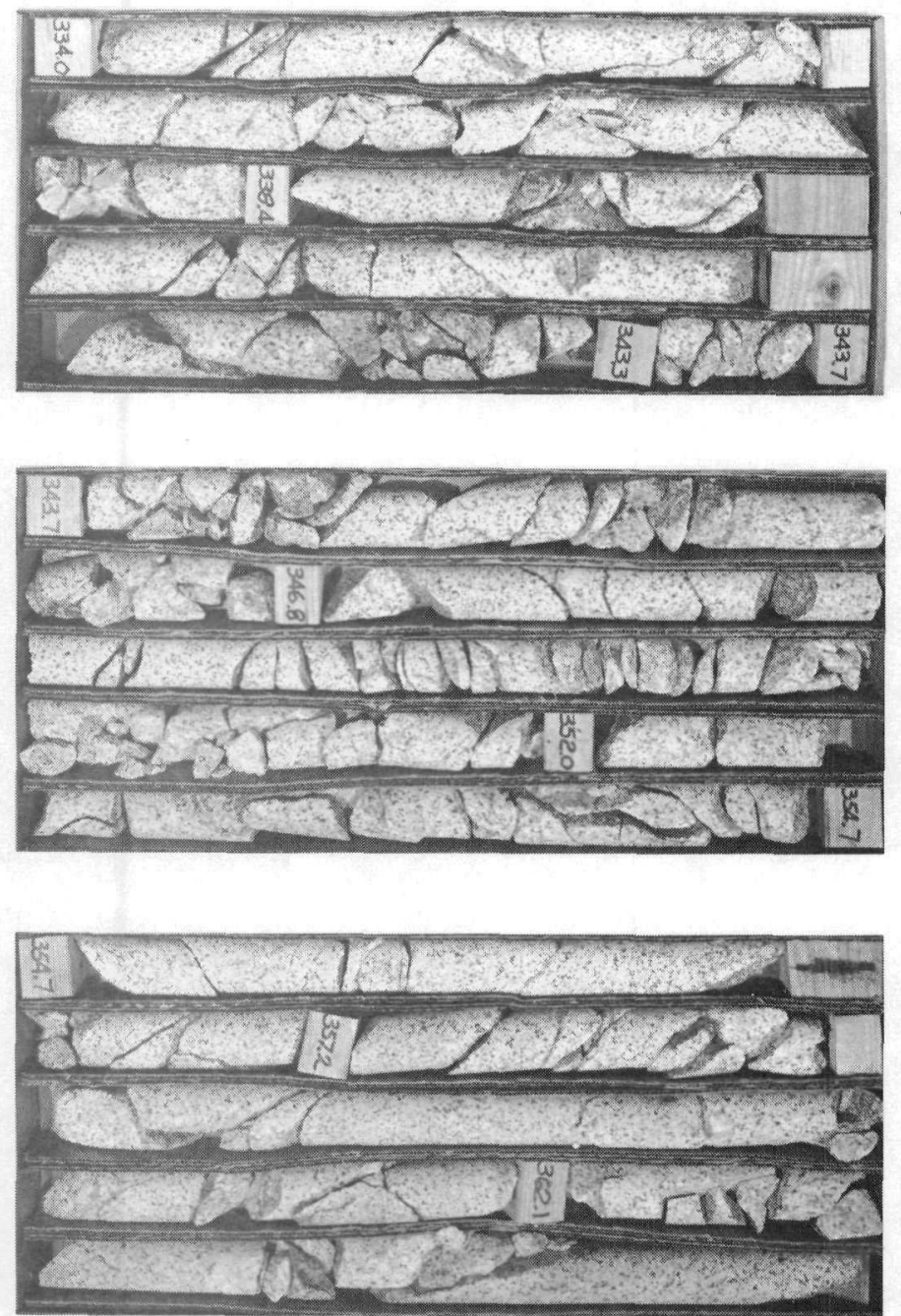
PS -1

Depth in hole: $365.2-410.4 \mathrm{ft}$

Distance from shot point: $183-203 \mathrm{ft}$

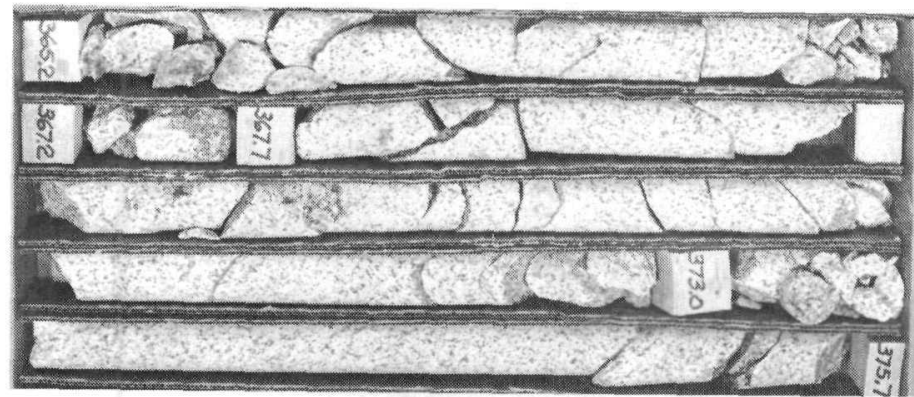

- 376' Temporary loss of drilling fluid circulation
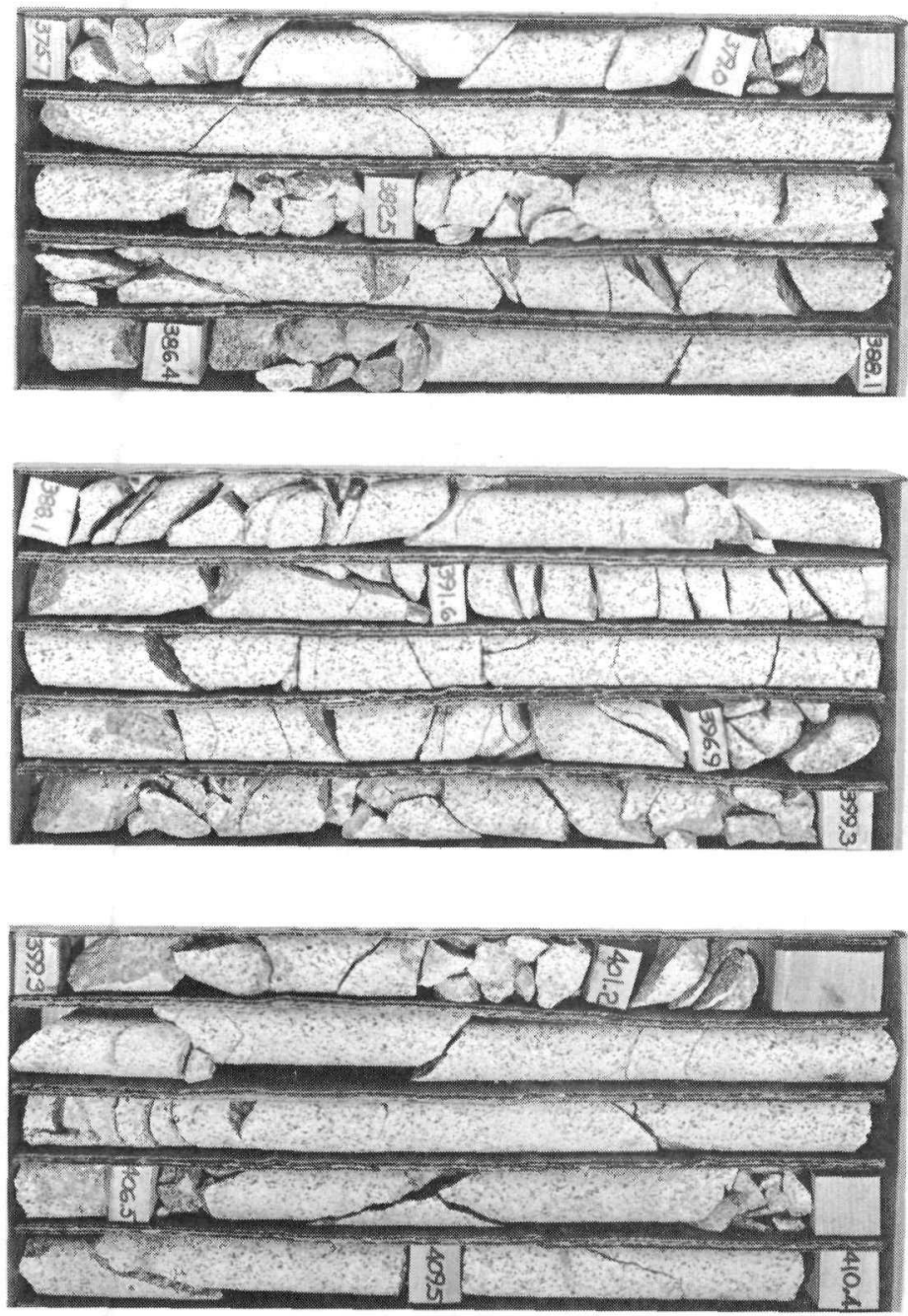
PS-1

Depth in hole: $410.4-423.8 \mathrm{ft}$

Distance from shot point: $203-213 \mathrm{ft}$
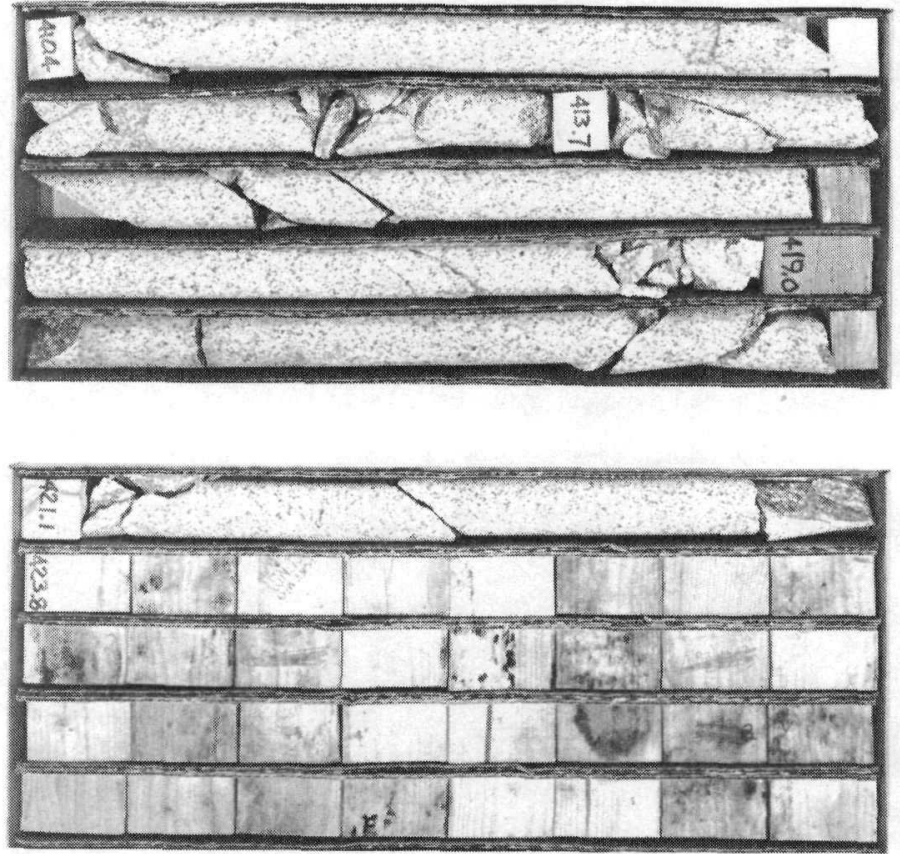


\section{Appendix 8 \\ Photographs of Cores from Hole U-15.01 PS-2}

Total depth $154.6 \mathrm{ft}$.

Overall core recovery $86.2 \%$. 
PS-2

Depth in hole : $0-57 \mathrm{ft}$

Distance from shot point: $340-374 \mathrm{ft}$
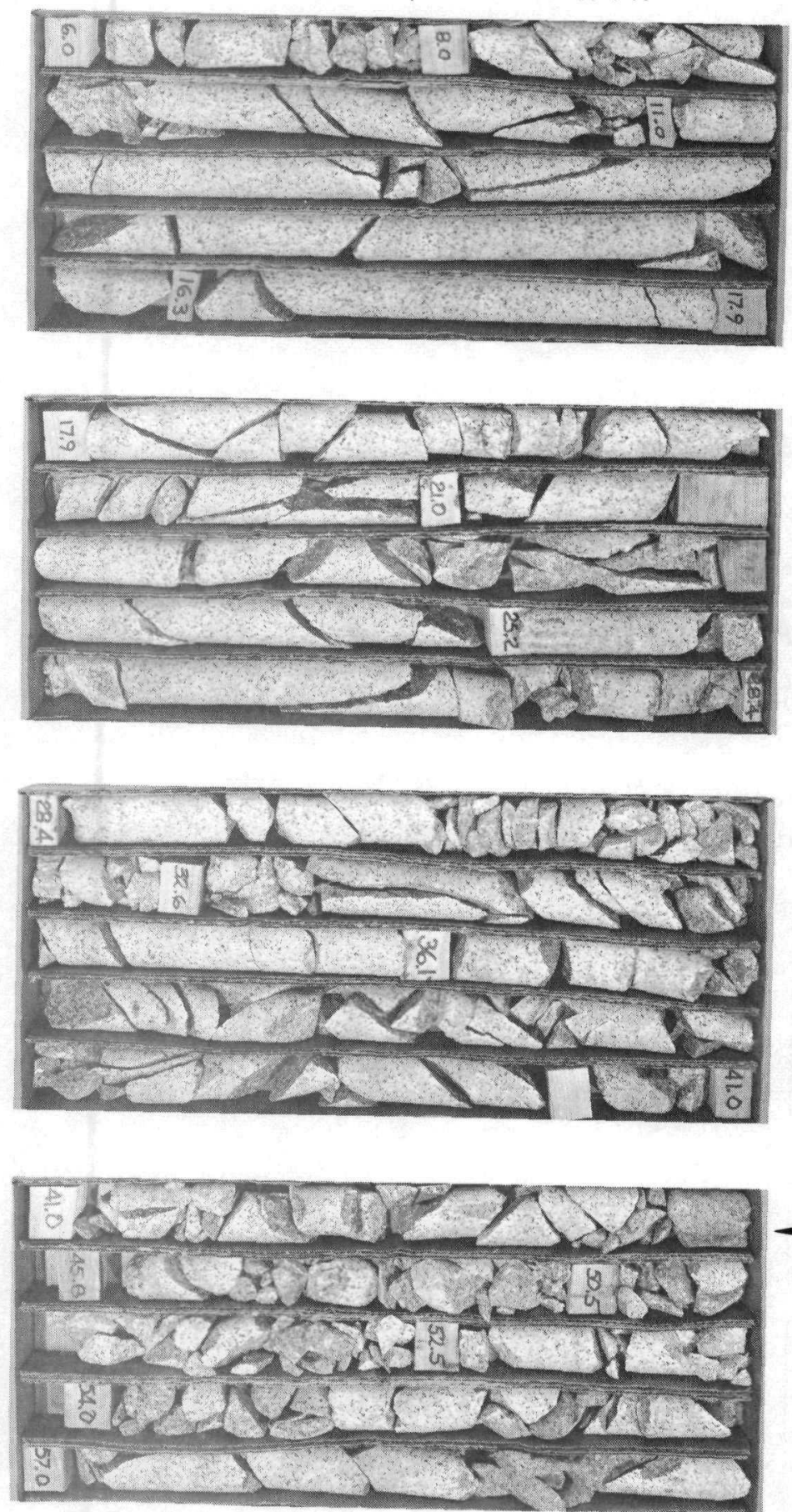

- $41^{\prime}$ Beginning. of shear zone 
PS-2

Depth in hole: $59.5-105.0 \mathrm{ft}$

Distance from shot point: $375-405 \mathrm{ft}$

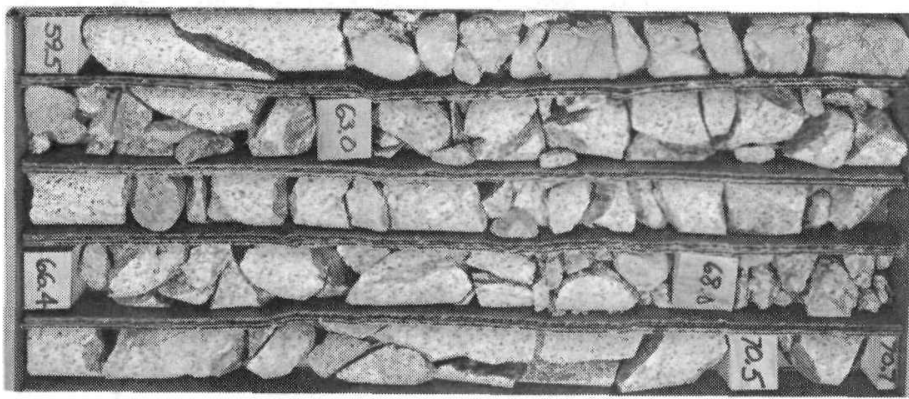

$\longleftarrow 69^{\prime}$ End of shear zone
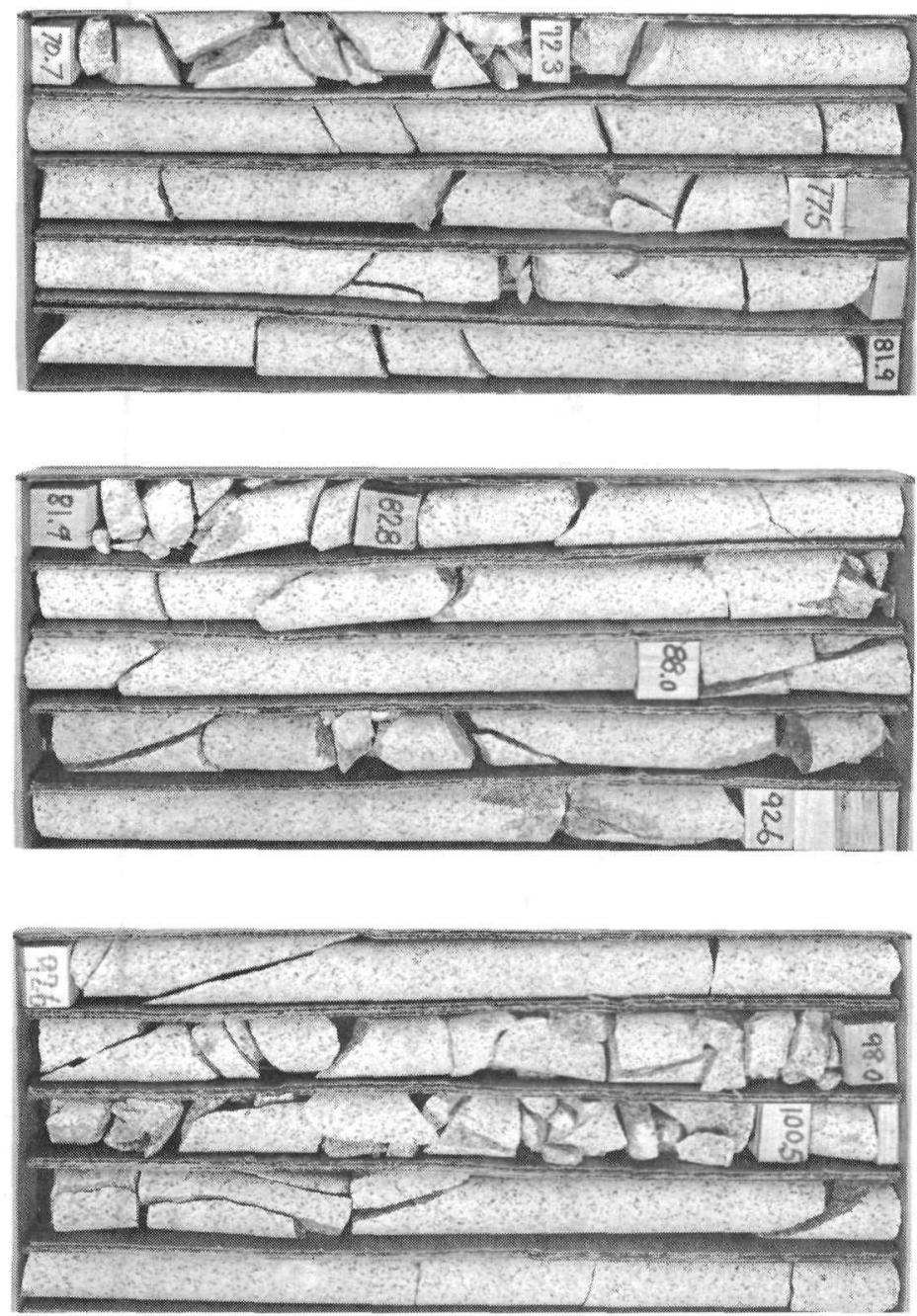
PS-2

Depth in hole: $105-150 \mathrm{ft}$

Distance from shot point: $405-438 \mathrm{ft}$
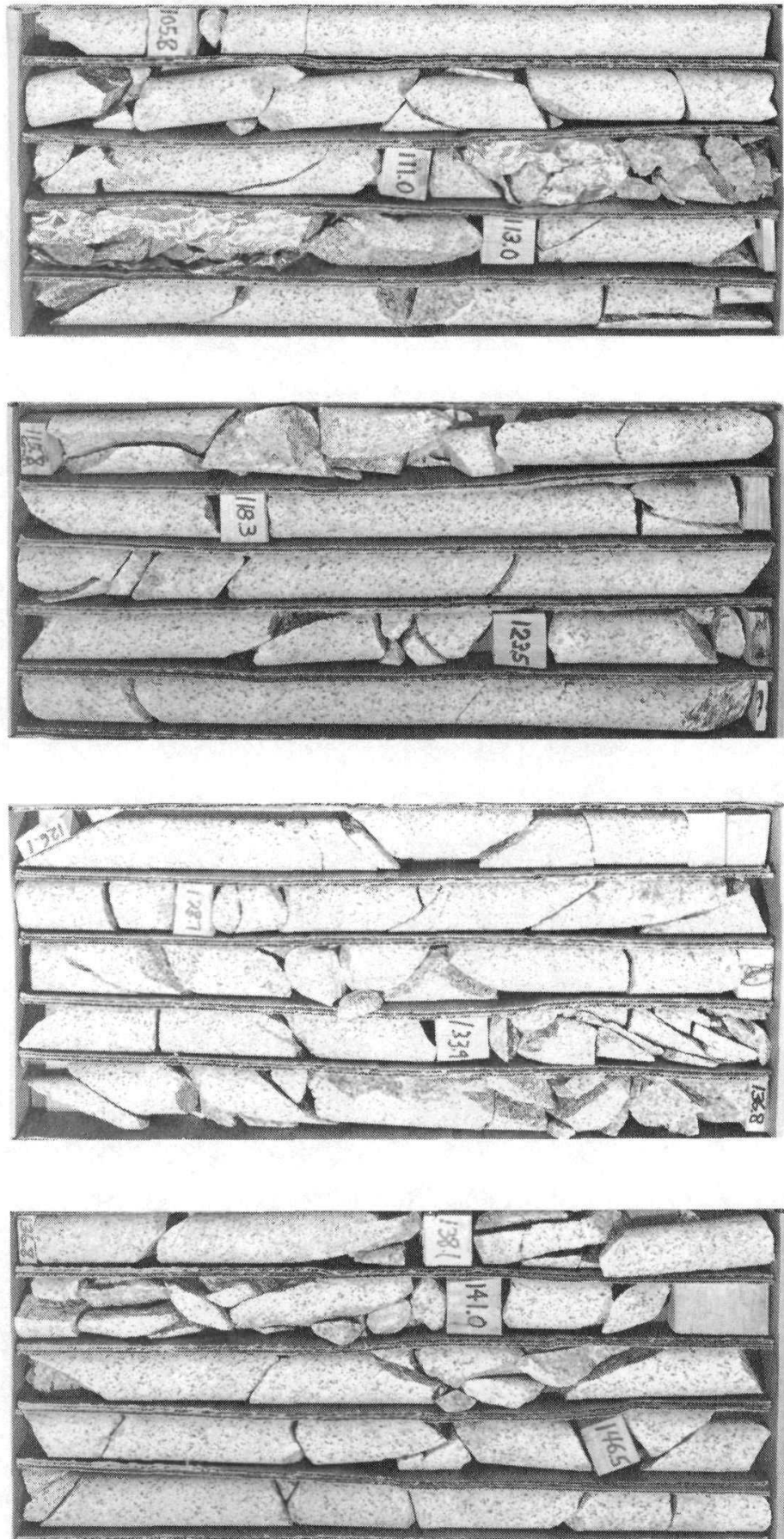
PS-2

Depth in hole: $150-154.6 \mathrm{ft}$

Distance from shot point: $438-440 \mathrm{ft}$

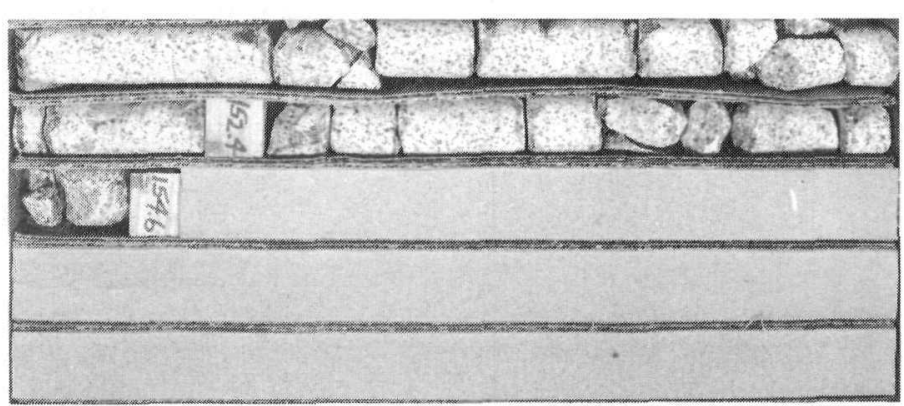




\section{Appendix 9 \\ Photographs of Cores from Hole U-15.01 PS-3}

Total depth $274.4 \mathrm{ft}$.

Overall core recovery $61.4 \%$. 
PS-3

Depth in hole: $0-86.0 \mathrm{ft}$

Distance from shot point: $250-330 \mathrm{ft}$

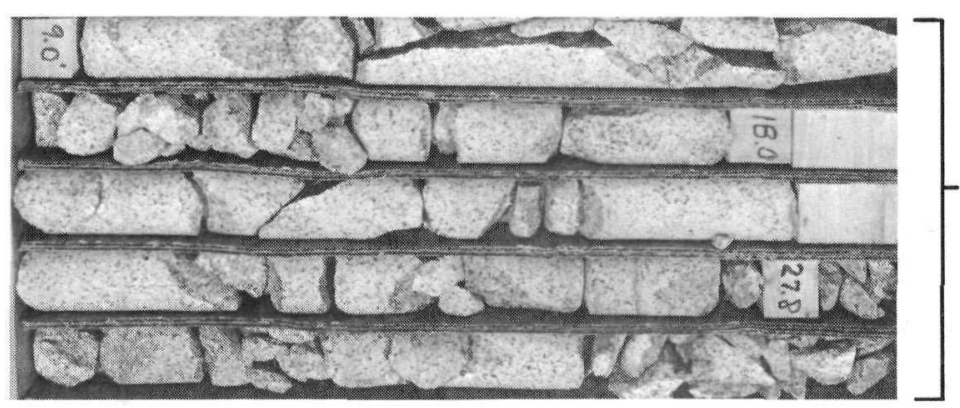

$-15-35^{\prime}$ Shear zone core recovery, $41 \%$
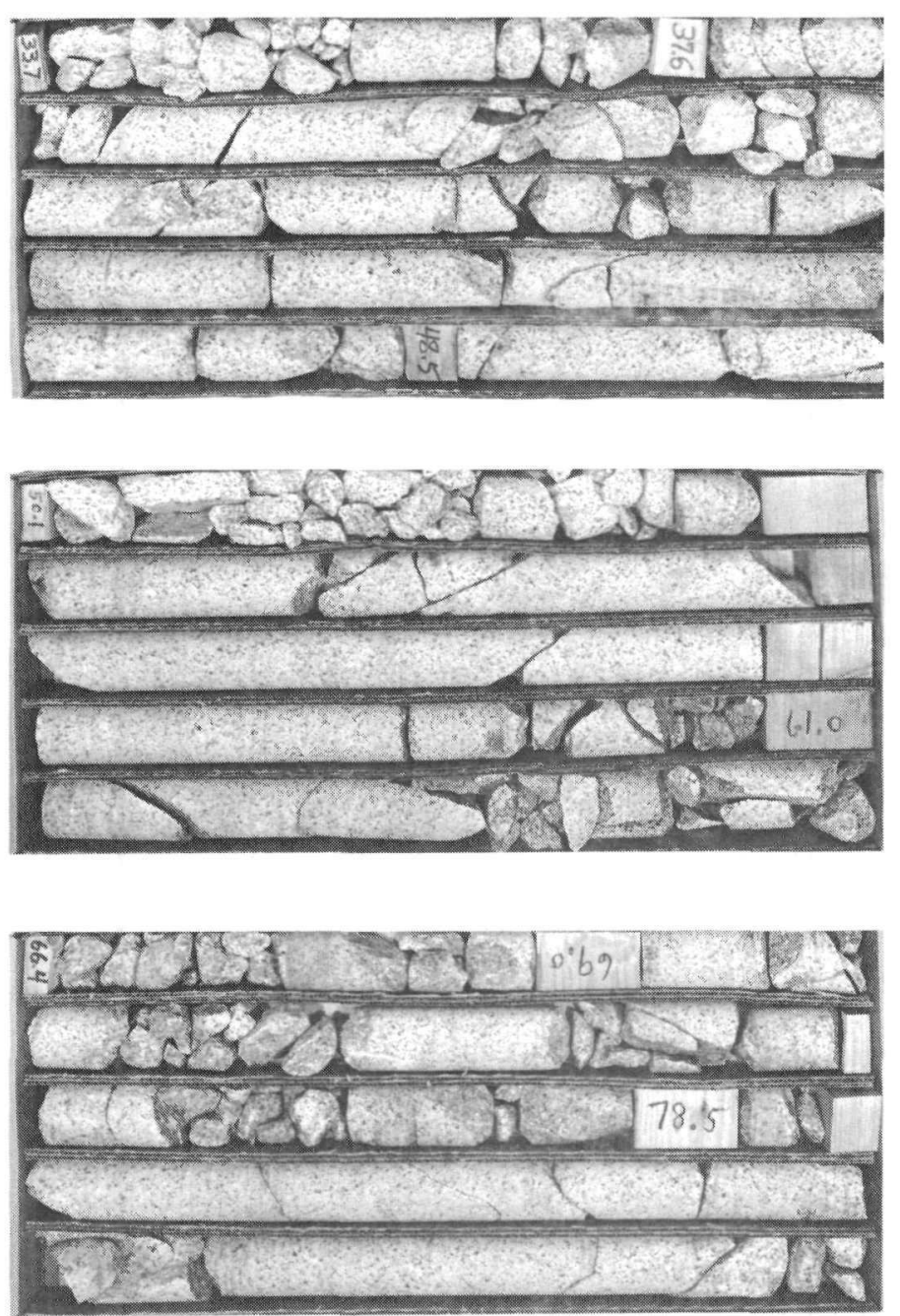
PS-3

Depth in hole: $86.0-152.0 \mathrm{ft}$

Distance from shot point: $194-250 \mathrm{ft}$

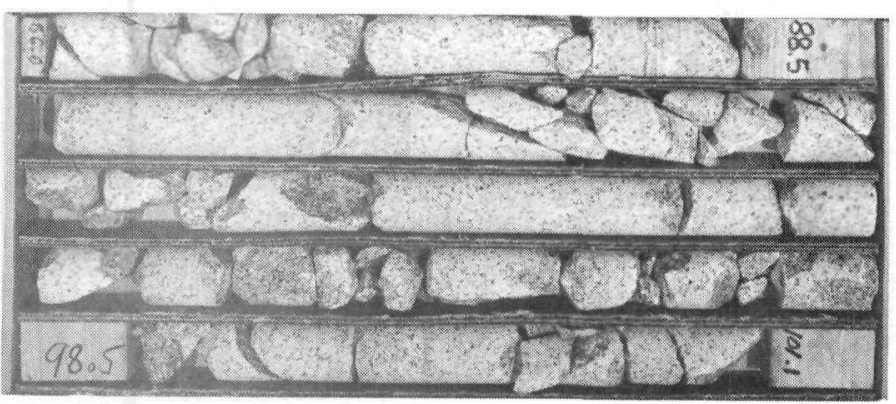

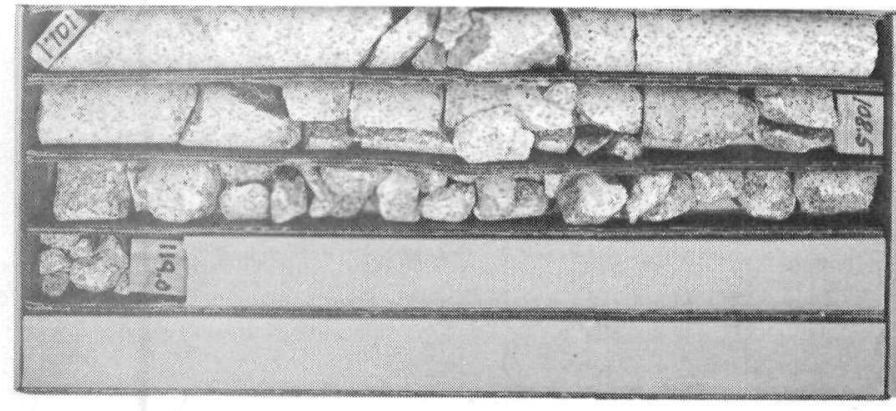

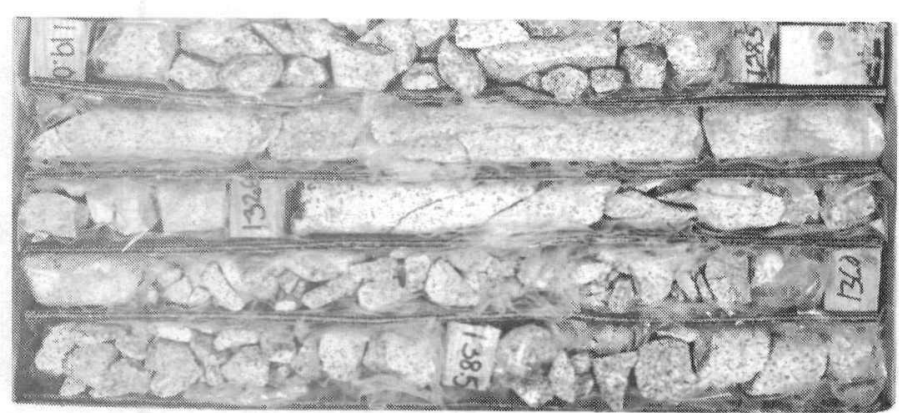

$-135^{\prime}$

- $115^{1}$ Temporary loss of drilling fluid circulation

-110-123' Shear zone. First detection of radioactivity $(0.6 \mathrm{mR}, \beta+\gamma$, 8-5-69). Core recovery $\sim 20 \%$

Permanent loss of drill fluid circulation. Spike in gamma log

$(<0.02 \mathrm{mR}, \beta+\gamma, 2-27-70)$

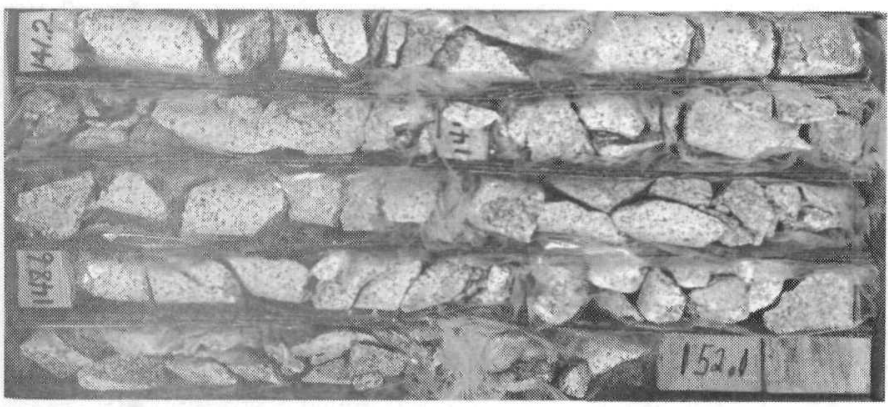


PS-3

Depth in hole: 152.0-191.0 ft

Distance from shot point: $165-194 \mathrm{ft}$

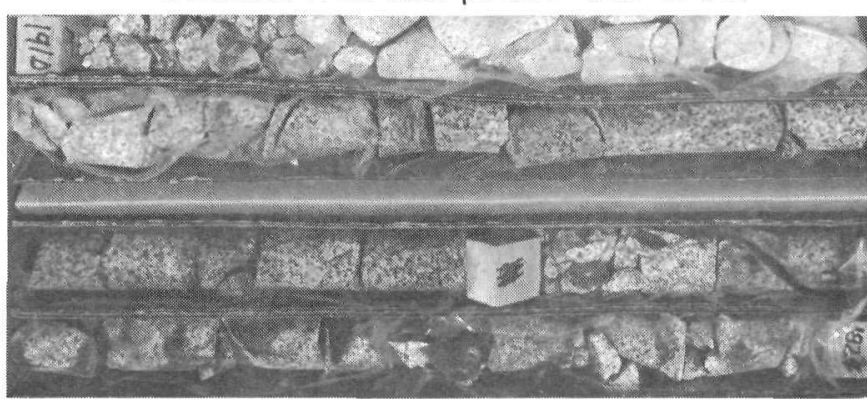

$\longleftarrow 162^{\prime} \quad \mathrm{T}=150^{\circ} \mathrm{C}, 8-19-69$

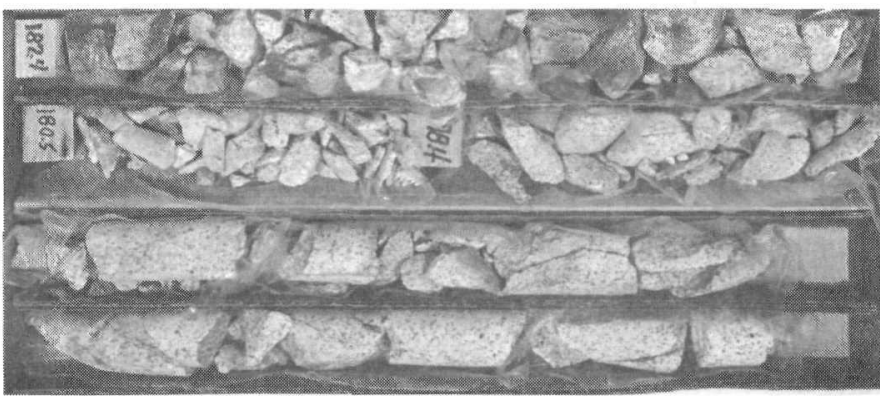

$\longleftarrow 164^{\prime}$ First glass encountered $(90 \mathrm{mR}$, $\beta+\gamma, 8-6-69$ )

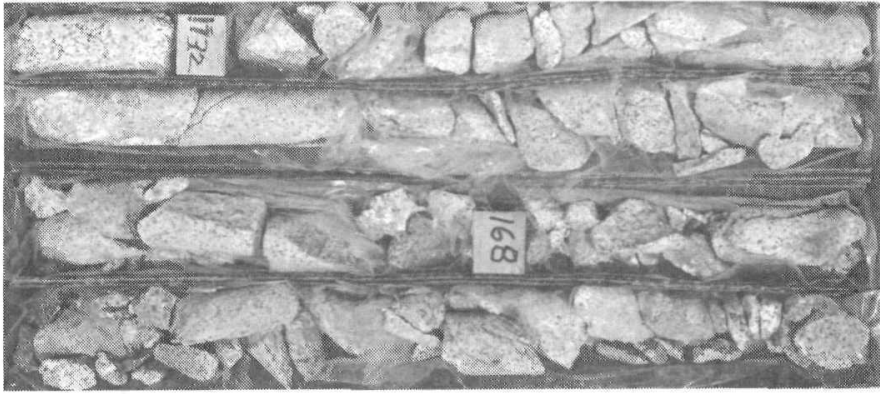

— 178-180.5' Granulation due to recovery technique (?)

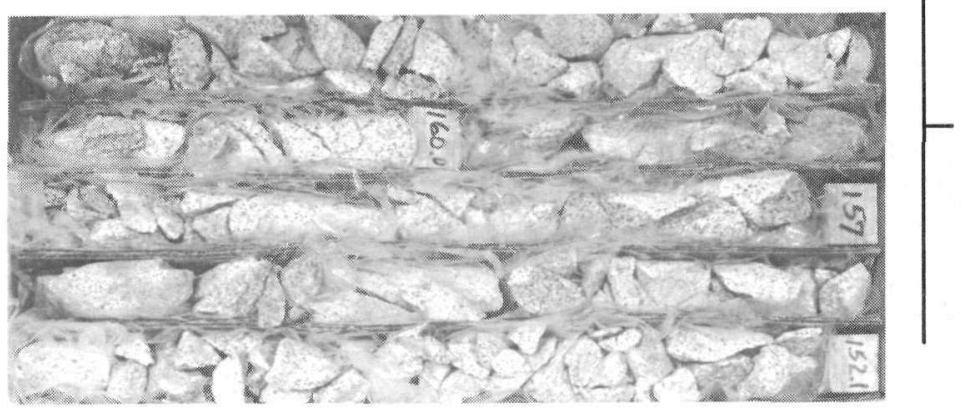

Discoloration (brown) from drilling mud 
PS-3

Depth in hole: 191.0-235.8 ft

Distance from shot point: $131-165 \mathrm{ft}$

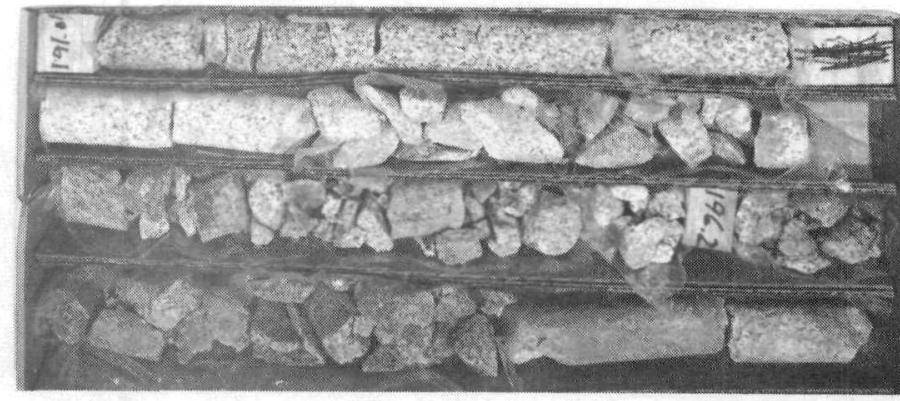

$\leftarrow 197^{\prime} \mathrm{T}=200^{\circ} \mathrm{C}, 8-19-69$

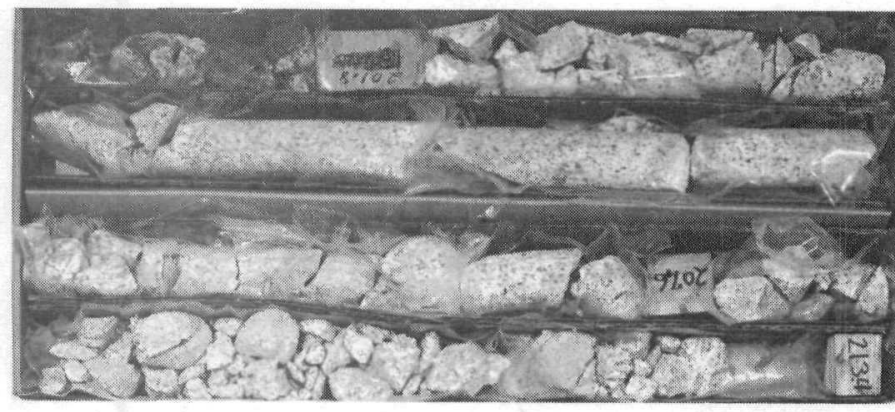

- Discoloration (brown) from drilling mud

$200^{\prime}$ Spike in gamma log $(0.5 \mathrm{mR}$, $\beta+\gamma, 2-27-70)$

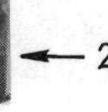
$210^{\prime}\left[\begin{array}{l}\mathrm{T}=204^{\circ} \mathrm{C}, 8-19-69 \text {. Beginning } \\ \text { of temperature plateau. Radio- }\end{array}\right.$ active glass in fractures $(20 \mathrm{mR}$, $[\beta+\gamma, 9-69)$

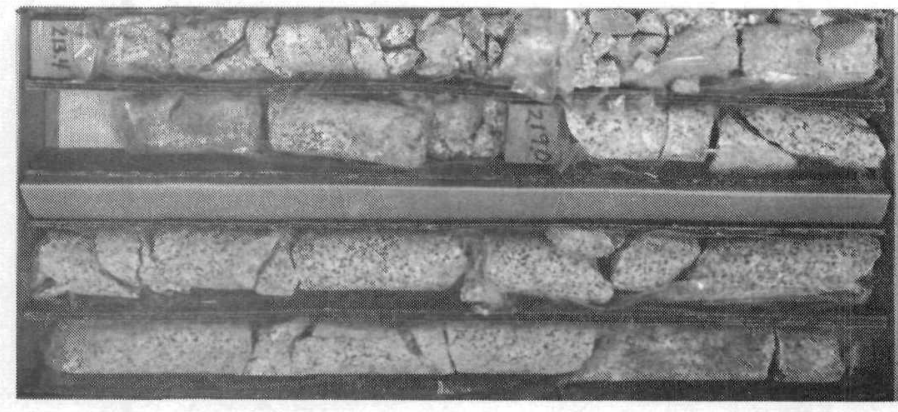

—214' Glass seam $(0.8 \mathrm{mR}, \beta+\gamma, 8-11-69)$
$-219^{\prime} \begin{aligned} & \text { Radioactive "sand" } \\ & (80 \mathrm{mR}, \beta+\gamma, 8-11-69)\end{aligned}$
—223' Glass seam $(0.1 \mathrm{mR}, \beta+\gamma, 2-27-70)$

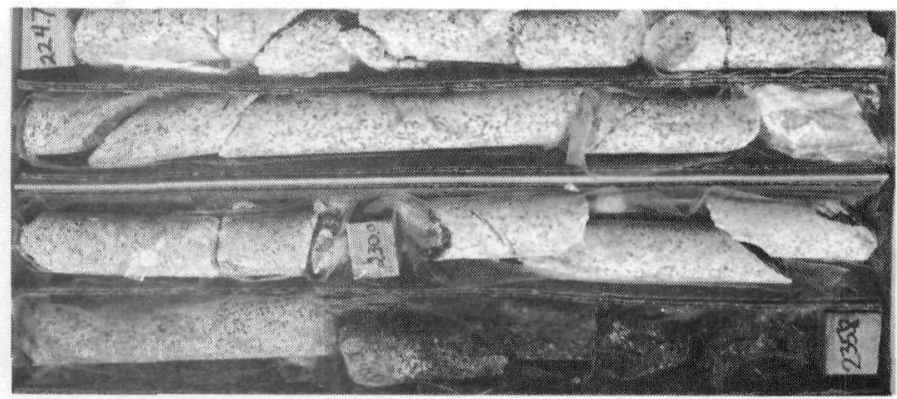

$\longleftarrow 226^{\prime}$ Glass seam

— 229' Onset of appreciable increase in 229 radioactivity 230 - Glass seams, $150 \mathrm{mR}, \beta+\gamma, 8-11-69$ $233^{\prime}$ Chimney boundary, 200mR, $\beta+\gamma$, 8-11-69. Vesicular, glassy matrix 
PS-3

Depth in hole: $235.8-274.4 \mathrm{ft}$

Distance from shot noint: 112-131 ft

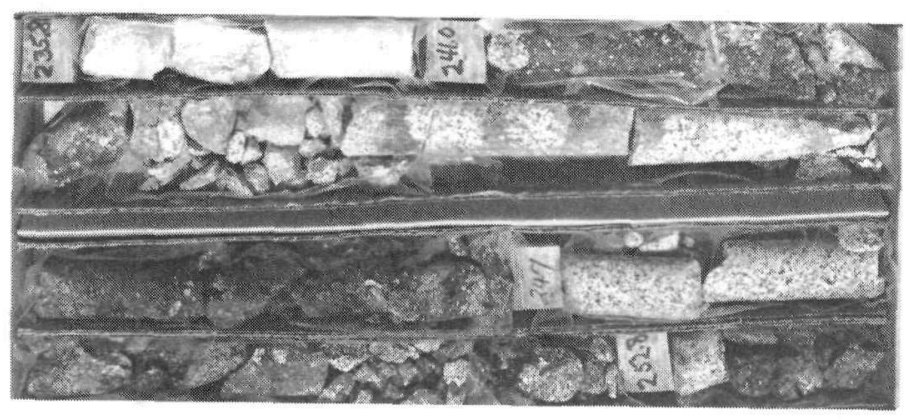

$=237^{\prime}$ Aplite dike (3mR, $\left.\beta+\gamma, 8-11-69\right)$. Dull black rock, not glassy, partially absorbed spall

241-247' 190mR, $\beta+\gamma, 8-11-69$

$246^{\prime}$ Partially absorbed spall in black, vesicular, glassy matrix

- 253' Vesicular, glassy

(150mR, $\beta+\gamma, 8-11-69)$

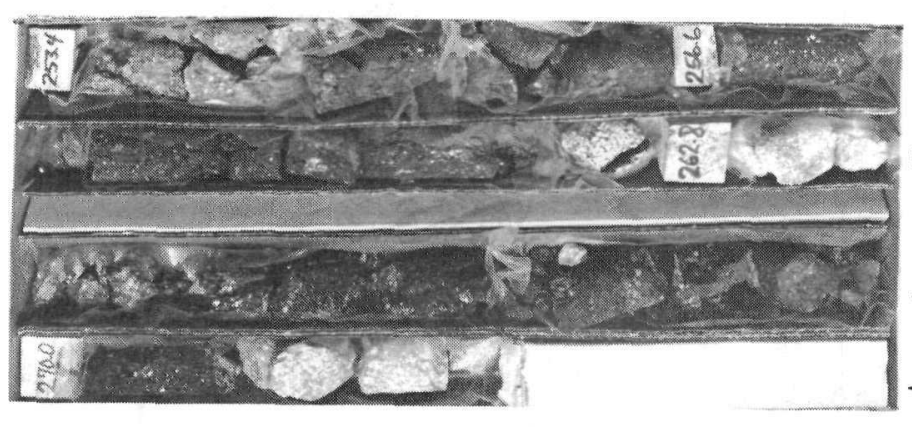

Glassy seams in slightly
$-253-263^{\prime}$ vesicular matrix (200mR,
$\beta+\gamma, 8-12-69)$
$258^{\prime}$ Vesicular, dull, low-Si melt (?)
$263-270^{\prime}$ Partially absorbed spall
Epidote (?)
$(160 \mathrm{mR}, \beta+\gamma, 8-12-69)$
$-270^{\prime}$ Glassy, vesicular $(150 \mathrm{mR}, \beta+\gamma$
$8-12-69)$

(All $\beta+\gamma$ readings are on contact) 
1. D. D. Rabb, Size Distribution Study of Piledriver Particles, Lawrence Radiation Laboratory, Livermore, Rept. UCRL-50489 (1968).

2. C. R. Boardman, Results of an Exploration into the Top of the Piledriver Chimney, Lawrence Radiation Laboratory, Livermore, Rept. UCRL-50385 (1967).

3. T. S. Sterrett, Drilling Investigation of the Lower Part of the Piledriver Cavity, Lawrence Radiation Laboratory, Livermore, Rept. UCRL-50765 (1969).

4. C. J. Distephano (Project Director), D. R. Williams, and H. A. Jack, Experiments in Rock Bolting, Operation Flintlock, Shot Piledriver (U), POR-4015 (WT-4015)(1969) (SRD).

5. John W. Allingham and I. Zietz, "Geophysical Data on the Climax Stock, NTS, Nye, Nevada," Geophysics 28, 599 (1962).

6. F. N. Houser and F. G. Poole, Age Relations of the Climax Composite Stock, NTS, Nye Co., Nevada, USGS Professional Paper 424-B, 176-7 (1961).

7. F. N. Houser and F. G. Poole, Summary of Physical and Chemical Nature of Granitic Rocks at the U-15a Site, Climax Stock, NTS, USGS Tech. Letter, Area 15-1 (1961).

8. H. Perla, Plot Plan and Geologic Section, NTS Area 15 Project Piledriver Station 1501, 015-1501-C4, USAEC Nevada Operations Office (1964).

9. D. Rabb, Lawrence Radiation Laboratory, Livermore, personal communication (1970).

10. W. R. Perrett (Project Officer), Free Field Ground Motion in Granite, Operation Flintlock, Shot Piledriver, POR-4001 (WT-4001) (1968).

11. C. T. Vincent (Project Officer) and J. Rempel, Close-in Stress Measurements, Operation Flintlock, Shot Piledriver (U), POR-4003 (WT-4003) (1968) (CFRD).

12. P. Lieberman (Project Officer), Pressure-Time Measurements in Granite, Operation Flintlock, Shot Piledriver (U), POR-4002 (WT-4002) (1967) (CRD).

13. J. T. Cherry and E. G. Rapp, Calculation of Free-Field Motion for the Piledriver Event, Lawrence Radiation Laboratory, Livermore, Rept. UCRL-50373 (1968).

14. J. L. Merritt, Technical Director's Summary Report, Operation Flintlock, Shot Piledriver (U), POR-4017 (WT-4017) (1969), pp. 25, 32, 37 (SRD).

15. H. H. Holmes (Project Officer), H. M. Hansen, and A. O. Bracket, Structural Response Measurements, Operation Flintlock, Shot Piledriver (U), POR-4010 Vol. 3 (WT-4010 Vol. 3) (1969) (CRD).

16. H. V. Hoffman and F. M. Sauer (Project Officer), Free-Field and Surface Motions, Operation Flintlock, Shot Piledriver, POR-4000 (WT-4000) (1969).

17. H. L.Smith (Project Officer), Tunnel Photography, Operation Flintlock, Shot Piledriver, POR-4012 (WT-4012) (1969). 
18. C. J. Distephano (Project Officer) and L. J. Ashbaugh, Instrumentation of Tunnel Liners, Passive Instrumentation, Operation Flintlock, Shot Piledriver (U), POR-4010 Vol. 4 (WT-4010 Vol. 4) (1969) (CRD).

19. T. R. Butkovich, Rock Melted per Kiloton Energy Yield, Lawrence Radiation Laboratory, Livermore, internal document UOPKL-68-10 (1968).

20. T. R. Butkovich, The Gas Equation of State for Natural Materials, Lawrence Radiation Laboratory, Livermore, Rept. UCRL-14729 (1967).

21. P. J. Closmann, "On the Prediction of Cavity Radius Produced by an Underground Nuclear Explosion," J. Geophys. Res. 74, 3935 (1969).

22. G. H. Higgins and T. R. Butkovich, Effect of Water Content, Yield, Medium, and Depth of Burst on Cavity Radii, Lawrence Radiation Laboratory, Livermore, Rept. UCRL-50203 (1967).

23. C. E. Chapin, Cavity Pressure History of Contained Nuclear Explosions, Lawrence Radiation Laboratory, Livermore, Rept. UCRL-72140 (1969).

24. H. C. Heard and F. J. Ackerman, Prediction of Cavity Radii From Underground Nuclear Explosions (U), Lawrence Radiation Laboratory, Livermore, Rept. UCRL-50324 (1967) (SRD).

25. S. Derlich and F. Supiot, Phénomenologie Génerale des Explosions Nucléaires Souterraines, CEA-R-3750 (1969).

26. L. Michaud, Explosions Nucléaires Souterraines Etude des Rayons de Cavité, CEA-R-3594 (1968).

27. R. D. McArthur and J. B. Misz, Geology of the Granite Site, Area 15, NTS, Preliminary Rept. GN-7-60 (1960).

28. W. E. Bowers and W. L. Emerick, Supplementary Geologic Mapping in the 1500 Reentry Tunnel, Area 15, NTS, Nye Co., Nevada, USGS Tech. Letter, Area 15-4 (1963).

29. R. E. Goodman, Effects of Joints on the Strength of Tunnels, Research on Rock Bolt Reinforcement, Omaha District, Corps of Engineers, Dept. of Army, Rept. 5 (1968).

30. W. L. Emerick, R. P. Snyder, and W. E. Bowers, Summary of Post-Shot Geologic Effects in the 1500 Tunnel, Area 15, NTS, Nye Co., Nevada, USGS Tech. Letter, Area 15-3 (1962).

31. F. N. Houser and W. L. Emerick, Preliminary Structural Analysis of ExplosionProduced Fractures, Hardhat Event, Area 15, NTS, USGS Professional Paper 501-C, 100-200 (1964).

32. D. Griggs and J. Handin, "Observations on Fracture and a Hypothesis of Earthquakes," in Rock Deformation (D. Griggs and J. Handin, Eds.), G.S.A. Memoir 79, p. 349 (1960).

33. H. C. Heard, The Influence of Environment on the Inelastic Behavior of Rocks, Lawrence Radiation Laboratory, Livermore, Rept. UCRL-72164 (1969).

34. N. Short, "Effects of Shock Pressures from a Nuclear Explosion on Mechanical and Optical Properties of Granodiorite," J. Geophys. Res. 71, 1195 (1966). 
35. S. Derlich, "Underground Nuclear Explosion Effects in Granite Rock Fracturing," paper presented at ANS Topical Meeting on Engineering with Nuclear Explosives, Las Vegas, Nevada, Jan. 14-16, 1970.

36. F. D. Bloss, "Anisotropy of Fracturing in Quartz," Am. J. Sci. 255, 214 (1957).

37. F. A. Donath, "Experimental Study of Shear Failure in Anisotropic Rocks," Bull. Geol. Soc. Am. 72 , 985 (1961).

38. A. E. Lewis, Chemical Mining of Primary Copper Ores by Use of Nuclear Technology, Lawrence Radiation Laboratory, Livermore, Rept. UCRL-72159, preprint of paper presented at ANS Topical Meeting on Engineering with Nuclear Explosives, Las Vegas, Nevada, Jan. 14-16, 1970.

39. A. B. Gibbons, E. N. Hinrichs, D. D. Dickey, F. A. McKeown, F. G. Poole, and F. N. Houser, Engineering Geology of Test Sites in Granite and Dolomite at Gold Meadows, Climax and Dolomite Hill, NTS, Nye Co., Nevada, USGS Trace Elements Memorandum Report 884 (1959).

40. G. A. Izett, "Granite" Exploration Hole, Area 15, NTS, Nye Co., Nevada, Interim Report Part C, Physical Properties, USGS Trace Elements Memorandum Report $836-\mathrm{C}(1960)$. 


\section{Distribution}

LRL Internal Distribution

Michael M. May

R. E. Batzel

A. Biehl

A. C. Haussmann

C. A. McDonald

W. E. Nervik

H. L. Reynolds/P. E. Coyle

J. W. Rosengren

E. Teller

G. C. Werth

J. E. Carothers

L. Crooks/E. Harp

D. W. Dorn

G. D. Dorough

F. S. Eby

E. H. Fleming

W. B. Harford

G. H. Higgins

F. Holzer

A. E. Lewis

J. T. Cherry

J. S. Kane

J. B. Knox

M. D. Nordyke

W. E. Vandenberg

T. Perlman

P. H. Moulthrop

J. Toman

B. Rubin

P. C. Stevenson
L. D. Ramspott

I. Y. Borg

D. O. Emerson

D. D. Rabb

W. C. Grayson

C. E. Chapin

R. L. Braun

J. L. Moore

R. Quong

R. Schock

D. R. Stephens

H. C. Heard

C. J. Sisemore

J. W. Hadley

T. Butkovich

R. W. Taylor

R. McArthur, Mercury

TID Berkeley

TID File

External Distribution

C. Boardman

CER Geonuclear Corp.

Las Vegas, Nevada

T. Sterrett

El Paso Natural Gas Co.

El Paso, Texas

TID-4500 Distribution, UC-35, Nuclear Explosions Peaceful Applications

$\mathrm{WC} / 1 \mathrm{c} / 1 \mathrm{p}$ 